Pontifícia Universidade C $_{\text {atólica }}$

Gláucia Mendes Oliveira Silvestre

\title{
A Educação Metodista e seus Modelos Pastorais
}

Dissertação de Mestrado

Dissertação apresentada como requisito parcial para obtenção do grau de Mestre pelo Programa de Pós-graduação em Teologia do Departamento de Teologia da PUC-Rio.

Orientador: Prof. Luis Corrêa Lima

Rio de Janeiro

Setembro de 2014 


\section{Gláucia Mendes Oliveira Silvestre}

\section{A Educação Metodista e seus Modelos Pastorais}

Dissertação apresentada como requisito parcial para obtenção do grau de Mestre pelo Programa de Pós-Graduação em Teologia do Departamento de Teologia da PUC-Rio. Aprovada pela Comissão Examinadora abaixo assinada.

Prof. Luis Corrêa Lima

Orientador

Departamento de Teologia - PUC-Rio

Prof. Levy Bastos Curso de Teologia - Igreja Metodista RJ

Prof. Abimar Moraes de Oliveira Departamento de Teologia - PUC-Rio

Denize Berruezo Portinari

Coordenadora Setorial de Pós-Graduação e Pesquisa do

Centro Teologia e Ciências Humanas - PUC-Rio

Rio de Janeiro, 02 de setembro de 2014 
Todos os direitos reservados. É proibida a reprodução total ou parcial do trabalho sem a autorização da universidade, da autora e do orientador.

\section{Gláucia Mendes Oliveira Silvestre}

Graduou-se em Teologia no Seminário César Dacorso Filho, da Igreja Metodista em 1995. Cursou Sistema de Integralização em Teologia no Centro Universitário Metodista Bennett em 2005/2006. Desenvolveu trabalho na Pastoral Escolar e Universitária do Instituto Metodista Bennett durante 15 anos (1998-20013), dentre os quais coordenou o setor por 11 anos. Exerce as funções pastorais, com nomeação episcopal desde 1993 até os dias atuais. Participou de diversos congressos na área de Pastoral e Capelania Escolar.

\section{Ficha Catalográfica}

Silvestre, Gláucia Mendes Oliveira.

A educação metodista e seus modelos pastorais de educação / Gláucia Mendes Oliveira Silvestre; orientador: Luis Corrêa Lima. - Rio de Janeiro PUC, Departamento de Teologia, 2014.

v., 151 f. : il. (color.) ; $30 \mathrm{~cm}$

1. Dissertação (mestrado) - Pontifícia Universidade Católica do Rio de Janeiro, Departamento de Teologia, 2014.

Inclui referências bibliográficas.

1. Teologia - Teses. 2. Movimento metodista. 3. Teologia da educação metodista. 4. História do metodismo. 5. Missão. 6. Pastoral. I. Lima, Luis Corrêa. II. Pontifícia Universidade Católica do Rio de Janeiro. Departamento de Teologia. III. Título. 
Ao Senhor Deus que me deu graça e força para chegar até aqui: Ebenézer! 


\section{Agradecimentos}

Ao meu orientador Professor Luis Corrêa Lima pelo estímulo e parceria para a realização deste trabalho.

À CAPES/ PROSUP e à PUC-Rio, pelos auxílios concedidos, sem os quais este trabalho não poderia ter sido realizado.

Aos meus pais Euclydes (in memoriam) e Judite, pelo amor que dedicaram a mim, meu esposo Carlos Henrique e filhos Carlos Victor, Stefanie e Pedro Henrique, pela atenção e carinho de todas as horas.

Aos meus amigos Paulo César Welte e Nei Caetano por todo apoio, incentivo e parceria.

Aos professores Ana Maria Tepedino e Afonso Rubio Garcia, pelas importantes contribuições e palavras de apoio.

Aos meus colegas da PUC-Rio.

Aos professores que participaram da Comissão Examinadora.

A todos os professores e funcionários do Departamento pelos ensinamentos e pela ajuda, especialmente ao secretário Sergio Albuquerque.

A todos os amigos e familiares que de várias formas me estimularam ou me ajudaram. 


\section{Resumo}

Silvestre, Gláucia Mendes Oliveira Silvestre; Lima, Luis Corrêa. A Educação Metodista e seus Modelos Pastorais. Rio de Janeiro, 2014. 151p. Dissertação de Mestrado - Departamento de Teologia, Pontifícia Universidade Católica do Rio de Janeiro.

Refletir sobre o A Educação Metodista e seus Modelos Pastorais é um tema muito rico e amplo. Pode ser analisado e compreendido por vários olhares. Obviamente o assunto não será esgotado, mas serão destacados os aspectos mais relevantes desta discussão. Desde o início do movimento metodista na Inglaterra, no séc. XVIII, John Wesley, seu principal pioneiro, demonstrava especial atenção à educação, à vida piedosa, bem como às ações humanitárias na tentativa de alcançar e responder as necessidades do ser humano de sua época de forma integral. Sua formação acadêmica foi na conceituada Universidade de Oxford. Dedicava-se à busca do conhecimento associando-o sempre à fé cristã e à prática do amor ao próximo. O resultado da dedicação deste homem se espalhou por toda a parte através da ação missionária do Movimento Metodista onde, entre tantas coisas, fundou milhares de escolas. Nesses mais de 250 anos de educação metodista, somente nos EUA e Inglaterra foram erguidas 1.900 escolas. O ponto principal desta dissertação é a rica oportunidade de refletir sobre os rumos e a relevância da educação metodista no Brasil hoje, através de suas instituições de ensino considerando a trajetória histórica a partir de seu fundador John Wesley.

\section{Palavras-chave}

Movimento metodista; teologia da educação metodista; história do metodismo; missão; pastoral. 


\section{Abstract}

Silvestre, Gláucia Mendes Oliveira; Lima, Luis Correa (Advisor). The Methodist Education and their Pastoral Models. Rio de Janeiro, 2014. 151p. MSc. Dissertation - Departamento de Teologia, Pontifícia Universidade Católica do Rio de Janeiro.

Reflecting on the The Methodist Education and their Pastoral Models is a very rich and broad topic. It can be analyzed and understood by various looks. Obviously it will not be exhausted but the most relevant aspects of this discussion will be highlighted. Since the beginning of the Methodist movement in England in the century XVIII, John Wesley, its principal pioneer, showed special attention to education, godly life, as well as humanitarian actions in trying to reach and meet the needs of the human being of his time in full. His academic training was at the prestigious Oxford University. He dedicated to the pursuit of knowledge always associating it to the Christian faith and the practice of love of neighbor. The result of the dedication of this man has spread everywhere through the missionary work of the Methodist movement which, among many things, founded thousands of schools. In over 250 years of Methodist education, only in the U.S. and Britain were built 1,900 schools. The main point of this dissertation is the rich opportunity to reflect on the direction and relevance of Methodist education in Brazil today, through its educational institutions considering the historical trajectory from its founder John Wesley.

\section{Keywords}

Methodist movement; the methodist theological education; history of methodism; mission; pastoral. 


\section{Sumário}

1. Introdução

2. A educação metodista e seus modelos pastorais: a origem

2.1. A genealogia de John Wesley e a importância da educação

20

2.2. A formação Acadêmica de John Wesley

23

2.3. John Wesley e o papel social do movimento metodista

32

2.4. Ideias, princípios e programas educacionais de John Wesley

38

2.5. John Wesley: teologia e educação

45

2.6. O povo: o alvo da educação metodista em John Wesley

51

3. A educação metodista e seus modelos pastorais no Novo Mundo

56

3.1. O primeiro surgimento do metodismo na Geórgia

56

3.2. Legado teológico e doutrinário de Wesley para os metodistas

59

3.3. Principais doutrinas metodistas

61

3.4. Os metodistas nos EUA, a morte de John Wesley e os novos rumos do metodismo: rupturas inevitáveis

3.5. O desenvolvimento e as desigualdades sociais: o metodismo nos EUA 
4.1. Um panorama do Brasil colônia

4.2. Resistências para a chegada do protestantismo no Brasil

4.3. A Chegada dos Missionários Metodistas no Brasil

4.4 O projeto liberal republicano e o metodismo

4.5. A educação metodista no Brasil e a Conferência Anual

4.6. O ideário da educação metodista no Brasil

4.7. Escolas paroquiais

4.8. A autonomia da Igreja Metodista no Brasil e suas instituições de ensino

4.9. Diretrizes para a Educação da Educação da Igreja Metodista: uma proposta libertadora

5. Conclusão

6. Referência Bibliográfica

8. Anexo 2 - Regulamento das Pastorais Escolares e Universitária da Igreja Metodista. 


\section{Figuras}

Figura 1 - Escola Chaterhouse em Londres- Primeira escola que John Wesley estudou (1714-1720). Funcionava em regime de internato.

Figura 2 - Christ Church Oxford - local onde John Wesley estudou de 1720-1725

Figura 3 - Lincoln College, Oxford - Iniciou seus estudos nesta instituição em 1726.

Figura 4 - Imagem de John Wesley e seus amigos no "Clube Santo", na Universidade de Oxford.

Figura 5 - Rua Aldersgate, local onde John Wesley tem sua experiência religiosa denominada "A experiência do Coração Aquecido"

Figura 6 - Escola da Fundição. Primeira propriedade metodista. Uma antiga fábrica de fundição desativada que foi transformada em escola.

Figura 7 - Retrato de John Wesley pregando ao ar livre

Figura 8 - Charles Wesley pregando na Geórgia, entre os índios.

58

Figura 9 - Pintura de John Wesley em seu leito de morte

Figura 10 - Bandeira do Brasil no início da República, inspirada na bandeira americana

Figura 11 - Bandeira do Brasil atual

Figura 12 - Educação física no Colégio Bennett na década de 50

Figura 13 - Logotipo da Rede Metodista de Educação das 
Instituições de Ensino no Brasil

123

Figura 14 - John Wesley em sua velhice 


\section{1}

\section{Introdução}

A atual pesquisa contribuirá para reflexões sobre o tema "A Educação Metodista e seus Modelos Pastorais”, contará com dados históricos, teológicos, filosóficos e pedagógicos iniciando no século XVIII, na Inglaterra, perfazendo um caminho do metodismo nos Estados Unidos da América e finalmente no Brasil. A tônica será a educação metodista.

Ao redesenhar o eixo dessa pesquisa, nos deparamos com um tema que ainda pulsa tão fortemente no metodismo. Ainda há tantos desdobramentos que precisam de reflexão e realinhamento. Olhando a caminhada histórica da Educação Metodista e seus Modelos Pastorais surgem outros questionamentos, percepções e inquietações: A práticas pedagógicas das instituições metodistas no Brasil se tornaram práticas superadas? Perdeu-se o significado dos objetivos e das finalidades da educação que se é realizada? A atual educação metodista desenvolvida em suas instituições de ensino serve-se simplesmente como manutenção do sistema vigente?

Ora, se nos primórdios do metodismo na Inglaterra, a preocupação predominante de John Wesley e dos metodistas era promover uma educação para os pobres, e se, ainda, a educação metodista oriunda dos Estados Unidos da América era preparar a elite brasileira para governar, a partir dos princípios americanos de cidadania e desenvolvimento, bem como dos princípios cristãos configurados no metodismo, e considerando ainda a autonomia da Igreja Metodista na década de 30, qual o modelo que lhe tem sido definido no solo brasileiro? Há clareza dos objetivos atuais de suas escolas? Sua educação é diferenciada (como no período dos missionários norte-americanos)? Ainda há justificativa histórica para permanecer na área da educação sem ser considerada somente como mais uma escola privada no solo brasileiro? A educação metodista 
no Brasil poderia e deveria ser uma educação de serviço daqueles a quem o Senhor Jesus dirigiu o Sermão da Montanha ${ }^{l}$ Não uma educação paternalista ou reprodutora dos modelos vigentes, mas uma educação libertadora, que colabore para a libertação dos oprimidos e opressores. Uma educação capaz de desmistificar ideologias, apresentando visões de mundo utópicas a partir do Reino de Deus, resultado de uma Igreja que seja fonte de luz, comprometida com a ética do Evangelho. Uma educação que rompe a lógica da produção de consumo ou da mera reprodução de conhecimento acumulado para produzir ciência e tecnologia sem ignorar a dimensão transcendental do ser humano, a partir da fé cristã.

O metodismo universal está ligado à vida de um homem: John Wesley, que nasceu na Inglaterra em 1703 e faleceu em 1791. Viveu 88 anos. Nasceu numa Inglaterra rural e morreu num país já urbano e industrializado. No lapso de tempo da sua vida ele pôde sentir a transformação de seu país em sua evolução para a Revolução Industrial (da produção feudal para a capitalista). Passou da concepção de mundo fundamentada na visão aristotélica para o liberalismo burguês. No princípio, como pastor anglicano, Wesley olhava para dentro de si mesmo, procurando salvar-se; em seguida, preocupa-se com a reforma da Igreja da Inglaterra e a salvação dos outros.

Embora Wesley critique Rosseau e o chame de cínico, a influência de seu livro "Emílio" e seus princípios pedagógicos em sua obra educacional são claros. Também pode-se dizer que foi influenciado por pietistas com William Taylor, Thomas A. Kempis e outros.

O ano de 1738 marca o início de outra etapa da vida de Wesley. Foi neste ano seu o despertar espiritual com a denominada "Experiência do Coração Aquecido" e alteração de rumo do seu ministério.

Além de líder religioso foi também grande educador e sua obra educacional começa na cidade de Bristol, quando ele evangeliza os mineiros e marginalizados e os educa igualmente. Ele afirma que foi até Bristol para "educar as pessoas".

\footnotetext{
${ }^{1}$ O Sermão da Montanha anunciado por Jesus durante seu ministério dirigia-se especialmente aos pobres e aflitos de sua época. O texto encontra-se na Bíblia Sagrada, no Evangelho de Mateus, capítulo 5: 1-12.
} 
John Wesley, o principal fundador do Movimento Metodista assumiu como marca fundamental do seu ministério uma postura pedagógica em relação ao indivíduo e à sociedade. Ele via na educação a possibilidade de um viver com fé esclarecida, e por isso desde o início o metodismo teve por sua ênfase no binômio igreja/escola, o seu relacionamento social.

A educação faz parte da identidade metodista. Mais que uma forma de ação, ela integra a essência do Metodismo, pautado na busca constante da sabedoria e da santidade.

Pode-se dizer que a educação é uma marca indissociável do metodista. O movimento liderado por John Wesley, no século XVIII, estabeleceu as primeiras escolas metodistas na Inglaterra. Em sua concepção o conhecimento e piedade vital deveriam coexistir. Por esta razão, além de outras iniciativas educacionais, Wesley fundou escolas para crianças e adultos, junto a diversas sociedades metodistas.

Nos Estados Unidos o metodismo é um movimento educativo-religioso. A Igreja constituiu cerca de 200 estabelecimentos de ensino, dentre os quais 34 são Universidades renomadas, como: Duke, Emory, Boston University, Ohio, entre outras.

Entretanto, ao se estabelecer nos Estados Unidos da América a partir de 1784 -1785 pode-se perceber uma mudança de paradigma de sua ação teológicopastoral tomando como referência o metodismo primitivo de John Wesley, na Inglaterra. Este, imbuído numa nova realidade cultural e histórica redireciona suas perspectivas e ação: Dessacraliza o templo, assumindo a pregação em qualquer lugar disponível, acompanha a expansão territorial anunciando a liberdade que todos têm para acolher ou rejeitar a graça de Deus, cria escolas e Universidades e em pouco tempo se torna a maior e mais influente denominação do país. Crê firmemente que foi chamada por Deus para salvar as outras nações. Não somente com a pregação, mas com o modo de cidadania americana, estabelecida no progresso, no lucro, no desenvolvimento, por isso, os metodistas elaboram seus planos de expansionismos. 
Entrar no Brasil não foi simples, especialmente porque a coroa portuguesa, cria que havia sido designada por Deus para salvar os povos através de seu governo e de sua fé - o catolicismo romano. Assim durante quase três séculos após a colonização, o Brasil estava sob o domínio de Portugal, fechada principalmente às outras nações que não estivessem debaixo do seu domínio, ou que professassem sua religião.

Entretanto, o apoio político e bélico da Inglaterra para Portugal, diante de Napoleão Bonaparte fez com que acordos fossem estabelecidos entre estas nações aliadas, o que possibilitou a chegada de ingleses, mais tarde outros estrangeiros e protestantes, no Brasil.

A Igreja Católica era quem promovia a educação do país, com escolas de ensino jesuíta, com a pedagogia centrada na ration studiorium, promulgado na Contra-Reforma na Europa de 1599. Nele o ensino clássico baseava-se no conteúdo a ser visto, no método e no professor.

Paulatinamente a Constituição foi-se reformulando e abrindo espaço para a presença de estrangeiros e protestantes, ao ponto de permitir-se o culto protestante nesta nação.

No Brasil a Igreja Metodista nasceu pregando o Evangelho e ao lado de seu templo, construía-se a escola. Nelas o objetivo principal não seria "evangelizar", como no conceito usual da palavra, mas formar uma mentalidade. A preocupação do metodismo nativo é produzir uma educação que tenha o compromisso com a verdade, que reflita uma Igreja que seja fonte de luz e comprometida com a ética apostólica: uma educação libertadora; nem paternalista, nem reprodutora dos modelos vigentes.

Os metodistas com sua herança wesleyana de criar escolas como um meio não somente de instruir, mas de ensinar os fundamentos cristãos, seguiram esse mesmo conceito em terras brasileiras. Entretanto, seu foco principal era preparar as elites para governar. O modelo de educação foi uma inovação, pois trabalhavam com o método indutivo, onde a teoria e a prática eram exigências para a construção do conhecimento. 
A ética de Cristo se reflete na pedagogia onde o próximo aparece em primeiro lugar. O caráter do ser humano é à base do ensino. A criança é priorizada, pois o Reino de Deus lhe pertence por contínua herança.

Não demorou muito, após a chegada dos metodistas no Brasil, para que a discussão da "educação pública" fosse tratada e o modelo da educação metodista respondesse os anseios de um país que passava por transformações da república, com vistas ao desenvolvimento, à democracia, à cidadania e aos conceitos de ideais libertários.

Assim como a Constituição dos Estados Unidos foi utilizada como modelo para a elaboração da Constituição brasileira, o modelo da educação metodista foi utilizado como referência, a tal ponto de receber elogios das autoridades governamentais da época, tomando sua pedagogia, didática e até mobília, para serem utilizadas nas escolas públicas do país.

$\mathrm{Na}$ década de 30 a Igreja Metodista "conquista" sua autonomia da Igreja Metodista Episcopal dos Estados Unidos da América, e gradativamente os missionários e as missionárias que administravam as instituições de ensino deixaram essas direções. A maioria retorna para o seu país de origem.

Chegou o tempo da Igreja Metodista do Brasil se reelaborar. Em 1982 nasce o documento: Diretrizes para a Educação Metodista, após longa discussão. O documento define a ação de suas escolas, sua filosofia e teologia pastoral. Criam-se também as Pastorais Escolares e Universitárias que deveriam atuar representando a mantenedora e assumindo a tônica de sua confessionalidade.

Muitos desafios ainda estão na pauta deste tema. Não é suficiente a constatação da existência das instituições de ensino que a Igreja Metodista tem em solo brasileiro, mas sua finalidade, eficácia, relação com a Igreja e com a sociedade, seus anelos, as definições e redefinições teológicas de sua religiosidade, sua compatibilidade entre a vivência cotidiana e os documentos oficiais da Igreja, e ou quem sabe, a própria reelaboração teórica que hoje lhe sustenta.

Deve-se questionar, ainda: Como justificar a educação metodista com mensalidades que somente as classes médias podem aderir a ela, numa nação com 
tanta pobreza? Os missionários americanos optaram por uma educação para a elite com o propósito de formar a liderança e governantes da nação. Uma influência de cima para baixo. Este modelo deve ser perpetuado nas instituições metodistas de ensino hoje? Tem-se obtido êxito nesta finalidade? Essa é a clientela atual, predominante no Brasil em nossas escolas? As camadas populares deveriam ser priorizadas no olhar e na ação da educação metodista, assim como a formação de professores? As escolas paroquiais deveriam ser recriadas, ou o Projeto Sombra e Água Fresca deveria assumir uma ação mais operante em solo brasileiro?

O Projeto Sombra e Água Fresca é um projeto nacional da Igreja Metodista no Brasil, que visa entre outras coisas, atender as crianças no reforço escolar e atividades extracurriculares para seu pleno desenvolvimento, corroborando na sua formação, sendo oferecido no horário inverso de suas aulas na escola formal. Ele deveria ser prioridade com seu funcionamento nas Igrejas locais implementado nas comunidades metodistas de forma mais contundente? Há demanda para isso? Essas questões e outras mais deverão nos desafiar nesta leitura descobrindo respostas, possibilidades e coragem para a construção de novos caminhos.

Que as páginas que se seguem se tornem um espaço para reflexão não somente do conhecimento histórico, teológico e pastoral da educação metodista, mas uma reflexão que renove o desafio missionário da Igreja Metodista e seu papel educativo, em terras brasileiras. 


\section{2}

\section{A Educação Metodista e seus Modelos Pastorais: A Origem}

O metodismo exerceu no século XVIII grande influência na reforma social da Inglaterra. Atuante, especialmente contra o crime e a imoralidade, no exercício da caridade aos pobres e enfermos, na reforma educacional, na abolição da escravatura. Pode-se dizer que todas essas ações representam frutos diretos de sua ética. A ética que o metodismo pregava era a ética sóbria e individual da "Solene Vocação" e da piedade moraviana. Sobre o tema, Niebuhr, destaca:

"A ética do Metodismo distinguia-o das igrejas de classe média e da pequena nobreza, muito embora, nesse ponto, representasse significativo afastamento das rebeliões religiosas de pobres nos séculos precedentes (...) O movimento inspirou entre eles extensa atividade filantrópica que resultou na fundação de um grande número de instituições de caridade e na legislação humanitária nos princípios do sáculo XIX, que foram apoiadas, em grande parte, pelos discípulos de Wesley, evangélicos, membros da Igreja da Inglaterra."2

Para compreender melhor a visão educacional metodista e sua teologia pastoral, é necessário, obrigatoriamente, conhecer a formação de seu percussor, John Wesley, considerando sua origem familiar, sua infância, os princípios que nortearam sua trajetória moral, espiritual, acadêmica. Tudo isso será refletido em suas teses, ensinamentos e práticas.

Outros aspectos muito relevantes em sua formação poderão ser percebidos em sua trajetória, como: disciplina, seriedade, a solidariedade no compromisso com os excluídos da sociedade. Essas marcas acompanharão todo o empreendimento educacional de Wesley e sua dedicação à evangelização.

\footnotetext{
${ }^{2}$ Richard A. Niebuhr. As Origens Sociais das Denominações Cristãs, 1992, p. 47
} 


\section{1}

\section{A Genealogia de John Wesley e a Educação}

O mundo ancestral próximo de John Wesley: bisavô, avô, pai, mãe, constitui uma tradição de estudiosos e pessoas altamente preparadas, compondo uma absoluta minoria das pessoas letradas dos séculos XVII e XVIII. Neste período o que era importante para a sociedade, eram os títulos da nobreza, as propriedades e o dinheiro. A educação e a cultura eram secundárias.

Com exceção de seu pai Samuel e sua mãe Suzana, os demais ancestrais pertenciam ao grupo dos Dissidentes, que se negaram a assinar o Ato de Uniformidade, em 1662, que os obrigava a serem subservientes ao Estado e ao Rei.

a) Bartolomeu Wesley- bisavô paterno, pregador leigo da Igreja Dissidente. Estudou Teologia e Medicina na Universidade de Oxford. Com a restauração da Monarquia, e a decretação do Ato de Conformidade, em 1662, foi expulso de sua paróquia por negar-se a assinar o documento.

b) John Wesley - avô paterno, também estudou Teologia em Oxford, alcançando o título de Mestre, em Artes. Como Dissidente, foi preso em 1661(devido a Lei das Cinco Milhas) ${ }^{3}$ pregando o Evangelho foi outras vezes levado ao cárcere. As privações e sofrimentos o levaram à morte muito cedo, aos 42 anos de idade.

c) Samuel Wesley - Pai de John Wesley nasceu em 1662, sendo educado em um lar Dissidente ${ }^{4}$, Não-conformista. Frequentou uma escola dissidente (Dorchester Grammar School), quando se desiludiu com os Dissidentes, transferindo-se para a Igreja Oficial. Cursou a faculdade em Oxford, como aluno pobre, onde se formou em 1687 e tornou-se pastor da Igreja Anglicana. Publicou diversos livros, onde ficam evidenciadas suas inclinações acadêmicas. Era membro da Sociedade Literária de Londres. A

\footnotetext{
${ }^{3}$ Henry Carter. The Methodist Heritage, 1951, p. 53 et. seq. (As "Cinco Milhas" era dirigida contra os pregadores Dissidentes, não-conformistas, proibindo de se aproximarem de vila ou cidade, onde tivessem exercido o pastorado).

${ }^{4}$ Mateo Lelièvre. Juan Wesley: Su vida y su obra, 1911, p. 28.
} 
partir de 1696, foi o pároco em Epwort, onde permaneceu até a sua morte, em 1735. De acordo com Mateo Lelièvre, Samuel Wesley era,

“... de inteligência mais universal que profunda, produzia uma grande variedade de publicações literárias, como folhetos políticos e religiosos, artigos para os periódicos, poemas, comentários e trabalhos de teologia $(. . .)^{5}$

Bartolomeu, John e Samuel, ancestrais paternos de Wesley, constituíram famílias nas quais o amor aos estudos, à educação e à cultura foi notável exceção, num mundo de analfabeto. Raríssimas eram as escolas, basicamente restrita à nobreza e pouquíssimos alunos pobres.

d) Dr. Samuel Annesley (avô materno) - Pai de Suzana Wesley e primo de Arthur, primeiro conde de Anglesea era de igual modo homem de refinada educação. Segundo Mateo Lelièvre, Samuel Annesley era:

“Homem de caráter e educação (...), foi educado no Queen's College, na Universidade de Oxford, (...) foi ordenado capelão no navio Globe de sua Majestade (...) mais tarde foi pastor em Cliff, no condado de Kent. (...) Mais tarde foi expulso de sua paróquia, por ser um Não-conformista”.

e) Suzana Wesley (mãe de Wesley) - reconhecida por muitos estudiosos não simplesmente como a mãe de John Wesley, mas a "Mãe do Metodismo". 6 Ela foi uma mulher que levou a sério seu preparo intelectual, desde cedo.

"(Suzana) possuía natural inclinação para o estudo. Ela sábio o grego, latim e francês, antes de ter seus 20 anos de idade, e achava-se saturada de teologia. (...) Ela lia os padres primitivos e lutava com as sutilezas da metafísica. (...) Com treze anos apenas, ela recusou toda a matéria em discussão entre os Dissidentes e a Igreja Anglicana, opinando contra a posição mantida por seu pai". ${ }^{7}$

Suzana governou sua família e seu lar com extraordinária força, disciplina e amor. Foi cuidadosa ao disciplinar seus filhos, desde o início de suas vidas, exigindo que eles gastassem parte de seu tempo a cada dia, com ela, para o propósito de sua educação. Lunn afirma:

"Mulheres como Suzana Wesley exerceram poderosa influência nos destinos das gerações, influência ainda maior, porque não dependia de direitos legais ou privilégios politicos". 8

\footnotetext{
${ }^{5}$ Arnold Lunn. João Wesley, 1929, p. 28.

${ }^{6}$ Mateo Lelièvre, op.cit. p. 34.

${ }^{7}$ W. H. Fitchett. Wesley e seu Século, 1916, p. 16 et. seq.

${ }^{8}$ Arnold Lunn, João Wesley, 1929, p. 12.
} 
Suzana Annesley Wesley teve 19 filhos, dos quais somente nove sobreviveram. Ela buscou desenvolver a mais rica e completa educação para seus filhos e filhas, através de uma pedagogia e prática, contendo: disciplina, o castigo, o perdão, o horário, o silêncio, a vontade, a oração, o efetivo aprendizado, o cumprimento estrito das promessas, a paciência, a persuasão e o amor. Esses valores deveriam ser dosados com sabedoria.

Desde bem pequeninos as crianças eram ensinadas a chorar suavemente, logo que pudessem falar, aprendiam a Oração do Pai Nosso. No dia se seus aniversários, quando completavam cinco anos de idade, aprendiam na Bíblia as letras do alfabeto de cor, as letras maiúsculas e minúsculas. Depois entravam para a escola que funcionava no próprio lar, sob a direção metódica de Suzana. As crianças maiores ajudavam as menores. A escola funcionava diariamente, de $9 \mathrm{~h}$ às $12 \mathrm{~h}$ e de $14 \mathrm{~h}$ às $17 \mathrm{~h}$. O uso organizado do tempo e a distribuição de suas responsabilidades diárias Wesley aprendeu com sua mãe, o que lhe foi muito útil em Oxford e mais tarde no clube santo.

Atualmente, alguns princípios pedagógicos e mesmo éticos podem ser questionados por atuais educadores e psicopedagogos, porém o fundamental é que Suzana tinha plena consciência da importância de se ter uma metodologia educacional e que deveria aplicá-la de forma consistente. Oliveira destaca que:

"Os possíveis defeitos pedagógicos foram supridos pela sua extraordinária capacidade de amar seus filhos". 9

Nesse pequeno panorama do contexto intelectual, cultural e educacional, percebe-se o seio familiar onde John Wesley cresceu. Os ancestrais de Wesley, tanto do lado paterno quanto materno valorizavam profundamente o seu amplo preparo no mundo da educação. Todos, incluindo Suzana, foram pessoas cultas, de notável saber. Por outro lado, foram pessoas muito pobres, que lutaram arduamente para garantir a sobrevivência. Essa riqueza influenciou, absolutamente, a formação de John Wesley e de seus irmãos. Todos os meninos de sua família se formaram na Universidade de Oxford.

\footnotetext{
${ }^{9}$ Clori Trindade de Oliveira, Revista COGEIME, Ano 12, Número 22, 2003.
} 
Seu irmão mais velho, Samuel, tornou-se diretor da Blundell's School, em Devon. Sua irmã Emily, tornou-se professora de uma escola em Lincoln e mais tarde abriu sua própria instituição de ensino. Sua outra irmã, Hetty, publicou poesias no Poetical Register e a The Gentleman's Magazine, uma das principais revistas literárias de Londres.

\section{2}

\section{A Formação Educacional de John Wesley}

John Wesley nasceu em Epworth, no condato de Lincolnshire, no dia 17 de junho de 1703. Era o $12^{\circ}$ dos 19 filhos de Suzana e do reverendo Samuel Wesley, um pároco de Epworth. Seu pai era clérigo da Igreja Anglicana, numa vila pantanosa, no meio da Inglaterra.

Suzana, sua mãe, mulher determinada e organizada assumira o método de alfabetizar cada um de seus filhos. Por isso, no dia que completavam cinco anos de idade ela sentava-se com a criança e ensinava-lhe o alfabeto maiúsculo e minúsculo utilizando como cartilha, a Bíblia Sagrada. Depois de alfabetizada a criança deveria participar regularmente da escola que criara em sua própria casa, onde os irmãos mais velhos ajudariam os irmãos menores. A escola funcionava no horário da manhã e da tarde.

Entretanto, outro episódio foi determinante na vida de John Wesley quando o mesmo ainda estava com cinco anos de idade: ele quase perdeu a vida num incêndio, provocado por um grupo de malfeitores. $O$ fogo se alastrava na casa paroquial, onde eles moravam, começando a estilhaçar brasas sobre as camas. Subitamente, Hetty Wesley, um dos irmãos menores, acordou assustado e correu até o quarto de sua mãe. Logo todo mundo estava em pé, tentando conter o domínio das chamas, enquanto a pequena criada, agarrando o bebê Charles nos braços, chamava as crianças para um lugar mais seguro. 
A família finalmente conseguiu sair de casa e, apavorada, reuniu-se no jardim, quando descobrira que o pequeno Jeckie (John Wesley) havia ficado lá dentro dormindo. Voltaram correndo, mas era tarde: a escada estava em cinzas e tornava impossível resgatá-lo. O menino chegou até a janela, porém não podiam segurá-lo, visto que o quarto ficava no segundo andar da casa. Todavia, os vizinhos vendo a aflição da família resolveram buscar uma forma de resgatar o pequeno John Wesley e conseguiram: os homens foram subindo nos ombros uns dos outros, formando uma escada humana, até que finalmente alcançaram o menino na janela, salvando a criança.

Sua mãe, Suzana, ao ver o desfecho de resgate, agarrou seu filho e ali pôde ter a certeza que se Deus o livrara do fogo da morte daquela forma, seria por ter um propósito muito especial com a vida daquele menino. Prometeu a Deus e a si própria cuidar dele com zelo, para que os propósitos de Deus fossem cumpridos na sua vida. E assim o fez.

John Wesley é reconhecido como um dos homens de mais vasta cultura do século XVIII, a Inglaterra. Cultura eclética que variou desde os clássicos até os que eram elaborados em seus dias como ensaios, novelas, peças teatrais, tratados, história política, ciência.

Seu amor pela educação nasceu num lar onde havia compromisso com as realizações intelectuais e a prática religiosa. Sua mãe, Suzana destaca-se pela disciplina na criação de seus filhos, reservando tempo diário para consolidar a formação de cada um deles. De sua mãe herdou valores como: trabalho duro, a simplicidade e o estudo disciplinado. Esses valores iriam permear toda a sua vida. Certa vez escreveu em seu diário: "Não me lembro de nunca ter retido qualquer dúvida da minha mãe - ela era o coração, aquela a quem eu depositei confiança absoluta, desde a minha infância até o dia de sua morte”.

Desde muito cedo Wesley demonstrou sua necessidade de encontrar explicações suficientes para os fatos, revelando seu espírito lógico e ávido. Seu pai, percebendo essa característica do filho, certa vez comentou com sua esposa 
Suzana: "Acho, querida, que Joãozinho não comeria seu jantar se não achasse uma razão para fazê-lo". ${ }^{10}$

Em janeiro de 1714 foi admitido no Colégio internato em Chaterhouse como estudante bolsista (recebeu a bolsa de estudo do Conde de Buckinghan) onde obteve sua formação clássica e se preparou para a faculdade. Em 1720 (com 17 anos de idade) foi admitido na Universidade de Oxford, estudante da Christ Church, bacharelando-se em 1724. Um ano mais tarde é eleito "professor monitor" no Lincoln College e ordenado diácono.

Em 27 de março de 1726, foi eleito para uma vaga de fellowship. ${ }^{11}$ (professor titular de grego) no Lincoln College, em Oxford. Em resposta a esta notícia seu pai Samuel Wesley o escreve: "onde quer que esteja, meu Jack é Fellow do Lincoln". Com esse cargo, John Wesley teve a garantia de um sustento básico e casa, comida e estudantes sob sua responsabilidade (juntamente com um salário anual até o fim de sua vida, desde que permanecesse solteiro). Em 1727 recebe o grau de mestre em Artes.

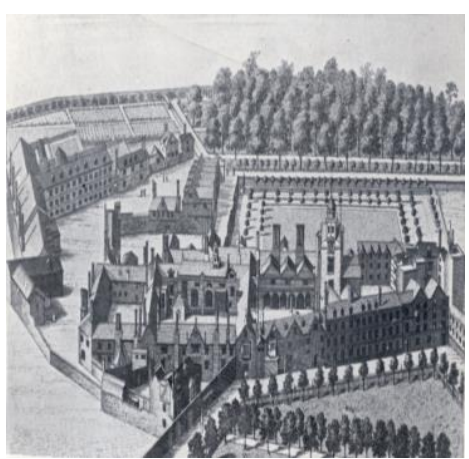

FIG 1 - Chaterhouse College

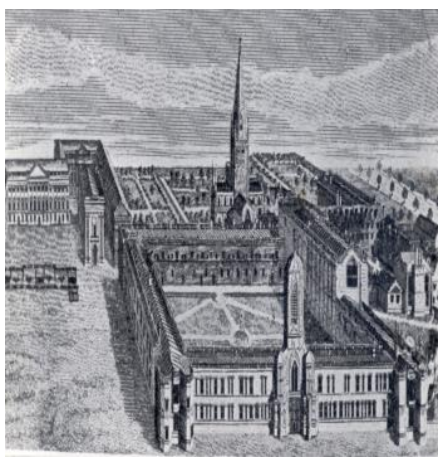

FIG 2 - Christ Church, Oxford

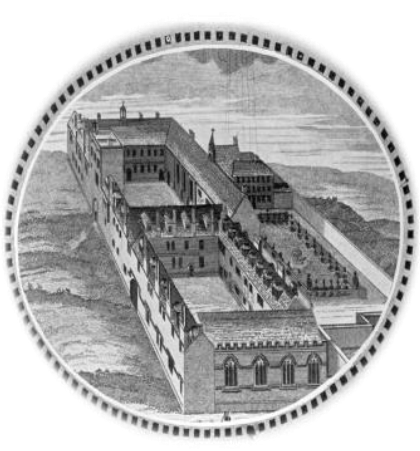

FIG 3 - Lincoln College, Oxford

Oxford possuía um extraordinário acervo de livros de ciência. É nesse período que Wesley desenvolve e aprofunda sua formação cultural. Nesses anos ele estuda grego, latim, hebraico, árabe, lógica, filosofia, medicina metafísica, Bíblia, teologia, ética, oratória, música, poesia e etc. Dedicou-se aos estudos da

\footnotetext{
${ }^{10}$ W. H. Fitchelt. Wesley e seu Século, Volume I, 1927, p. 50.

11 "Fellowship" era uma das categorias de professores na Universidade de Oxford.
} 
Bíblia em seus dialetos originais e nas pesquisas, particularmente nos Clássicos da Patrística e período Medieval.

Em carta para sua mãe Suzana, escreve informando-a de seu plano metódico de estudos, que cumpria no uso programado do seu tempo, se dedicando aos estudos e à religião.

“(..) segundas e terças aos estudos gregos e latinos; quartas-feiras aos estudos de lógica e da moral; quintas-feiras, aos estudos da língua hebraica e árabe; sextas-feiras aos estudos de metafísica e filosofia natural; aos sábados, retórica e poesias; aos domingos estudos da teologia (...)". ${ }^{12}$

Além disso, ainda reservava tempo para estudos diversos, vida de oração, visitas, leitura de livros devocionais, prática de exercícios físicos diários. É bom lembrar que Wesley levantava diariamente às quatro horas e deitava-se às onze horas da noite.

Também se juntou a um grupo de acadêmicos com o mesmo tipo de pensamento, voltado para uma vida de mais devoção religiosa e dedicação aos estudos. O grupo foi apelidado de "Clube Santo", mais tarde sendo conhecidos como os "metodistas". A criação do "Clube Santo", por Charles Wesley implicava em um estilo de vida disciplinada até os mínimos detalhes. O metodismo não surgiu como um cisma da Igreja da Inglaterra. Seu fundador, inclusive, nunca teve a intenção de criar uma nova Igreja. Adiante será visto que o surgimento da Igreja Metodista mais como um "acidente histórico", fruto do nacionalismo norteamericano por ocasião da Guerra Civil, do que pela intenção do seu fundador. Logo, podemos afirmar que o metodismo nasceu no espaço da Universidade, quando Wesley reuniu os discentes para estudar e orar, porém seu caráter é informal, espontâneo e popular. Ele aproveitava a ocasião para compartilhar seus conhecimentos da educação secular e bíblica. ${ }^{13}$ Durante os anos seguintes foi tutor de seus alunos e leu diversas literaturas.

\footnotetext{
${ }^{12}$ Obras, v. XII - Cartas a Suzana, p. 9.

${ }^{13}$ Frederich E. Maser, The story of John Wesley's Sisters, 1988, p. 22 et. seq.
} 


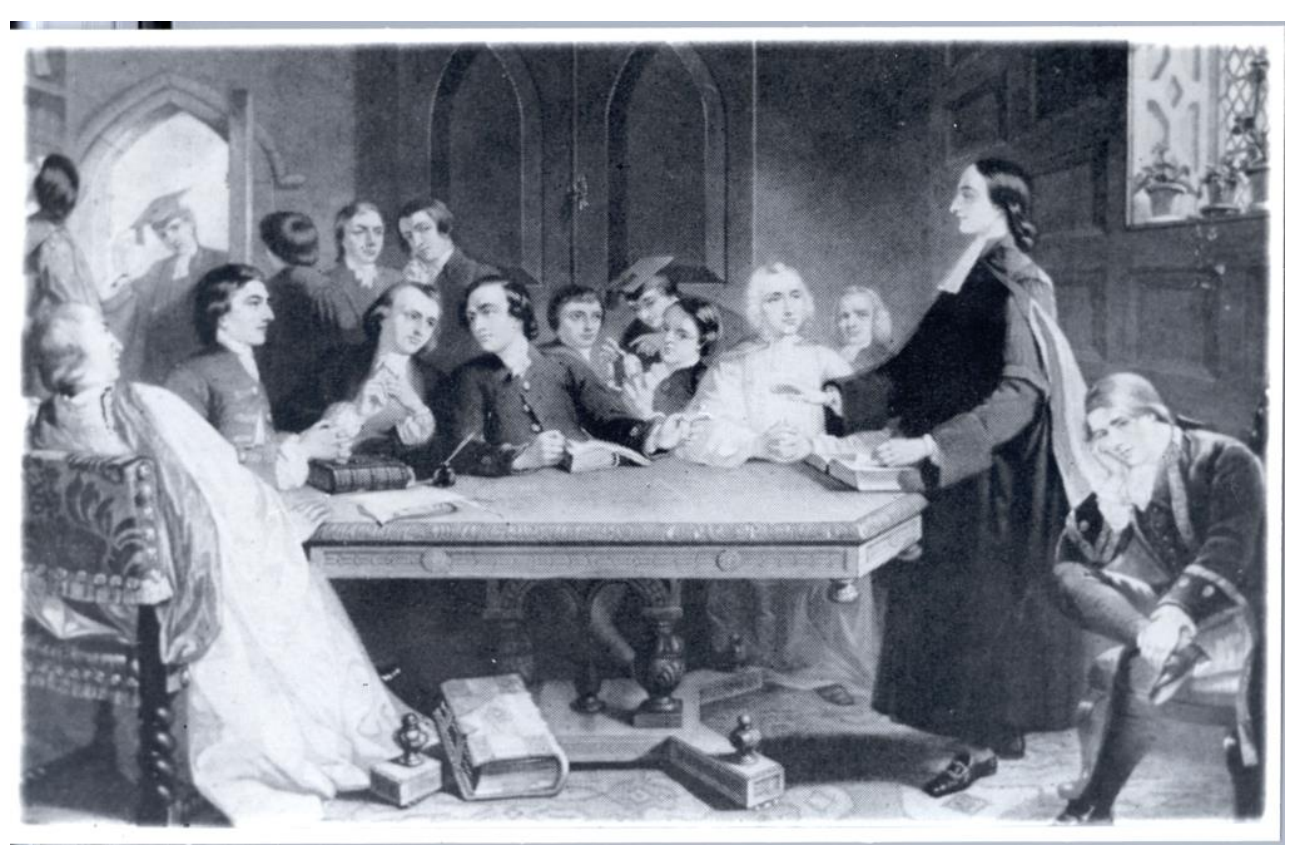

FIGURA 4 - John Wesley em uma reunião do Clube Santo em Oxford

Wesley imprimiu, na sua mensagem e no seu ensino o significado de liberdade de consciência, como um valor a ser cultivado. Ele mesmo se submetia à correção por qualquer erro que pudesse cometer:

"Mas, alguns podem dizer que tenha eu próprio errado o caminho, embora tomando o encargo de o ensinar aos outros. (....) Asseguro, porém, que onde quer que eu tenha errado, minha mente está aberta para a convicção em contrário. Desejo sinceramente ser melhor ensinado. Digo a Deus e aos homens: aquilo que eu não sei, tu mo ensinas." 14

John Wesley sempre foi um homem prático. Entendia o valor de qualquer coisa ou verdade, na medida em que isso produzisse algum resultado significativo, sua razão de ser e sua função. Do mesmo modo aplicava essa visão ao ensino de algum princípio que deveria redundar em algum resultado (fruto). Assim, o "Clube Santo" era organizado com um programa de exame diário das ações durante o dia e dos planos para o dia seguinte. Ele distribuía tarefas para pequenos grupos: alguns conversariam com os jovens da Universidade, visando ajudá-los; outros instruiriam e ajudariam as famílias pobres; outros fariam um trabalho na escola especial para crianças; outros ainda iriam ao presídio da cidade e na capela que havia lá (liam livros para os prisioneiros que compravam com seus próprios

\footnotetext{
${ }^{14}$ John Wesley. Sermões, Volume I (Prefácio), p. 24.
} 
recursos e com a ajuda das contribuições de outros que cooperavam com um fundo para este fim, remédios e outras coisas mais para suprir-lhes as necessidades básicas). Esse espírito intensamente prático de Wesley será expressamente vivido no movimento metodista.

Wesley soube aproveitar as oportunidades que se abriram para os estudos e o mundo intelectual da ciência e da religião. Durante os 10 anos que passou em Oxford, seus diários registram a leitura de mais de 900 livros. Ele foi um estudante no sentido pleno da palavra, durante toda a sua vida. Suas ênfases sempre foram: a religião e o estudo disciplinado, como caminho prático para a vida. Seu fundamento da educação seja secular ou bíblica, está na convicção teológica de que o ser humano nasceu para crescer sempre. Ele afirmou:

"Não há perfeição em grau, como se diz; nenhuma há que não admita crescimento. Quanto mais alto tenha subido o homem, por mais elevado que seja o grau da sua perfeição, ele ainda tem necessidade de crescer em graça e avançar diariamente no conhecimento e no amor de Deus". ${ }^{15}$

A partir de 1725, Wesley registrou praticamente a totalidade de suas leituras, abrangendo mais de 1.400 diferentes autores e mais de 3.000 documentos, segundo as pesquisas do teólogo e historiador, Albert C. Outler. Wesley cita, entre outros: Horácio, Virgílio, Ovídeo, Cícero, Ju venal, Aristófanes, Adriano, Homero, Lucasso, Lucrécio, Persides, Píndero, Sêneca, Agostinho, Kempis, cita autores e a Patrística, os Místicos Medievais, escritores seculares da Renascença e autores da ciência Moderna.

"Seu gosto passou pela totalidade do mundo da literatura, desde os clássicos, até o que era em seus dias, os mais novos ensaios, novelas, peças teatrais, tratados (...) interessado também, com a história, a política e presentes mudanças sociais (...) e últimas descobertas cientificas (...), 16 .

Esses dados demonstram Wesley como um incansável leitor. Isso revela o amor de Wesley aos estudos, à formação cultural na sua diversidade e complexidade.

\footnotetext{
${ }^{15}$ Sermões, Volume III, p. 284.

${ }^{16}$ Albert C. Outler. John Wesley, 1964, p.3-4.
} 
Em 1731 tornou-se responsável pelos debates públicos no Lincoln College, de onde vem não somente sua prática na lógica formal, mas na retórica e argumentativa. Ao mesmo tempo em que exercia essas funções, manteve vários postos como pregador em capelas diferentes na Universidade de Oxford ${ }^{17}$.

Em 1732 escreve à sua mãe, pedindo-lhe que lhe dissesse de modo sistemático quais havia utilizado para a educação de sua família, para que pudesse aplicá-las em sua tarefa de ensinar nas escolas para crianças carentes, pelo que sua mãe lhe escreve em 24 de julho de 1732:

"De acordo com seu desejo juntei as regras principais que observei na educação da minha família; as quais lhe mando como se me apresentaram à mente, e se você (se julgá-las de proveito) pode dispor delas como quiser.

(...) A fim de formar a mente das crianças, a primeira coisa a fazer é vencerlhes a vontade e trazê-las ao ponto de obedecer. Formar o entendimento é obra que exige tempo, e deve, como criança, ir devagar, segundo possam aceitá-lo. (...) Eu insisto no vencimento da vontade da criança, cedo, porque este é o único, forte e racional fundamento da educação religiosa, sem o qual tanto o preceito quanto o exemplo ficam sem efeito. Mas quando isso é bem feito, então a criança é capaz de ser governada pela razão e piedade dos pais, até seu entendimento amadurecer, e os princípios da religião criar raízes em sua mente. (...) a religião não é nada mais que fazer a vontade de Deus, e não a nossa própria vontade; que o único e grande impedimento à nossa felicidade temporal e eterna é a obstinação, qualquer indulgência dela não pode ser cousa trivial. O céu e o inferno dependem somente disso. (...)

Em nosso lar, logo que podiam falar era ensinado o "Pai Nosso" que era repetido na hora de levantar e deitar, ao qual quando maiores se acrescentavam outras orações, o catecismo e algumas porções das Escrituras, de acordo com sua capacidade. (...)

Muito cedo na vida meus filhos aprenderam a distinguir o domingo de outros dias da semana, (...) aprenderam a ficar quietos na hora do culto doméstico, (...) que não seriam atendidas se gritassem por alguma coisa.

A nenhum ensinava a ler e escrever antes dos cincos anos de idade (...) $O$ método de ensiná-los era o seguinte: (...) um dia designado para aprender as letras maiúsculas e minúsculas.

Logo que sabiam as letras, começaram a soletrar, e depois a ler uma, duas e mais linhas, e depois um versículo; antes de sair para o recreio lia tudo que tinha estudado no periodo da manhã, e assim no fim do dia, tinha lido tudo o que estudara durante o dia. (...) Cada qual se dedicava ao seu estudo, por seis horas de aulas. (...) Adotamos o hábito de cantar salmos na abertura das aulas, de manhã e à tarde.

(...) Quem quer que tenha sido acusado de ter comentido falta do qual era de fato culpado, se a confessasse sinceramente, e prometer-se corrigir-se, não seria castigado; nenhum ato pecaminoso seria permitido passar sem ser

\footnotetext{
${ }^{17}$ Heitzenrater, John Wesley and Oxford Methodists, 1972, p. 332 et. seq.
} 
castigado; cada sinal de obediência devia ser reconhecido e recompensado; a propriedade deverá ser conservada, e a ninguém era permitido invadir a propriedade do outro; que promessas sejam rigorosamente guardadas; que nenhuma menina seria ensinada a trabalhar antes de saber ler bem. Esta regra deve ser observada, porque o fato de meninas serem obrigadas a trabalhar (coser, por exemplo) antes de aprender a ler bem é a razão por que tão poucas mulheres sabem ler com aceitação e não são entendidas. ${ }^{18}$

Em 1735 Wesley deixou Oxford para tornar-se um missionário na recém colonizada, Geórgia. Em 1736 organiza uma escola para meninos e meninas e escreve um "Catecismo para Crianças".

Três anos mais tarde desde sua chegada aos Estados Unidos, retorna à Inglaterra e em 24 de maio de 1738 tem uma profunda experiência religiosa que mudou sua vida. Foi quando Wesley participou de uma reunião de oração na Rua Aldesgate. Enquanto ouvia a leitura do prefácio de Lutero da carta aos romanos, sentiu seu coração estranhamente aquecido e sentiu o perdão de Deus sobre seus pecados. Nos anos seguintes ele realizaria coisas que nunca teria imaginado realizar.

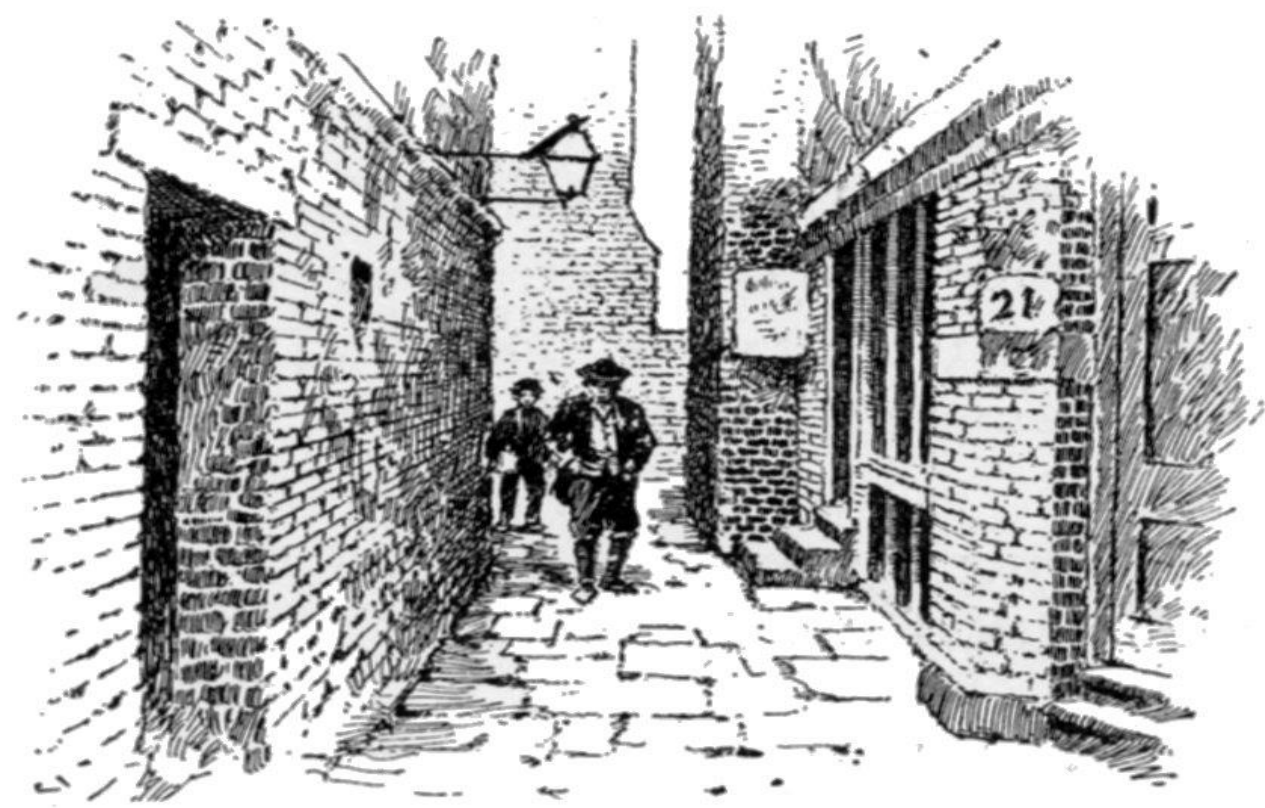

FIGURA 5 - Desenho da Rua Aldersgate

\footnotetext{
${ }^{18}$ Diário de John Wesley - Domingo, 1 de agosto de 1742. Após a morte de sua mãe, Wesley relembra algumas cartas que ela escrevera. Entre elas esta, datada de 24 de julho de 1732 .
} 
Seu compromisso com a educação pode ser comprovado ao longo de sua vida ministerial, desde a criação da primeira escola metodista em Kingswood, à criação da biblioteca cristã.

Naquela época, só existiam três grandes escolas reconhecidas na Inglaterra: Winchester, Westminster e Eton. Havia também, alguns colégios de caridade. Wesley queria um colégio de qualidade somado aos valores cristãos.

O Colégio em Kingswood foi iniciado em 1748, com uma doação de 800 libras, feita pela Condessa de Huntingdon, numa longa tradição de filantropia. Wesley demonstrou de forma concreta o compromisso do metodismo com a educação que tem perdurando por mais de 250 anos.

Em 1784 surge a primeira instituição de ensino metodista das Américas, em Abington, Maryland - Cokesbury College. Desde então mais de 1200 instituições de educação foram criadas, dentre as quais 123 permanecem até os dias atuais.

Sem dúvida alguma, a educação é um pilar central na visão de Wesley de um mundo novo. Seus destaques principais eram para as crianças e pelos pobres. Desde o tempo do "Clube Santo", em Oxford, dedicou-se para organizar e construir escolas para os pobres.

Em 1739 ele prepara um manual de instrução para as crianças e pede que os pregadores metodistas expliquem a elas, em suas visitas aos lares. A partir de 1748, solicita aos pregadores metodistas que nas sociedades onde houvesse pelo menos dez crianças, se tivesse classe semanal com elas. Em 1756, em Dublin, na Irlanda, John Wesley se reunia duas vezes por semana com o grupo de mais de cem crianças para a educação cristã.

Pode-se perceber que ao longo da vida de Wesley, a educação sempre foi uma de suas mais legítimas preocupações e empenho. Educação, esta, como fundamento da nova vida e na construção de um mundo novo. Por onde Wesley e o Metodismo passassem, a educação seria profundamente valorizada, na organização de pequenas e grandes escolas, para crianças pobres, filhos e filhas dos pregadores metodistas, para os pais analfabetos, etc. Segundo Clory Trindade de Oliveira, 
"A educação, sem dúvida alguma, é marca distintiva e indissolúvel do movimento metodista. A capela e a escola, no Metodismo, sempre andaram juntas". 19

\section{3}

\section{John Wesley e o Papel Social do Movimento Metodista}

Na vida de John Wesley constata-se o derramar do amor divino em seu coração e a dádiva de seu amor pelo seu semelhante. Por amar ardentemente o ser humano, Wesley desejava levar-lhe com todas as suas forças e coração o amor redentor de Cristo. Amou a todos intensamente e sinceramente, sem discriminação, numa época cheia de preconceitos, separações, menosprezos e marginalizações. Em especial amou os abandonados, desprezados, pobres e desesperados, valorizando suas vidas e trazendo-lhes a esperança e o poder do evangelho de Cristo. ${ }^{20}$

É bom lembrar que quando o movimento surgia na Inglaterra, o conceito de sujeito passava por profundas transformações. Antes disso compreendia-se que a pessoa era vinculada com a experiência de união com Deus O Iluminismo afirmava que a pessoa é um sujeito centrado em si, "unificado, capaz de usar sua razão, sua consciência e ação (...)". ${ }^{21}$ Já a natureza é compreendida como uma grande máquina. Essa ideia de máquina está relacionada com "mecanismo", causalidade e necessidade de manipulação. Nessa mentalidade, Deus, como maquinista ou criador técnico, permanece por certo tempo (Deísmo), mas desaparece aos poucos. Assim, Deus não está mais disponível para formar identidades, culturas, sistemas sociais, comportamentos, enfim, o sujeito. ${ }^{22}$

\footnotetext{
${ }^{19}$ Clory Trindade de Oliveira. Revista COGEIME, Ano 12, no. 22, p. 75, 2003.

20 Texto escrito pelo Bispo Nelson Campos Leite, na apresentação do livro João Wesley o evangelista, Coleção Metodismo, 1992, p. 9.

${ }^{21}$ Texto do Dr. Helmut Renders - Papel Social e Subjetivação do Metodismo Nascente. Revista CAMINHANDO - Ano IX, 2004, da Faculdade de Teologia da Igreja Metodista, UMESP, SP.

${ }^{22}$ Um símbolo desta transição é o uso da ideia de Adam Smith da "mão invisível" que rege a economia. Para uns é um sinal da providência divina com a consequente sacralização da ordem econômica. Para outros é a primeira noção da lei da auto-organização de sistemas complexos.
} 
O significado de "indivíduo" e o conceito de "social” no século XVIII é anterior aos desenvolvidos pela Sociologia e pela Economia Política. Entretanto, como Wesley era um leitor veraz concebia uma boa noção sobre os temas. Conhecia Hobbes, Locke, Rousseau, e possuía razoável informação dos estudos econômicos da Inglaterra (como por exemplo, dos fisiocratas ingleses).

O "social” em Wesley é teológico - espelha uma hermenêutica bíblica do indivíduo socializado e do povo que se consubstancia em pessoas. Com esta visão, a teologia wesleyana resistiu ao dualismo indivíduo-sociedade das tendências individualistas modernas. Só existe pessoa onde o social lhe é essencial e sem o qual ele não pode ser. Estar voltado para o social não é uma atitude de "acréscimo" da fé. Ela é, para o líder do movimento metodista, uma parte espontânea, natural, por ser-lhe da essência. O imenso volume da ação educativa, de preocupação com a saúde popular, ou com a condição geral do povo emana da práxis da fé, como algo de sua natureza mais própria.

John Wesley teve essa ênfase social mais acentuada a partir de sua experiência religiosa. Essa experiência religiosa se deu pelo clássico caminho da experiência mística. Suas incertezas e incapacidades de fazer a vontade de Deus lhe resultaram numa crise, a tal ponto que até pensara em abandonar o ministério e as pregações. Porém, um amigo moraviano, Pedro Böller, lhe dá um conselho que lhe surge como nova esperança: "Wesley, não deixe de pregar sobre a fé até que a alcance, e depois de alcançá-la, continue pregando sobre ela”. Ainda, com outro amigo, mais um conselho the reanima: "O indivíduo precisa não somente de Deus, mas de outro ser humano para chegar até Deus." ${ }^{, 3}$ A comunhão humana não substitui a busca de Deus, mas pode ajudar na sua procura.

Mesmo quando Wesley relatou em seu diário que em 1738, no dia 24 de maio, ele foi à uma reunião de oração na Rua Aldersgate onde um leigo começou a ler o prefácio que Lutero havia escrito sobre a Epístola do Apóstolo Paulo aos romanos. Nesse instante, descreve que sentiu seu coração estranhamente aquecido que de seus pecados estava perdoado: uma experiência com a graça incondicional de Deus, como citada anteriormente. Essa experiência aconteceu em grupo:

\footnotetext{
${ }^{23}$ Thomas COKE e Henry MOORE. The life of the Rev. John Wesley. 1792, p. 55.
} 
humano e divino se encontram. Essa experiência estruturará, em seguida, as sociedades metodistas. ${ }^{24}$

Wesley afirmou: "Não há religião cristã se não for social, não há santidade se não for santidade social".

Assim sua experiência pessoal com a graça de Deus não o enclausurou dentro de uma religião, ao contrário, na mesma proporção o aproximou do seu próximo, especialmente os pobres e necessitados. Wesley dizia que conhecia os pobres mais que qualquer outro cidadão inglês de seu país, da sua época. Nesse encontro contínuo com os pobres Wesley desenvolveu uma sensibilidade solidária que se tornou uma marca dos metodistas. Para proteger esses desprotegidos, Wesley organizou em cada uma das sociedades metodistas uma rede de apoio que procurava reformar as instituições que não contemplavam o pobre de forma devida. Ainda organizava os pregadores e líderes metodistas de tal modo, que semanalmente visitassem os pobres.

Segundo Wesley, essa organização social tinha a vocação de servir a Deus e a obrigação de servir os pobres. Corroborando para este fim, criou uma organização financeira e patrimonial. Essa tônica pode ser observada inclusive nas Regras de Ecônomos:

"Se você não consegue redimir os pobres, então não cause amarguras aos pobres. Se não houver nada a oferecer, fale palavras carinhosas. Cuide-se para não olhá-los com arrogância, nem fale palavras grosseiras. Eles devem ficar felizes quando vierem a vocês, mesmo que voltem de mãos vazias. Coloque-se mesmo no lugar dos pobres, e trate-os como Deus os trataria." 25

O sistema administrativo metodista deveria representar a graça, a justiça, a misericórdia e a paz, numa economia eclesiástico-social.

No fim de sua vida, Wesley concluiu: "A maioria das pessoas com riquezas na Inglaterra amam o dinheiro, até os chamados metodistas". Questionou a disponibilidade de ricos para uma vida a favor do Reino de Deus.

\footnotetext{
24 MATOS, Wesley e os encontros com grupos pequenos, in Revista Caminhando, ano VIII, número 12, 2-2003; in, RENDERS, Pequenos grupos na tradição metodista: observações, análises e teses. Revista Caminhando, Ano VII, número 10, 2-2003, p. 68-95.

${ }^{25}$ Diário de John Wesley, 04/06/1747, regra 11.
} 
$\mathrm{Na}$ análise de Wesley as pessoas de posse mudariam suas posturas somente pela convivência com os pobres. "Temos a tendência de criticar nos poderosos uma falta de compaixão, mas o que realmente falta é que eles simplesmente percebam os pobres". Wesley novamente está propondo uma experiência de encontro e aproximação.

John Wesley enfatizou o tema "Negar-se a si mesmo", no Sermão 48. Esse sermão introduz cinco sermões sobre temas éticos, inclusive o famoso sermão 50, "O uso do dinheiro", com sua máxima: "Ganhai o máximo que puderes, economizai o máximo que puderes e doai aos pobres o máximo que puderes".

Isso em Wesley não significava uma ação de caridade para ser abençoado, ou da busca da salvação pelas obras, ou de compreender a abnegação como alago destrutivo, como os iluministas. Ele ainda afirma: "Não se trata de matar a carne, mas de buscar a vontade de Deus e segui-la."

Nas Regras Gerais dos Metodistas, dizia: "Não praticar o mal, zelosamente praticar o bem; atender as ordenanças de Deus”. O cumprimento dessas regras era o único modo de permanecer nas sociedades metodistas.

Já numa visão mais alargada sobre o bem social, Wesley afirmava: "Reformar a nação, especialmente a Igreja, e espalhar a santidade bíblica por toda a terra". Ele via as reformas como resultado de lutas que precisavam ser vencidas e superadas. Ele almejava uma Igreja viva, atuante no mundo que atravessava tantos desafios econômicos, morais, sociais e espirituais. Aquela inércia na qual a Igreja se encontrava não gerava as transformações que urgiam na Inglaterra naqueles dias.

É interessante notar que Wesley não se opõe à Igreja enquanto instituição; ele defendia a permanência dos metodistas na Igreja Anglicana e lutava pelo seu reconhecimento pela monarquia inglesa; nem contra a instituição Monarquia, porém escreveu tratados contra a escravidão ${ }^{26}$ (1776). Em 1774

\footnotetext{
${ }^{26}$ John WESLEY, "Thoughts Upon Slavery", in The Works of John Wesley on compact disk. Volume XI. Franklin T, N: Providence House Publishers, 1995, p. 59 et. seq.
} 
escreveu um livro chamado: Pensamento sobre a Escravidão, onde expressa sua indignação:

"Metade da riqueza de Liverpool é derivada à execrável soma de todas as vilanias comumente denominadas comércio de escravos. Desejo por Deus que o comércio de escravos nunca mais seja estabelecido. Que nunca mais roubemos e vendamos nossos irmãos como animais, nunca mais os assassinemos aos milhares e dezenas de milhares". ${ }^{27}$

Além de repugnar as condições das prisões da Inglaterra. Não havia condições de um ser racional viver nas prisões, pois faltava quase tudo: água, luz, higiene. O sistema também não tinha intenção de reformar os réus como cidadãos úteis e homens de bem. ${ }^{28}$ Para piorar a situação, os carcereiros não tendo salários estipulado pelo Governo, tiravam o que podiam dos presos. ${ }^{29}$ Wesley foi pela primeira vez numa prisão em 24 de agosto de 1730, visitar os presos com seu amigo Morgan. A partir daí continuou essa prática por quase toda a sua vida, juntamente com os metodistas.

Fato relevante, ainda é que essas visitas também alcançavam os carcereiros que ao ouvirem as pregações se convertiam, como foi Dagge. Este fato interferiu positivamente no dia-a-dia das prisões, pois a cadeia passou a ficar mais limpa: a cada preso ficou a responsabilidade de limpar a cela; as brigas diminuíram, pois os carcereiros se antecipavam para resolver os conflitos; o roubo praticamente deixou de existir, pois sabiam que a sua clausura seria restrita, caso isso ocorresse; a prostituição acabou, pois separaram os homens das mulheres; a ociosidade foi evitada e providenciaram ferramentas para os presos trabalhares; o domingo passou a ser observado. Os detentos não trabalhavam, nem se divertiam aos domingos. Eles participavam do culto público. Passou-se a existir preocupação com a vida espiritual dos presos. ${ }^{30}$ John Howard, uma espécie de

\footnotetext{
${ }^{27}$ LUCCOCK, Halford. Linha de Esplendor sem Fim. p.31.

${ }^{28}$ BUYERS, Paul Eugene. Trechos do Diário de John Wesley, p. 66.

${ }^{29}$ REILY, Ducan. Metodismo Brasileiro e Wesleyano, p. 164.

${ }^{30}$ REYLE, Ducan Alexander. A influência do metodismo revolução social na Inglaterra do século XVIII, p. 13.
} 
secretário de segurança dedicou sua vida à reforma das prisões procurando dar ao preso condição digna de um ser humano. ${ }^{31}$

Wesley em sua trajetória escolheu o caminho da reforma. Na busca do seu potencial podemos compreender a reforma como um papel construtivo em relação à instituição, à sociedade e à religião. Sua decisão em manter o movimento metodista na instituição demonstra maturidade e sabedoria. Entretanto, ficar na instituição não significa acomodar-se, ao contrário, sua intenção era a reforma, a transformação, a revitalização de sua Igreja. Dirigir-se ao indivíduo, mas ao mesmo tempo agregá-lo a um grupo altamente disciplinado e organizado; manter a prática sacramental e chamar o indivíduo a tomar suas decisões; defender o direito dos pobres sem se rebelar contra a monarquia.

Quando John Wesley morreu, um obituário foi publicado a seu respeito na The Gentleman's Magazine, dando-nos uma ideia de como ele era visto pelas classes mais altas de sua época:

"Independentemente de quais que sejam as opiniões geradas pelas ideias, é impossivel negar-lhe o mérito de ter feito um bem infinito às classes mais baixas do povo. Pelos esforços humanitários dele e de seu irmão Charles Wesley, um senso de decência na moral e na religião foi introduzido nas classes mais baixas da humanidade; os ignorantes foram instruídos; os desgraçados, aliviados; e os abandonados, recuperados. (...) Ele enfrentou grande oposição por parte do clero e tratamento grosseiro por parte dos magistrados (...) Ele foi uma das poucas personalidades que sobreviveu à inimizade e aos preconceitos, e recebeu em seus últimos anos de vida toda demonstração de estima de todas as denominações (...) Sua influência pessoal foi maior, talvez, do que qualquer outro cavalheiro do país. Todos os lucros de seus labores literários, tudo que ele conseguiu receber ou coletar (e a somo disso foi imensa) foi dedicado a propósitos de caridade. Em vez de ser um ornamento da literatura, ele foi uma bênção para seus contemporâneos; em vez de ser um gênio de sua época, foi um servo de Deus", ${ }^{32}$

\footnotetext{
${ }^{31}$ NICHOLS, Robert. História da Igreja Cristã. Casa Editora Presbiteriana, 1954, p. 193.

32 Ciitação da The Gentleman's Magazine, abril de 1791, no volume John Wesley de V.H.H. GREEN, p. 152.
} 


\section{4}

\section{Ideias, Princípios e Programas de Educação desenvolvidos por John Wesley: "O Amor é a Essência da Educação"}

Segundo o Bispo Nelson Leite, existiam dois movimentos básicos no coração de John Wesley: o "derramar do amor divino em si, e a dádiva do seu amor em favor do próximo". Por isso desejava compartilhar este amor com toda a força e coração. Amou a todos de modo sincero e sem discriminação, numa época cheia de preconceitos, separações, menosprezos e marginalizações. Em especial amou os abandonados, desprezados, pobres e desesperados, valorizando suas vidas e trazendo-lhes a esperança e o poder do Evangelho de Cristo. ${ }^{33}$

A educação formal nos dias de Wesley era um privilégio usufruído por um grupo muito pequeno: as famílias nobres e os de família rica. Dificilmente uma família pobre, como era o caso dos Wesley (mediante bolsas de estudo ou trabalho) teria essa oportunidade de ir à escola. Assim, a grande maioria do povo era ignorante. O movimento metodista vai contribuir, e muito, na diminuição desta ignorância, especialmente a partir das escolas criadas por John Wesley. Não só na educação para as crianças, mas num destaque especial na educação para os adultos, através de processos diferenciados que pode ser chamado de "educação não formal”. Wesley afirmava:

"Os metodistas podem ser pobres, mas não há necessidade que eles sejam ignorantes". ${ }^{34}$

Essa visão educacional o impulsionou a desenvolver uma imensa atividade libertária, com publicações de toda a espécie, para colocar ao alcance do povo pobre e dos seus colaboradores.

\footnotetext{
${ }^{33}$ Bispo Nelson Leite é Bispo no Brasil e tem participado da vida da Igreja em diversos órgãos religiosos internacionais e nacionais. Esse destaque acima pode ser encontrado no prefácio do livro João Wesley, o Evangelista, de Francis Gerald Ensley, da Coleção Metodismo, 1992, p.9.

${ }^{34}$ John O. Gloss. La Iclesia Cristiana y La Educacion Superior, in: Objetivos de Iãs escuelas metodistas, p. 81.
} 
A educação que Wesley recebeu de seus pais gerou frutos no florescimento do movimento metodista no mundo e no significativo compromisso educacional que ele inspirou em seus seguidores.

Certa vez, escrevendo uma carta para a "Sociedade Pró-Fé e Cristianismo", Wesley disse:

"Embora se deseje mais do que se espera uma modificação do Plano de Educação Moderada, um tratado sobre o assunto, impresso na Inglaterra anos atrás, alcançou sucesso. Apenas alguns têm ousado sair da estrada comum e educar seus filhos de maneira cristã, e alguns orientadores na Universidade têm treinado os que estão sob os seus cuidados de modo digno dos cristãos primitivos". ${ }^{35}$

Suas ideias sobre educação afirma que o aprendizado deve estar ligado ao amor: amor a Deus e ao próximo. E nisso, é suficientemente prático para saber que esses princípios têm implicações específicas para uma vida de disciplina e serviço (mesmo entre as pessoas da universidade).

"Podemos especialmente notar sua equação de piedade com o amor a Deus e avizinhar suas convicções de que o aprendizado deve estar ligado ao amor". ${ }^{36}$

John Wesley produziu diversas publicações sobre educação. No texto Thought on the Manner of Educating Children (1783) reforça a importância da disciplina e da religião para uma boa educação. Ainda em 1783 em um de seus sermões (On the Education of Children), discursa longamente aos pais sobre suas responsabilidades na educação da família, relacionada à carta de sua mãe, sobre métodos educacionais na casa pastoral em Epworth. Além destes, Wesley escreveu e publicou materiais didáticos para o processo educacional como: cinco gramáticas - inglês, grego, latim, alemão e francês, quatro volumes da História da Inglaterra, cinquenta volumes Christian Library e um compêndio de Lógica, entre outros livros didáticos para Kingswood School. ${ }^{37}$

Além das obras acima citadas, John Wesley publicou muitas outras relacionadas ao seu programa educacional. Lançou quase quinhentas obras sobre

\footnotetext{
35 John Wesley, Compêndio de Filosofia Natural, em Albert C. Outler. Theolgy in the Wesley na Spirit, 1957, p. 3-4.

${ }^{36}$ HEITZENRATER, R.P. Santidade e Ignorância Esplêndida: Wesley e a Educação.

${ }^{37}$ Ele produziu cerca de 24 trabalhos para Kingswood School.
} 
os mais diversos assuntos, incluindo A shot story of Rome, Natural Philosophy (em três volumes), e muitos outros. Com intenção de divulgar e distribuir suas publicações aos metodistas, os pregadores (metodistas) com a característica da itinerância peculiar a este ofício, cumpriam um importante papel divulgação dessas obras.

É interessante destacar que não lhe era exigido esse volume de publicação para alcançar seu título na Universidade em Oxford, mas estava tentando, através de seus escritos, educar o povo. Tinha a preocupação em melhorar a mente, por isso sua ênfase educacional, criando escolas e incentivando seus compatriotas a fazerem o mesmo.

Na década de 1720, John Wesley e os metodistas já demonstram a preocupação em apoiar as escolas para as crianças carentes de sua época, apoiando financeiramente à Grey Coat School. Na década de 1730 eles providenciam um professor e suprimentos para crianças órfãs e carentes de uma escola fundada por William Morgan, um dos metodistas de Oxford. Também apoiou um colégio na Geórgia, na América, incentivando seu amigo William Delamotte a ensinar as crianças.

Muitas escolas na Inglaterra o deixavam chocado. Algumas, situadas na cidade grande, onde a corrupção era imensa, muitos colégios não eram seletivos para escolherem professores aptos intelectualmente e em virtude. ${ }^{38}$

Wesley também forneceu curso de aprendizagem acadêmica. ${ }^{39}$ Por isso, pode-se verificar que na organização de Kingswood School, o currículo revela a execução prática dos princípios de Wesley. O curso principal foi projetado para ensinar leitura, escrita, aritmética, inglês, francês, latim, grego, hebraico, história, geografia e cronologia, retórica e lógica, geometria, álgebra, física, música, biografia religiosa, Bíblia e ética. Em seguida, outros assuntos foram adicionados, como: pintura e astronomia.

Quanto à filosofia, parece que Wesley não favorece nenhuma escola de pensamento em particular, como poderia esperar em sua época. Ele avalia este

\footnotetext{
${ }^{38}$ Wesley discute esses problemas em seu "Plain Account of Kingswood School", in The Bicentennial Edition of the Works of John Wesley, v. 13, p.290-292.

39 Este curriculo está mapeado no seu "Plain Account of Kingswood School", ibid, v 13, p. 287-288.
} 
currículo de forma contundente: "quem quer que passe por este curso, cuidadosamente será um acadêmico melhor do que nove em dez dos graduados em Oxford ou de Cambrdge". 40

A educação para Wesley, jamais foi compreendida apenas como instrumento para uma formação intelectual ou para a profissionalização com o fim de adquirir mais bens materiais, ou para crescer na escala social. Nele a educação era um instrumento divino para o humano. Estudar é libertar-se da ignorância e do erro, bem como crescer na graça e no conhecimento de Deus e do mundo criado por ele. Educação, para ele, é descoberta e conquista das riquezas do Criador. Essa compreensão do lugar da educação na economia de Deus nos faz entender o amor de Wesley pela educação.

Segundo John Wesley um dos princípios é que a educação envolve a união do conhecimento e da piedade, da sabedoria e da santidade. $\mathrm{O}$ conhecimento para ele não é um atributo meramente intelectual, mas um canal de auto compreensão, que é determinante para a salvação. A piedade vital não envolve somente uma postura devocional com base no amor a Deus, mas uma extensão social, baseada no amor ao próximo. Por isso para ele "sem amor, todo aprendizado é apenas ignorância esplêndida”. ${ }^{41}$ Aprender e amar estão essencialmente ligados nos objetivos de Deus para a humanidade.

Mas a abordagem de Wesley quanto à educação também envolvia método e disciplina. O programa envolvia um currículo fixo de estudos e regras estritas de operação, semelhante às escolas clássicas da Inglaterra, porém com algumas inovações:

a) Ênfase à compreensão do material que os alunos estudavam, incentivando a reflexão e o entendimento ao invés de uma aprendizagem de repetição.

b) Interesse na educação de adultos.

\footnotetext{
${ }^{40}$ Short Account", p.389. No Plain Accounts, ele diz: "e a respeito do conhecimento das línguas, e das artes e das ciências, com o que quer que seja denominado aprendizagem acadêmica; se aqueles que têm uma capacidade tolerável para elas não avançarem mais aqui em três anos, do que a maioria dos alunos de Oxford ou Cambridge, em sete, carregarei a culpa para sempre". V.13, p. 296.

${ }^{41}$ Alguns estudiosos atribuem esta frase a Agostinho, mas ninguém identificou ainda a fonte real.Wesley torna a questão ainda mais forte numa carta ao Bispo Lowth (10 de agosto de 1780): "Senhor, eu não desprezo de modo algum o aprendizado: eu sei bem o seu valor. Mas o que ele é, particularmente para um ministro cristão, comparado à piedade? Que ele é para um homem que não tenha religião? É como uma jóia no focinho de um porco", in The Bicentennial Edition of the Works of John Wesley, Volume 13, p. 143.
} 
c) Seguindo os passos de sua mãe, promoveu a educação feminina. No decorrer de seu século, a Conferência deu condições financeiras para que meninos e meninas frequentassem à escola.

d) Em sua proposta educacional criou um vínculo estreito entre os pais dos alunos e a escola, em encontros regulares para discutirem o progresso de seus filhos.

e) As turmas eram pequenas para que os alunos pudessem ter contato com os professores em atividades extracurriculares.

f) Além de escolas que funcionavam em regime de internato, como a Kingswood School, ele também criou escolas com horários regulares onde as crianças que moravam perto de suas casas fariam o trajeto diariamente, como Foundery School, em Londres.

g) John Wesley se preocupava com as crianças independentemente da classe social e econômica que viviam. Ele queria colocá-las juntas, na mesma escola. Para ele todos eram filhos de Deus e ninguém estava além da necessidade de aprender. ${ }^{42}$

Segundo Wesley Deus era enfocado na educação, porém se baseava nas pessoas como instrumentos da vontade dEle. Exemplos de mentes e vidas santas, como imitadores de Cristo. ${ }^{43} \mathrm{O}$ professor era o indivíduo chave que deveria ser pessoa de compreensão e piedade. Apesar de todas as regras e regulamentos da escola, sua ênfase deveria ser nas virtudes (valores). Esta combinação: obrigação e virtude ética, ampliando as perspectivas onde as decisões não deveriam ser tomadas simplesmente a partir do certo e do errado, mas em uma escala do bem ao mal. Uma abordagem da virtude se baseia num modelo do bem, impelido pela imitação (referência) e resultados de transformação da vida. Este é o processo de formação espiritual e intelectual.

\footnotetext{
${ }^{42}$ A natureza radical desta suposição é enfatizada pelo projeto de Wesley de instruir os escravos nas plantações da América e com sua conversa pessoal com uma menina escrava na Carolina do Sul. Journal \& Diaries I in The Bicentennial Edition of the works of John Wesley. Volume 18, p.180-181 (23-27 de abril de 1737).

43 "Tendo a mente de Cristo e andando como Ele andou"(ver FI.2:5; 1Jo 2:6) era uma das explicações descritivas continuadas de Wesley sobre a Perfeição do Cristianismo (outro eco da combinação da sabedoria e do amor).
} 


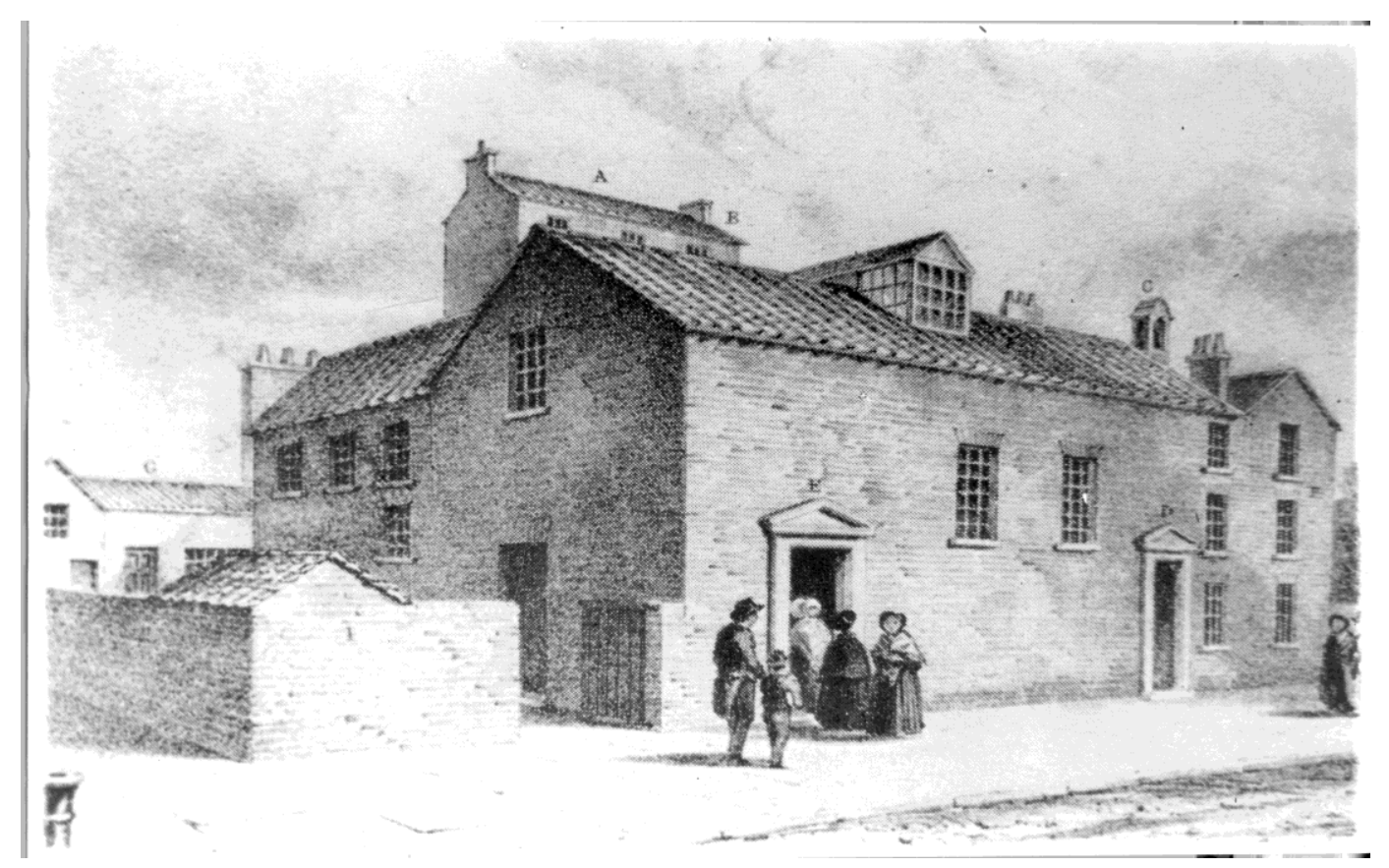

FIGURA 6 - Antiga fundição, comprada por John Wesley e transformada em escola e capela para as classes populares.

Outro destaque do programa educacional de Wesley é que ele envolvia a mudança do indivíduo em sua totalidade: corpo, mente e espírito. Ele desejava que as pessoas superassem sempre os limites do pecado e da ignorância, descobrindo as possibilidades do que poderiam aprender e se transformar. Em sua compreensão, a santidade ou perfeição cristã é o amor puro - amor a Deus e ao próximo, possível a partir da reorganização do ser humano decadente. Ele nunca abandonou essa doutrina da perfeição em sua teologia, nem esse ideal para suas escolas. Heitzerater, analisando a perspectiva da educação em John Wesley, diz:

"A educação pode assim ser vista como um meio de graça pelo qual a perfeição original da criação (uma criatura de sabedoria e santidade), perdida na queda, poderia ser restaurada. ${ }^{44}$

Assim, pode-se afirmar que para Wesley o fim da educação é de algum modo o mesmo que o objetivo da religião: o conhecimento e a piedade vital; a sabedoria e a santidade.

${ }^{44}$ HEITZENRATER, R.P. Santidade e Ignorância Esplêndida: Wesley e a Educação. 
O processo educacional de Wesley nunca buscou massificar, pois compreendia que o mundo criado por Deus é um mundo racional, sensível ao entendimento. Entender e crer são aspectos importantes da mesma realidade.

Ora, a essência da educação e da vida cristã é o amor. Jesus Cristo resume todas as leis e os profetas no amor a Deus e ao próximo, ou seja, amor ao Criador e ao mundo criado. A vida e a obra de John Wesley revelam a manifestação do amor de Deus. Suas mensagens, pregações e todo ensino espelham essa tônica por todos os tempos e lugares.

"A presença de Deus no mundo é graça; sua natureza é graça; a graça é o que Deus é, o que ele sempre é: amor atuante". ${ }^{4}$

Assim, John Wesley afirma o verdadeiro e genuíno cristianismo, verdadeiro e genuíno cristão:

"Lembrando que Deus é amor, o ser humano é feito a sua mesma semelhança. Ele é pleno de amor ao próximo: amor universal, não confinado à seita ou ao partido, nem restrito ‘queles que concordam com ele em opiniões, (...) nem ama somente aos que o amam, (...) amor que abarca vizinhos e estrangeiros, amigos e inimigos; (...) seu amor a todas essas pessoas, como a toda a humanidade é, em si mesmo, generoso e desinteressado, não buscando vantagem para si, nem lucro, nem louvor, nem mesmo o prazer de amar. (...) ele sabe que o "amor social" é absolutamente e essencialmente diferente do "amor-a-si-mesmo" (...) E esse universal, desinteressado amor produz a afeição correta. É abundante em bondade, ternura, sensibilidade, em humanidade, cortesia e afabilidade. (...) Isso produz modéstia, condescendência, prudência, (...) O mesmo amor é gerado de todas as retas ações. (...)”, ${ }^{46}$

Segundo Wesley, o amor de Deus, que requer o amor a Deus e ao próximo, é um poder transformador, curador, regenerador ao mundo e à humanidade. Entretanto, em sua concepção, amor não é um sentimento, mas práxis. Por isso, insistia na absoluta necessidade das obras de misericórdia. Assim, o objetivo mais elevado da pregação e educação deveria ser libertar o ser humano do erro, da ignorância e de todas as formas de pecado. Isso fica muito explicito, quando ele inquiria aos metodistas:

\footnotetext{
${ }^{45}$ Marquardt Klaiber. Viver a Graça de Deus, 1999, p. 81.

46 John Wesley. A Plain Account of Genuine Christianity, conforme Albert C. Outler, p. 184-185.
} 
"Mostras o teu amor pelas tuas obras? Se tens ocasião, (...) fazes de fato bem a todos os homens, vizinhos ou forasteiros, amigos ou inimigos, bons ou maus? Fazes a eles todo o bem que possas fazer, suprindo-lhe as faltas, auxiliando-os no corpo e na alma, no máximo de tuas forças?,"47

Wesley vivia um intenso amor por Deus e por seu próximo. Isso fazia dele o mais perfeito modelo de cristão, com espírito de amor e sacrifício. ${ }^{48}$ Ele insistia que o amor precisava ser experimentado e vivido. Seu coração transbordava de amor: amava as crianças, os pobres, os idosos, os enfermos, os pecadores. E por isso, ele era igualmente amado. Ensinou aos seus seguidores que era muito melhor "levar pessoalmente a ajuda aos pobres do que mandá-la". 49 "Mesmo aquelas pessoas que nada tivessem para dar podiam cumprir sua missão, visitando, e expressando pessoalmente palavras de afeto". 50

Wesley e o movimento Metodista destacam a participação dinâmica de seus seguidores na constante prática do bem. O bem é mais que a ausência do mal e não é necessariamente baseado numa lista de proibições. Assim como virtude, piedade vital ou santidade são mais do que ausência do pecado. Eles estão profundamente ligados a uma orientação fundamental de amor. Ele enfatiza que o sentido na vida cristã expressa-se em amor e serviço. O amor a Deus e ao próximo sempre foi a mola propulsora da mensagem e do ensino de John Wesley.

"Porque havendo ainda amor, mesmo com muitas opiniões errôneas, ele deve ser preferido à verdade despojada de amor. Podemos morrer sem o conhecimento de muitas coisas e sermos, ainda, levados ao seio de Abraão; mas se morrermos sem amor, do que nos valerá o conhecimento?" 51

\section{5}

\section{John Wesley: Teologia e Educação}

As pesquisas sobre a teologia wesleyana concluíram que a base da reflexão de John Wesley está no que se denominou “quadrilátero". Na verdade ele

\footnotetext{
47 John Wesley, Sermões, Volume II, 1954, p. 261.

48 Mateo Leliève. Juan Wesley, Su vida y, su obra, Smith y lamor, 1911, p. 563.

49 John Wesley, The Journal, Volume IV, 1960, p. 422.

${ }^{50}$ Ibid., Volume III, p. 301.

${ }^{51}$ Sermões, Volume I, Prefácio, p. 25.
} 
nunca se referiu a este termo explicitamente, mas Albert Outler, na reconstituição de sua obra, detectou que a constituição do conhecimento de Deus estava organizada em uma estrutura de quatro critérios: Bíblia, Razão, Tradição e Experiência. Os três primeiros oriundos da Igreja Anglicana, da qual Wesley fazia parte. O último, porém foi acrescido por Wesley. A teologia metodista brasileira compreendendo a ênfase da teologia wesleyana e seu compromisso em espalhar a "santidade bíblica por toda a terra", como fundamento do pensamento de John Wesley, acrescentou um quinto elemento ao "quadrilátero wesleyano": a Criação.

a) Bíblia - Wesley considera as Escrituras Sagradas a autoridade mais elementar para a fé e práxis cristã. Seguindo os reformadores, afirmou sola scriptura; e também dizia ser um homem de um só livro, porém dava um amplo sentido a esta afirmação, a saber: A Bíblia deveria ocupar um papel central, mas não exclusivo na vida do cristão. Ela era sua primeira e última norma para estabelecer a validade de qualquer discussão teológica. Entretanto, seria necessária a leitura de outros livros. Por isso criou a "biblioteca cristã" para os pregadores metodistas. Ele mesmo afirmava: "Sem ler intensamente, ninguém pode ser um pregador profundo, nem tampouco um cristão completo".

Wesley experimentou em seu tempo a pesquisa exegética da Bíblia, influenciado principalmente por Johannes Bengel. Identificado pelos reformadores do século XVI, Wesley procurou destacar o sentido literal das Sagradas Escrituras, em oposição à interpretação exclusivamente alegórica. Em sua aproximação com o texto sagrado havia a preocupação em dar sentido contextualizado para seus ouvintes.

Wesley foi um literalista (conceito distinto da expressão moderna do "literalismo" fundamentalista), onde ratificava a concepção exegética onde a Bíblia era vista como um relato infalível (distinto também do termo "inerrantista", tal qual compreendemos na atualidade). Ao mesmo tempo em que Wesley considerava as Escrituras vindas de Deus, como suas palavras e vontade, reconhecia também a participação humana em sua composição. Assim, para ele a Bíblia era a Palavra de Deus, com as 
palavras humanas. Não faltou em Wesley o empenho para dar sentido ao texto sagrado libertando do puro literalismo para inseri-lo na vida dos metodistas e do povo.

Como meio de graça, as Sagradas Escrituras deveriam ser lidas regularmente e individualmente pelos metodistas visando o aprofundamento da fé. Entretanto, isso não extinguia o valor e a importância da leitura bíblica comunitária, nas sociedades metodistas. Wesley buscou preservar verdades mais gerais da fé da Igreja, em detrimento de conceitos e opiniões menores. Também orientou os pregadores metodistas que utilizassem linguagem simples para maior compreensão do povo, pois a Bíblia deveria ser devolvida aos seus destinatários.

A leitura da Bíblia não deveria se restringir a obter informações das Escrituras, mas deveria ser transformada em "ato de misericórdia" (solidariedade), em favor dos pobres e marginalizados.

b) Razão - Na razão residem riquezas e riscos. Riqueza, na medida em que permite à experiência religiosa maior objetividade e consistência, por outro lado, o risco de encontrar-se na redução da razão o único meio para o conhecimento de Deus.

Wesley, mesmo tendo sido influenciado profundamente pelo Iluminismo nunca colocou o valor da razão como pressuposto da fé. Em contra partida, por conta de seus atritos com os cristãos entusiastas ${ }^{52}$ (fanáticos) sempre preocupou-se com a possível negação da razão por estes.

Depois das Sagradas Escrituras, a razão foi o critério mais utilizado por Wesley visando aferir a veracidade dos postulados da fé. Para ele renunciar a razão seria o mesmo que renunciar à religião. Ambas deveriam caminhar lado a lado. ${ }^{53}$

\footnotetext{
${ }^{52}$ A palavra "entusiasmo" não faz hoje justiça ao termo Enthusiasm recorrentemente usados nas ilhas britânicas do século XVIII. O mais acertado seria traduzi-la por fanatismo, seu equivalente semântico mais próximo.

${ }^{53}$ Trechos da carta de Wesley endereçada a Thomas Rutherforth, em 1768, Citado por Williams, C. op. cit. p. 20.
} 
Em uma carta escrita ao senhor Ruthenforth sobre uma das escolas metodistas, Wesley argui:

"O senhor continua: "É princípio fundamental da escola metodista que todos os que entram para ela devem renunciar a sua razão". Está o senhor acordado? A menos que o senhor esteja conversando dormindo, como pode o senhor dizer uma inverdade tão grosseira? Nós temos o princípio fundamental de que o renunciar da razão é renunciar à religião. Que a razão e a religião caminham de mãos dadas, e que toda religião sem razão é falsa". ${ }^{54}$

c) Tradição - Wesley, seguindo os padrões anglicanos, refere-se a tradição fazendo menção aos pais pré-nicenos, devido à proximidade destes com os apóstolos, bem como à natureza indivisa da Igreja ${ }^{55}$, e aos padrões doutrinais da Igreja Anglicana: 39 Artigos de Religião, as Homilias e o Livro de Oração Comum. ${ }^{56}$

A tradição revela que ninguém vive sua fé isoladamente. A cada geração está posto o desafio de transmitir esta herança (depositum fidei).

d) Experiência - A novidade do método teológico de Wesley era a ênfase empírica, ou seja, uma inédita valorização da experiência humana. ${ }^{57}$

"O acréscimo da "experiência" foi uma inovação metodológica significativa. Wesley introduziu explicitamente um componente empírico na argumentação teológica antigamente dominada por um apelo a três autoridades: as Escrituras, a tradição e a razão".

Uma das características mais marcantes do metodismo primitivo se deu na ênfase que o ser humano deveria ter uma experiência pessoal com Deus. Essa novidade trouxe muitas críticas e acusações ${ }^{58}$. Em resposta, Wesley afirmou que a

\footnotetext{
${ }^{54}$ Cartas, Volume V, p. 364.

${ }^{55}$ WILLIAMS, C . op. cit., p. 19.

${ }^{56}$ Wesley, J., Sermões, p. 112.

${ }^{57}$ Theodore Runyon. A Nova Criação. A Teologia de Wesley Hoje, 2002, p. 35.

58 Os metodistas foram acusados de serem calvinistas, uma vez que enfatizavam "excessivamente" a graça de Deus e não a necessidade de obras para alcançar-se a salvação. Imediatamente relacionado a isto, a imputação de antinomianismo a John Wesley devido ao fato de este ter pregado a justificação somente pela fé. Cf. RACK, H. D. Reasonable Enthusiast, p. 278.
} 
experiência pessoal com Deus não segue uma uniformidade quanto às suas manifestações externas:

“...há uma variabilidade irreconciliável nas operações do Espírito Santo nas almas dos homens. (...)muitos o encontram derramando-se sobre eles como uma torrente. (...), mas ele opera em outros de maneira muito diferente. Ele exerce a sua influência de maneira delicada, refrescante como o orvalho silencioso."

John Wesley procurava conciliar de forma equilibrada o júbilo com o juízo, o sentimento com a inteligência, o arrebatamento do entusiasmo com o governo da razão. ${ }^{60}$ Toda a experiência com Deus deve levar ao compromisso com Deus e com a sua vontade, isso significa que, independentemente da variedade, a relevância da mesma será firmada na medida em que, estando fundadas nas Escrituras Sagradas, como sua referência normativa determinante, produza amor genuíno por Deus e pelos seres humanos. ${ }^{61}$

Pode-se dizer que Wesley foi um notável pregador e um extraordinário professor. Buscava alcançar a compreensão possível da fé cristã. Ele compreendia Deus como um ser de amor e inteligência. É certo que o pecado havia destruído a imagem do amor e sabedoria de Deus no ser humano. John Wesley mesmo afirmava:

\footnotetext{
"Além da semelhança com o seu Criador, o homem foi dotado de entendimento - capacidade de aprender todas as coisas, que se lhe antolham, e de fazer julgamento a respeito dos mesmos. ${ }^{62}$ (...) A imagem natural de Deus consiste nesses elementos: o poder de movimento próprio, o entendimento, a vontade e a liberdade". ${ }^{3}$
}

Ora, o pecado corrompe a totalidade do ser humano, então a graça, o livre amor de Deus reconstrói o caminho da reconciliação com Ele. O ponto de partida

\footnotetext{
${ }^{59}$ BURTNER, R., CHILES, R. Coletânea da Teologia de John Wesley, p. 89

${ }^{60}$ CAMARGO, G. B., op. cit., p. 30-31.

${ }^{61}$ Williams, C. La Teologia de Juan Wesley, p. 24

${ }^{62}$ John Wesley. Sermões: A Libertação Geral, conforme citado em Burtner e Chiles: Coletânea, p. 110.

${ }^{63}$ Op. cit, p. 111.
} 
é a Graça Preveniente. Em seguida, a Graça Justificante, que convida o ser humano ao arrependimento, e finalmente a Graça Santificadora que o convida a caminhar em novidade de vida a partir de Cristo Jesus. Assim o ser humano vitaliza a sua semelhança e imagem de Deus. Em Cristo a dignidade é refeita. Coração e razão trabalham em sua plenitude.

É notório que tanto na pregação quanto no ensino Wesley privilegiava a práxis. Isso não significa que desprezava a teoria, a formulação de preceitos ou a sistematização de princípios, mas cria que a teologia deveria ser uma reflexão sobre a prática cristã. A prática deveria estar além das especulações, teorias ou intelectualismo. Nesse sentido distingue entre "opiniões" e "doutrinas essenciais". Essas estão relacionadas à prática da fé no cotidiano.

As doutrinas essenciais são aquelas que interferem não apenas com a crença de alguém, mas na sua conduta, seu comportamento e seu modo de viver em relação a Deus, ao próximo e a si mesmo. Elas supõem: confiança, segurança, firmeza e convicção. Já as opiniões são meros "pontos de vista", suposições, possibilidades. Assim, Wesley e o Metodismo reforçam a prática da fé, do bem e das boas obras como critérios da própria identidade e validação. Esse assunto será aprofundado posteriormente.

Wesley valorizou a teologia da cultura na medida em que encontrou elementos essenciais para desenvolver sua mensagem e ensino. A partir da realidade concreta da vida do povo enxergou os desafio, cujas respostas ele buscava na Bíblia e na vasta formação cultural que havia construído. A teorização posterior, a construção da teologia nada mais era que a organização da forma racional dos elementos da vivência da fé cristã e da vida humana.

Wesley era um teólogo profundamente enraizado no seu mundo, vivendo e ensinando um cristianismo contextual. Para isso, precisava fazer um exame nos costumes enraizados na Igreja oficial:

"Depois de tudo quanto as Escrituras e a razão disseram, tão excessivamente plausiveis são as pretensões em favor da religião solitária, em favor de se porem os cristãos fora do mundo, ou pelo menos, de ocultarem os cristãos que se encontrem em meio do mundo, que necessitamos de toda a sabedoria de Deus para percebermos o laço, e de todo o poder de Deus para escaparmos a 
ele, de tal modo são fortes as objeções que se têm engendrado contra a vida social, aberta e ativa dos cristãos". ${ }^{64}$

Ao longo se sua caminhada, Wesley foi reformulando suas tradições na medida de suas experiências práticas: ele aprendera que pregar ao ar livre era profanação da Palavra de Deus, até que descobriu ser um espaço para a manifestação da graça divina; aprendera que somente o clérigo consagrado poderia pregar a mensagem, até que os leigos provaram na prática que isso era uma bênção de Deus.

Wesley tem a convicção que a pregação e a educação, a mensagem e o ensino são a base para a edificação e consolidação da nova vida em Cristo. Essa convicção teológica faz Wesley insistir na necessidade da educação. Ele é um pregador que educa e um educador que prega.

A educação é tão marcante no movimento metodista que ao espalhar-se pelo mundo se empenhava para libertar o ser humano de toda a ignorância.

\section{6}

\section{O Povo: O Alvo da Educação Metodista em John Wesley}

A educação formal das classes pobres sempre foi uma das principais preocupações de Wesley. Os pobres não tinham acesso à educação na Inglaterra no início do século XVIII. Ser pobre significava permanecer analfabeto. As poucas instituições existentes possuíam baixo nível moral e corrompiam mais que instruíam as crianças. Por outro lado a Igreja vivia um tempo de total inércia, enclausurada em seus próprios templos, mera cumpridora de seus rituais vazios, ignorando por completo a realidade em seu entorno: a pobreza, a exploração dos trabalhadores nas minas de carvão, a fome, o alcoolismo, o êxodo rural, o desemprego, o analfabetismo, a imoralidade, a falta de esperança e perspectiva diante das mudanças, tendo como pano de fundo a Revolução Industrial. Seus

\footnotetext{
${ }^{64}$ John Wesley. Sermão XXIV. Sobre O Sermão do Monte, in, Sermões de Wesley, v. II, 1985, p. 509-510.
} 
ministros realizavam as celebrações dominicais, mas seus sermões eram vazios e insípidos. Os fiéis, por sua vez, frequentavam os cultos como rotina semanal, como um espaço social para encontro dos amigos, ou meramente para desfilarem suas roupas e ornamentos. A maioria da população pobre, não frequentava as celebrações dos cultos dominicais, nem tinha acesso às escolas.

Vê-se essa autêntica preocupação de John Wesley com os pobres durante toda a sua vida. Esse aspecto pode ser facilmente verificado em seus escritos e traços biográficos. A composição dos grupos metodistas era predominantemente de pessoas pobres. Assim pode-se afirmar que o metodismo primitivo era composto por pobres e que seu principal líder, John Wesley, possuía uma preocupação especial com as crianças.

Nas obras de Wesley (sermões, notas, cartas, anotações pessoais) encontram-se a citação da palavra "pobre" 1.448 vezes $^{65}$. Dentre elas cerca de 1.000 vezes referindo-se a condição socioeconômica do povo. Comparado a outras palavras encontradas em seus escritos, o termo nos indica uma tônica em sua visão. A palavra "salvação" é encontrada 945 vezes; "culto" - 940; Evangelho - 879; misericórdia - 783; piedade - 186; louvor - 573 e redenção 267. Acima de 1000 citações: Deus - 12.693; Cristo - 3.236; Espírito (Santo e também humano) 2.963; pecado 2.222; graça - 1612; céu - 1.379; oração - 1.174 .

A partir dessa compreensão pode-se perceber que o cotidiano no qual a teologia wesleyana foi forjada, foi marcada por uma relação concreta com pessoas, grupos e famílias pobres. Wesley critica a opressão econômica, luta contra a escravidão e valoriza a participação das mulheres nas sociedades metodistas. Ele valoriza a ação humana no processo de santificação e libertação. Entretanto esta ação não se resume numa prática de ajuda emergencial aos necessitados, mas nas causas dos males sociais. A pobreza não era vista como destino ou inércia pessoal. Sua prática em favor dos pobres revelava sua perspectiva teológica baseada na unidade orgânica onde o encontro pessoal com Cristo possibilitado pelo Espírito Santo prevê o compromisso de uma vida de

\footnotetext{
${ }^{65}$ Estudo do Prof. Dr. Cláudio Ribeiro, no texto Wesley e os Pobres, na obra: Teologia e Prática na Tradição Wesleyana, Editeo, 2005, p. 179.
} 
amor e serviço. Nessa unidade, a misericórdia e a justiça tornam-se fatores ativos e preponderantes para a fé. Ou seja, expressão da "verdadeira religião".

A ética cristã deve ser marcada pela solidariedade e partilha. Ele advertia os ricos que os mesmos deveriam deixar de crer que são melhores que os pobres e os exortava para que deixassem de gastar o dinheiro com veneno (coisas vãs) para dar aos pobres, ou ainda, que eram loucos e cruéis por guardarem dinheiros em cofres, enquanto alguns irmãos pobres passavam necessidades. Para ele, a grande maioria dos ricos estava debaixo de maldição especial de Deus, pois estão roubando não somente a Deus, mas aos pobres também.

Baseado no Evangelho de Mateus 25. 40 "\Quando fizeres a um desses meus pequeninos a mim o fizeste", enfatiza a importância de dar com retidão de coração. Sua ética cristã é a ênfase de partilhar com os pobres os bens, que de fato, pertencem a Deus; dando pão ao faminto, roupas aos desnudos, hospedagem aos estrangeiros, auxílio para quem está encarcerado, sendo bons mordomos de Deus e dos pobres.

O versículo de Mateus 26:11, que afirma: "Os pobres sempre tereis convosco" será enfatizado por John Wesley diversas vezes, com ênfases específicas:

No Sermão 88, de 1766, John Wesley afirma que essa expressão bíblica nos exorta de que sempre temos que ter dedicação e cuidado com os pobres.

Em 1777, no Sermão 99, a expressão é compreendida no sentido de que temos que estar sempre com os pobres. Não se pode esperar para exercer a misericórdia, os necessitados estão diante de nós.

Em 1790, no Sermão 119, um ano antes de sua morte, Wesley afirma que a expressão bíblica também está no sentido de conhecermos a realidade dos pobres e de ter em conta naquilo que se deve fazer, fundamentalmente em seu favor.

Essa perspectiva em Wesley é muito significativa especialmente considerando-se que os pobres sempre estiveram à margem da história. Por isso, na busca de soluções para minimizar o impacto dos problemas sociais de sua época e da ineficiência da educação de seu tempo, John Wesley realizou um 
estudo sobre o sistema inglês e diagnosticou diversas fragilidades: má localização das escolas e número excessivo de alunos, crianças de má formação moral, currículo falho, ensino religioso deficiente. Como fruto dessa preocupação com a educação para os pobres, em 1748 surge a Kingswood School, para atender os filhos dos operários das minas de carvão. Ele escolheu o contexto dos pobres como referencial e construiu ao redor das necessidades dessa população o movimento metodista. Wesley desejava e trabalhava incansavelmente para reformar a nação, especialmente a Igreja e para espalhar a santidade bíblica por toda a terra. Nesta "construção da reforma", buscava garantir um espaço para essa população empobrecida. Isso não significa dizer que as elites estavam excluídas do projeto de Deus na terra, mas a própria elite se excluía de participar das reformas necessárias. Ele, diversas vezes dirigiu-se aos representantes seculares e eclesiásticos na busca da reforma da nação e da Igreja. Seu foco primeiro era o pobre e para isso dedicava sua vida.

Segundo Baez Camargo, o metodismo foi, em uma palavra, o primeiro grande movimento moderno de educação de adultos.

A teologia, a mensagem, o ensino e a vida de John Wesley são totalmente voltados para o povo, na sua absoluta maioria, para o pobre. Sua mensagem e ensino sempre foram veiculados de modo claro, simples. Objetivo, a fim de que ao ouvi-lo, a população pudesse compreendê-lo e praticá-lo. Nesse sentido Outler o identifica como um "teólogo do povo".

O notável preparo intelectual e educacional de John Wesley definiu e norteou as ênfases do Metodismo. É certo afirmar que o maior beneficiado deste movimento foi o povo; principalmente os marginalizados, pobres e ignorantes. $\mathrm{O}$ Metodismo tornou acessível e compreensível ao povo a oferta da graça libertadora de Cristo. Wesley dizia:

“...escrevo como geralmente falo, isto é, para o povo - ad populum: à massa humana, aqueles que nem apreciam, nem compreendem a arte de falar. " 66

E ainda:

"Ambiciono a verdade simples para o povo simples: assim de propósito deliberado, abstenho-me de todas as especulações delicadas e filosóficas, de

\footnotetext{
66 John Wesley, Sermões. Volume I, 1953, Prefácio, p. 25.
} 
todos os arrazoados embaraçantes e intrincados. (...) Trabalho por evitar todas as palavras que não sejam fáceis de entender". ${ }^{67}$

O compromisso de Wesley com o povo o faz organizar as sociedades metodistas, com suas capelas e escolas, a fim de tornar as pessoas livres do erro, da ignorância e do pecado. A mensagem era pregada e ensinada nas ruas, nas praças, com pregações ao ar livre, nos lares; endereçadas às crianças, jovens, adultos. Isso ocorria nas cidades, nos caminhos, nas zonas rurais, em toda a parte.

Naquela época os livros custavam muito caro, sendo impressos em prensas manuais e a composição era feita em tipografia muito rudimentar. Os livros tinham capas duras para protegê-los melhor. Contudo, Wesley era um homem muito pragmático. Como precisava melhorar o "sistema de distribuição dos livros" que era realizada pelos pregadores metodistas, diminuindo o peso que carregavam e diminuindo os custos dos livros, tornando-os mais acessíveis para o povo: Wesley inventou a encadernação em brochuras.

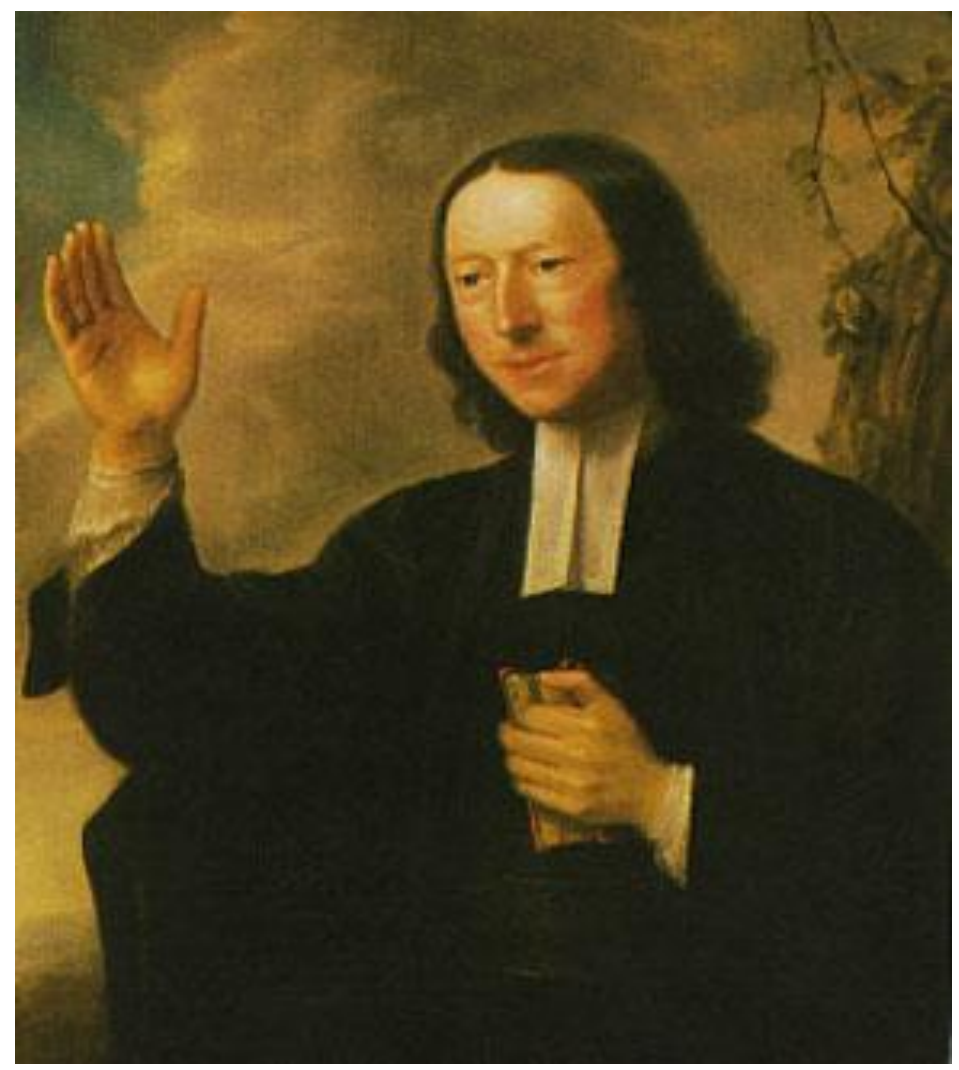

FIGURA 7 - John Wesley pregando ao ar livre. Uma pintura de Hone.

\footnotetext{
${ }^{67}$ Ibidem, p. 21-22
} 


\title{
3
}

\section{A Educação Metodista e seus Modelos Pastorais no Novo Mundo}

\begin{abstract}
"O Sir. Benjamim Ighan, de Queen's College, Oxford, o Sir. Charles Delamotte, filho de negociante em Londres, que se tinha oferecido a alguns dias antes, meu irmão Charles Wesley e eu tomamos condução para Gravesend, com o fim de embarcar para a Geórgia. O motivo que nos levou a deixar nossa terra natal, não era fugir à privações (Deus nos havia dado bastantes bênçãos materiais), nem ganhar o refúgio de riquezas ou de honras, mas simplesmente isto - salvar a nossa alma: para vivermos exclusivamente para a honra e a glória de Deus. $\grave{A}$ tarde encontramos o navio Simomonds e embarcamos imediatamente" ${ }^{68}$
\end{abstract}

\section{1 \\ O primeiro surgimento do metodismo na Geórgia: Século XVIII}

Com a morte de seu pai, Samuel Wesley em 1735, John Wesley concordou em ir para Epworth, onde seu pai era pároco, mas o Bispo de Londres recusou a intermediação de Sir John Phillips para esta substituição. Após alguns meses voltou para Oxford e logo foi procurado por John Burton, que lhe convidou para ir à Geórgia onde dariam assistência aos colonos e pregariam aos indígenas.

Wesley partiu para o Novo Mundo na certeza que obedecia o chamado de Deus e que veria a propagação do Evangelho por toda a terra. Reconheceu também, que a graça de Deus é uma força verdadeira na história; que somos movidos pela ação de Deus e tudo que fazemos vem da providência divina para fins libertadores.

Entretanto, empreender uma viagem à vela para o Novo Mundo no século XVIII, não era uma tarefa simples. John Wesley nunca havia estado em um navio e desde a sua juventude havia abominado o mar. Wesley ficou

\footnotetext{
${ }^{68}$ Diário de John Wesley: Terça-feira, 14 de outubro de 1735.
} 
profundamente impressionado com as poderosas tempestades do Atlântico. A nua realidade da morte iminente mostrou a fragilidade do seu senso de segurança. Ele estava com medo da morte, não queria morrer, mas envergonhava-se em admitir isso. "Oh! Quão puro de coração deve ser aquele que tem como regozijar-se em apresentar-se diante de Deus sem aviso prévio." Wesley via seu medo da morte como "falta de fé".

"Altas horas da noite, acordei-me com o rugido do vento, fiquei assustado; tal susto me revelou que eu tinha medo de morrer." ${ }^{\text {" } 99}$

Faltando uma semana para avistarem a terra, ocorreu a mais violenta das três tempestades que enfrentou. $\mathrm{O}$ mar se derramava sobre o navio, a vela mestra não resistindo, partiu e as águas corriam pelo convés. Os ingleses gritavam desesperados, porém os moravianos cantavam salmos, sem intervalo. Wesley ficou tremendamente impressionado com a fé dos moravianos diante da morte. Ele jamais havia visto tanta calma e segurança. Passada a tempestade procurou um dos alemães moravianos para descobrir qual era o segredo para tanta confiança diante da morte. Wesley percebeu que não possuía fé em seu coração. Desse modo, como poderia pregar? Foi então que Pedro Böller o aconselhou: “Wesley, não deixe de pregar porque pensa que não tem fé. Pregue sobre a fé até que a obtenha, e depois de obtê-la, continue a pregar." Assim o moço se sentiu encorajado a não desistir de seus propósitos na Geórgia.

No dia 06 de fevereiro de 1736 ele pisa na Geórgia pela primeira vez. Continuou tendo contato e a influência dos moravianos. Iniciou seus contatos com os indígenas. Não foi fácil estabelecer contato com eles, especialmente pelas experiências anteriores de missões evangelizadoras: ingleses, espanhóis e franceses. $\mathrm{O}$ cacique tinha muitas reservas quanto ao cristianismo, especialmente por experiências desastrosas de imposição do Evangelho.

Tomochichi (um dos chefes) e Sinauky (rei da nação Savannah) o convidaram para conhecer sua aldeia. Porém quando os irmãos Charles e John Wesley chegaram lá, cinco dias depois, não encontraram ninguém. A missão com

${ }^{69}$ Diário de John Wesley: Domingo, 23 de novembro de 1735. 
os indígenas começou meio vacilante. Apesar de tudo, haveria um grupo em Savannah que iria formar um núcleo para o programa tipicamente metodista de enriquecimento espiritual. Seus planos era fazer deste núcleo um grupo que se reunisse para ler, orar, cantar salmos em conjunto, encontrando-se nas noites de quarta e sexta-feira e aos domingos à noite. John Wesley também passou a ter encontro aos sábados à noite com os comungantes.

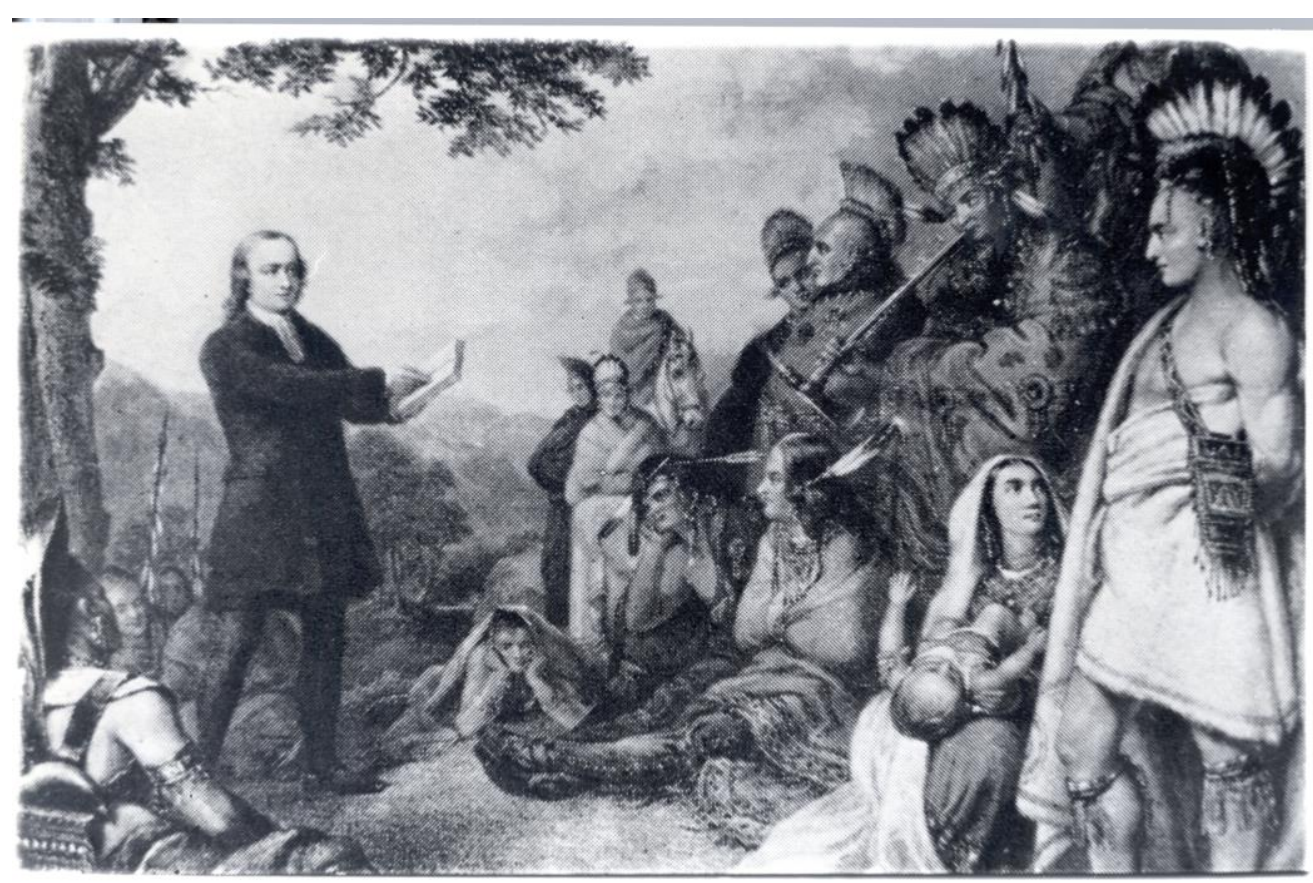

FIGURA 8 - Charles Wesley pregando aos índios americanos.

Tentou o mesmo trabalho em Frederica, mas este não teve o mesmo êxito.

O interesse de Wesley pela a educação dos jovens, evidente no trabalho dos metodistas em Oxford, continuou na Geórgia com o envolvimento metodista na escola em Savannah. Charles Delamotte era professor. Ele não apenas ensinava as crianças a ler, escrever e fazer contas, mas dava instruções de catecismo aos mais jovens, antes das aulas, pela manhã, e aos mais velhos depois da escola. Wesley catequizava a todos, aos sábados e antes das orações vespertinas dos domingos à tarde. Também tinha grande interesse nas aulas de Miss Hopkey e Miss Bovey, as quais ele ensinava línguas e teologia.

A presença nos cultos públicos havia crescido paulatinamente desde a sua vinda, reunindo cerda de sessenta a oitenta pessoas. Outro destaque importante era um atrativo exclusivo de cultos na Geórgia: o uso de hinos. Wesley 
havia publicado uma Coleção de Salmos e Hinos, em 1737. O primeiro hinário publicado na América. Esses textos, muitos traduzidos do alemão, expressam o coração de um pietismo baseado nas Escrituras Sagradas, e esclarecem os temas que Wesley considerava fundamental, como: a completa dependência da graça, a centralidade do amor, e o desejo do fogo genuíno de Deus capaz de inflamar o coração frio.

John Wesley enfrentou muitos dissabores e calúnia, o que encurtou seu tempo naquele continente. Permaneceu menos de dois anos nessa missão na Geórgia, retornando para seu berço, na Inglaterra. Ele havia chegado com grandes expectativas e a deixou com amargura e desapontamento:

"Eu sacudo o pó dos meus pés e deixo a Geórgia, depois de haver pregado o Evangelho lá... não como devia, mas como fui capaz". ${ }^{70}$

"Nos comunicamos com dois navios que estavam saindo do porto(...) minha mente agora encheu-se de pensamentos(...): Fui à América para converter os indios; porém, oh! quem me converterá? Quem, quem será aquele que me livrará deste coração vil de incredulidade? Tenho boa religião de verão; posso conversar bem, sim, e sinto-me seguro quando não há perigo perto; mas basta a morte olhar-me no rosto, meu espírito fica perturbado. Não posso dizer: Morrer é lucro". ${ }^{71}$

Tempos mais tarde o movimento metodista voltaria a este solo e fincaria sua bandeira.

\section{2 \\ O Legado Teológico e Doutrinário de Wesley para os Metodistas}

Em sua busca religiosa, John Wesley inicialmente busca o caminho da experiência mística, onde o indivíduo tem encontro face a face com o sujeito exemplar, Deus. ${ }^{72}$ Essa experiência face a face não ocorreu automaticamente para ele, apesar de sua exigência. Suas incertezas e incapacidades de realizar aquilo que julgava ser a vontade de Deus geravam constantes crises no seu interior.

\footnotetext{
${ }^{70}$ Diário de John Wesley: Sexta-feira, 02 de dezembro de 1737.

${ }^{71}$ Diário de John Wesley: Terca-feira, 24 de janeiro de 1738.

72 O elemento do olhar face a face é muito importante no NT, mas também aparece já na bênção araônica (Nm. 6:22-26).
} 
Pode-se dizer que passou pela crise do início da modernidade, pelo silêncio de Deus. Em seus contínuos autos exames, John Wesley registra as suas falhas mas exige de si, o que Touraine define como: comportamento típico do sujeito moderno - "(...) a capacidade de resistir às pressões do hábito e do desejo para submeter-se somente ao governo da razão". ${ }^{73}$

Nesta fase, em 1729, Wesley apreende um conselho de um amigo, que seria precioso para sua busca: "O indivíduo precisa não somente de Deus, mas de outro ser humano para chegar até Deus". ${ }^{74}$ A comunhão humana não substitui a procura de Deus, mas ajuda na sua continuação. Wesley relatou sua experiência pessoal com Deus datada em 24 de maio de 1738, citada no primeiro capítulo desta dissertação. Entretanto, o destaque proposto aqui baseia-se em sua afirmação: "O Evangelho de Cristo não conhece outra classe de religião, só a social; nenhuma outra santidade que não seja a santidade social". Nesse ponto, vê-se dois lados dessa comunhão: aquela que contribui para o amadurecimento pessoal e o seu desdobramento, para uma atividade propositiva na sociedade. Essa compreensão gerou algo extraordinário: a experiência face a face com o pobre. Essa foi uma das marcas mais profundas do metodismo nascente. Certa vez Wesley disse que conhecia mais os pobres do que qualquer outro inglês da sua época, em seu país. A partir desse encontro contínuo, Wesley desenvolveu uma sensibilidade solidária que se tornou um princípio organizador dos metodistas. Esta organização social, segundo John Wesley, tinha a vocação de servir a Deus e a obrigação de servir aos pobres. $\mathrm{O}$ sistema administrativo deveria representar a graça, a justiça, a misericórdia e a paz.

Para ele, o papel do indivíduo é participar ativamente na busca da graça de Deus, usando os meios da graça e construindo a fraternidade, deixando o mal e fazendo o bem.

Segundo Hinsor, sistematizava seu método teológico da seguinte forma:

\footnotetext{
${ }^{73}$ Alain Touraine. Crítica da Modernidade. John Wesley enfatiza o uso instrumental da razão e tentou reconciliar as propostas dos racionalistas (platonistas de Cambridge) e dos empiristas (aristotelianos de Oxford).

${ }^{74}$ Thomas Coke e Henry Moore. The lifem of the Rev. John Wesley. London: printed by G. Paramore, 1792 p.54 e p.55.
} 
"Na superficie Wesley parece ser todas as coisas a todos os homens. Com o protestantismo clássico, ele aceita a Bíblia como autoridade final. Com o protestantismo sectário, ele dá ênfase ao testemunho interior do Espírito Santo. Com o Pietismo, ele insiste na importância da experiência pessoal. Com a tradição católica ele dá um importante lugar à tradição, especialmente a tradição da Igreja não dividida. Com os reformadores ele insiste na salvação só pela fé. Com os racionalistas, ele insiste no papel essencial do raciocínio". ${ }^{75}$

Esse posicionamento não representa um ecletismo, mas um esforço para fazer justiça a todos os elementos em nosso conhecimento de Deus - "Conhecereis a verdade..." (João 8:32).

Wesley escreveu "... cremos que a palavra escrita de Deus é a regra única e suficiente para a fé prática, e nisto somos fundamentalmente distinguidos da Igreja Romana." ${ }^{16}$ Ele concordava com os Reformadores no princípio de "sola Scriptura", no sentido de que a Escritura é a autoridade final com respeito a fé e a prática cristã. Porém, ele afirmava que a Bíblia não é a única fonte do nosso conhecimento de Deus, é necessária também, a experiência pessoal.

Este mesmo equilíbrio wesleyano direciona essa prática cristã para a Igreja, onde precisa existir um povo ligado na pregação da pura palavra de Deus. "... integrado em Cristo pelo batismo, animados pelo amor, unidos por toda sorte de companheirismo e disciplina", onde a ministração dos sacramentos produzem a resposta da fé que cria a santidade da vida, não uma Igreja apenas para alguém ouvir a pregação, participar dos sacramentos ou assistir o culto.

\section{3 \\ Principais Doutrinas Metodistas}

\subsection{1}

\section{Doutrina do Pecado}

Apóstolo São Paulo, Santo Agostinho e Martinho Lutero têm grande importância na formação do pensamento de Wesley sobre seu conceito do homem, especialmente pela sua incapacidade de salvar-se. Wesley é também

\footnotetext{
75 HINSOR, Willian J. A Dinâmica do Pensamento de Wesley. São Bernardo do Campo, SP: Imprensa Metodista, p. 11 e 12.

${ }^{76}$ HINSOR, Willian J. ibid, p. 12.
} 
acusado de tendências pelagianas por sua crença no livre-arbítrio. Na relação de Deus com o homem ele prioriza a graça, ou seja, Wesley combina um "pessimismo da natureza" a um "otimismo da graça".

Em seu sermão sobre o pecado original, Wesley apresenta vários textos que o suportam em sua posição sobre o homem mergulhado no pecado: "A Escritura afirma que "pela desobediência de um só homem todos se tornaram pecadores" [Rm. 5:19]; que "em Adão todos morreram" [I Co. 15:22], morreram espiritualmente, perderam a vida e a imagem de Deus; que Adão, pecador decaído "gerou um filho à sua própria semelhança [Gn. 5:3] e nem lhe era possível gerá-lo de outra forma, pois quem pode tirar uma coisa pura de alguma coisa impura?" [Jó 14:4]. Consequentemente, nós, bem como os outros seres humanos, estávamos mortos em delito e pecado [Ef. 2:1], "sem esperança e sem Deus no mundo" [Ef. $2: 12]^{77}$. Para Wesley, o cristão tem que ter consciência de sua doença, tem que ter resposta para as perguntas: "É o homem, por natureza cheio de todo tipo de mal? Está vazio de todo o bem? Está ele totalmente decaído? Toda sua alma está corrompida? Ou, para voltar ao texto, está "toda a imaginação dos pensamentos do seu coração má, continuamente”? Admitindo isso, você é Cristão quanto a esse ponto se doutrina. Negando-o você é ainda pagão no pensamento" ${ }^{78}$ No final deste sermão, Wesley fecha dizendo: "Conheça sua doença! Conheça a cura! Você nasceu em pecado; portanto, importa nascer de novo." 79

Mesmo para os que já eram convertidos, Wesley coloca que "Há em toda pessoa, mesmo depois da sua justificação, dois princípios contrários: natureza e a graça - chamados pelo apóstolo São Paulo de "carne e espírito”. Daí serem mesmo as crianças santificadas em Cristo, embora o sejam apenas em parte.(...) De modo que os crentes são exortados continuamente e que estejam vigilantes contra a carne, o mundo e o diabo. A experiência constante dos filhos de Deus comprova isto. Enquanto sentem o testemunho em si mesmos sabem que a vontade não está totalmente submissa a vontade de Deus. Sabem que estão nele,

\footnotetext{
${ }^{77}$ WESLEY, John. Sermões (Tradução de Ducan A. Reily) Vol. I - O Despertar do Pecador. São Paulo: Imprensa Metodista, 1984, p. 22,23.

${ }^{78}$ WESLEY, John, Ibid, p. 35.

${ }^{79}$ WESLEY, John, Ibid, p. 37.
} 
mas o seu coração está pronto a desertar; tem uma tendência para o mal em muitos dos seus aspectos e a voltar as costas ao bem". ${ }^{80}$

\section{3.2 Doutrina da Justificação}

Em sua doutrina da salvação, Wesley trabalha também dois conceitos centrais: justificação e santidade. Para ele a justificação é a "porta da salvação" onde ocorre o perdão de Deus, a libertação da culpa e do castigo dos nossos pecados. Ser justificado é a aceitação pela misericórdia de Deus. A santificação é um dom de Deus, um fruto da justificação, o fim do domínio do pecado pela obra do Espírito Santo, renovação pelo poder de Deus.

Conforme o próprio Wesley nos diz em seu sermão sobre “A Justificação pela Fé”: “A clara noção bíblica de Justificação é o perdão de pecados. É o ato de Deus Pai, pelo qual, em atenção à propiciação feita pelo sangue de seu Filho, “mostra sua justiça (ou misericórdia), pela remissão dos pecados passados". ${ }^{81}$ Esta é a concepção natural lógica, apresentada por São Paulo através de toda epístola. Assim, é que ele expõe, principalmente no capítulo seguinte: “Bemaventurados aqueles cujas iniquidades são perdoadas e cujos pecados são cobertos; bem-aventurado é o homem a quem o Senhor não imputará pecado”, “que acarrete sua condenação. ",82

Sua doutrina de salvação fundamenta-se na obra histórica de Deus em Jesus Cristo e sua obra presente através do Espírito Santo, fundamentando-se a justificação do homem através da morte de Jesus Cristo como propiciação pelos nossos pecados, reconciliando assim o homem com Deus, o que não quer dizer que o Espírito Santo não esteja presente nessa experiência e que cria a disposição do coração, chamada fé. Esta obra do Espírito Santo é absolutamente necessária

\footnotetext{
${ }^{80}$ BURTHER, Robert W., CHILES, Robert E. Coletânea da Teologia de J. Wesley. São Bernardo do Campo, SP: Imprensa Metodista, 1960. p. 178.

${ }^{81}$ WESLEY, J. Sermões de Wesley - Volume I (Trad. Nicodemos Nunes). São Bernardo do Campo, SP: Imprensa Metodista, 1981. p. 113.

${ }^{82}$ Este sermão está baseado na Epístola do Apóstolo S. Paulo aos Romanos 4:5.
} 
para nossa salvação porque Ele nos "guia em toda a verdade e santidade, equilibrando a obra de Deus, o filho de Deus e o Espírito Santo."

Wesley equilibra em sua doutrina da salvação o testemunho do Espírito com os frutos. Enfatiza a necessidade da experiência com o Espírito Santo, testificando que somos filhos de Deus e que como consequência disso, produzimos os frutos do Espírito: amor, alegria, paz, ... descrito em Gálatas 5. 22 e 23.

Wesley reconhece que todo homem para crer na salvação e para crescer na santidade precisa receber o Espírito Santo. O Espírito Santo passa à frente, prepara o caminho, mas o homem deve andar no caminho "até que Deus do modo como lhe apraz, diz a seu coração: Tua fé te salvou, vai-te em paz". Wesley coloca de forma bem clara que isto não é "obra" do homem, mas de Deus, ele nos diz que: "Não convém que os pobres vermes culpados e pecaminosos, que de graça recebem todas as bênçãos de que desfrutam (desde a menor gota de água que lhe umedece a língua até as riquezas imensas da glória eterna), tudo por mero favor e não como direito, peçam a Deus as razões de sua conduta. Não nos faz honra o interrogarmos aquele que "não dá contas de nenhum de seus caminhos", inquirindo: "Por que fizeste da fé a condição, a única condição de justificação? Porque decretaste: o que crê, e somente este, será salvo?" Este é justamente o ponto sobre qual São Paulo tão fortemente insiste no IX capítulo desta Epístola, isto é, que os termos do perdão e aceitação dependem, não de nós, mas daquele que nos chamou; que não há injustiça em Deus, quando estabelece suas condições, não de acordo com os nossos, mas de acordo com seus próprios desejos. Deus pode mui justamente dizer: "terei misericórdia com quem eu quiser ter misericórdia", ou seja, com o que crê em Jesus. "Assim, pois não é do que deseja, nem do que corre", o escolher as condições sob as quais encontrará aceitação, "mas de Deus, que mostra misericórdia"; que não aceita o pecador por nenhuma outra forma, a não ser por um gesto de seu livre amor, de sua bondade imerecida. "Por isso tem misericórdia de quem Ele quiser ter misericórdia", isto é, 
daqueles que crêem no Filho de seu amor; "e a quem Ele quer", isto é, àqueles que não crêem, "Ele os rejeita", abandonando-os, afinal, à dureza de seus corações". 83

Para Wesley está claro que a justificação vem pela fé, sem obras como condição prévia de justificação, mas essas obras são o fruto imediato daquela fé pela qual somos justificados, Wesley dá uma advertência aos Metodistas: "guardate sobre tudo deste laço do diabo - o permaneceres numa fé oposta à santidade e a salvação! Se dás importância a essa espécie de fé - estás perdido para sempre; tu ainda edificas tua casa sobre a areia."

Wesley encerra o sermão sobre “A Justificação pela Fé” com o seguinte parágrafo:

"Quem és tu, que vês agora e temes tua impiedade intima e exterior? Tu és o homem! Desejo-te para meu Senhor! Ambiciono-te para Filho de Deus pela fé! o Senhor precisa de ti. Tu que temes estar destinado ao inferno, estás, na realidade, destinado a crescer na glória de Deus, na glória de sua livre graça, justificando o ímpio e o que não possuía obras. Oh! Vem depressa! Crê no Senhor Jesus, e tu, sim, tu, serás reconciliado com Deus!" ${ }^{84}$

\section{3.3 \\ Doutrina da graça}

Wesley equilibra a iniciativa de Deus e a resposta do homem. Deus opera por sua graça e o homem deve aceitar com arrependimento e fé verdadeira a dádiva da graça de Deus. Wesley diz que o homem não tem mérito nem pode ter orgulho em sua salvação. Deus e o homem cooperam sob o propósito e vontade redentora de Deus. Em seu primeiro sermão pregado na Universidade de Oxford, Wesley quase atinge a posição calvinista quando diz "de vós mesmos não vem a vossa fé, nem vossa salvação; são dons de Deus; representam livre e imerecida dádiva. A fé, mediante a qual sois salvos, bem como a salvação que Deus por sua própria vontade e por seu mero favor adicionado a ela, procede do Senhor". Wesley conserva seu equilíbrio pela rejeição da ideia de que esta graça seja

\footnotetext{
${ }^{83}$ WESLEY, J., Sermões de Wesley, p. 119-120.

${ }^{84}$ WESLEY, J., Ibid., p. 121.
} 
irresistível. Em outro sermão "sobre realização de nossa própria salvação", Wesley faz duas afirmações: "primeiro: Deus opera em vós; portanto podeis trabalhar. Do contrário isto seria impossível... Segundo: Deus opera em vós, portanto, deveis trabalhar..." Já Santo Agostinho afirma: "aquele que nos fez sem nós, não nos salvará sem nós" ${ }^{\prime 85}$. Deus não tira nosso entendimento, fortalece; não tira a liberdade de optarmos pelo bem ou mal, não nos forçou. Assim evita os dois extremos: da predestinação determinista do Calvinismo e do sinergismo humanista do pelagianismo, que nega o pecado original e a corrupção da natureza humana.

Dentro de sua definição, a graça de Deus é que gera a condição que o ser humano, pecador por natureza, participador do pecado original, que tornou-se morto, cadáver, e como um cadáver não tem condição de trazer vida a si mesmo. Este Deus por Sua Graça, imerecida de nossa parte, efetua sua ação restauradora e vivificadora. A esta ação de amor Wesley chama de graça preveniente; vem dEle e é Deus que age primeiro:

"Nossa ação em relação a Deus é sempre uma resposta ou um responso à
iniciativa divina Deus é como a mãe Galinha que junta os pintinhos debaixo
das suas asas (Mt. 23:37) ou uma ursa que protege com fúria seus ursinhos
que correm perigo (Os. 13:8). Se nós o amamos, é porque Ele nos amou
primeiro." 86

"Tudo na fé é obra da graça. Por isso, acentuamos: "sola gratia". Mas também acrescentamos: "num quam sola". Ela nada destrói. É como se disséssemos: Solus creator - num quam solus. Devemos, portanto, inserir também na fé os "componentes" humanos. Apenas ocorrerá que estes são "componentes" mínimos ao lado do "componente" divino, como Deus e a criatura perfazem um "todo" incomensurável. Afirmar isto não significa diminuição nem da realidade divina nem da realidade da criatura, nem da distinção real que existe entre ambas. Pelo fato de este "todo" assim relacionado ser para nós um mistério e não se ajustar com facilidade às nossas ideias, nem por isso, há razão para o rejeitarmos

\footnotetext{
${ }^{85}$ BURTHER \& CHILES, Coletânea da Teologia de J. Wesley, p. 150.

${ }^{86}$ Revista Em Marcha - Volume II - Estudos Doutrinários do Metodismo (Coord. Warren C. Wafford). São Bernardo do Campo, SP: Imprensa Metodista, s/d. p. 22.
} 
teologicamente. É o homem que crê, não Deus por ele, ou em seu lugar! (...) Pois precisamente o que há de principal na fé, consiste em ser ela uma resposta ao apelo pessoal de Deus, um "sim" dado à salvação do homem, uma vez que o Deus que nos chama é o Deus "salutaris noster", o Deus interessado na salvação do homem e em fazer-lhe a auto comunicação do seu amor., 87

\section{3.4}

\section{Doutrina da fé}

Wesley usou o texto do Apóstolo São Paulo que diz: "Pela graça sois salvo mediante a fé"... (Ef. 2:8), para pregar um de seus sermões que tem como título "A Salvação pela Fé”. Neste sermão ele determina em suas posições qual é a fé que salva:

1. "Não é meramente a fé dos pagãos, posta em Deus como governador moral".

2. Não é a fé intelectual do demônio.

3. Não é a fé dos Apóstolos, antes da ressurreição (de Jesus).

4. Mas a fé em Cristo, de coração, fé na propiciação. (...) é uma Salvação presente, livre do pecado, da culpa, do temor e do poder do pecado." 88

Nesta doutrina da fé, Wesley coloca sua fé e estimula a outros, por exemplo, quando diz: "Vai com coragem, criancinha que crês em Cristo, a sua "mão direita te mostrará terríveis coisas"! Embora estejas desamparado e sejas fraco como um recém-nascido, o homem forte não será capaz de permanecer em face de ti. Tu prevalecerás contra ele, e o subjugarás e o dominarás, e o porás debaixo de teus pés. Sob o comando do grande Capitão de tua salvação,

\footnotetext{
${ }^{87}$ FEINER, JOHANNES \& LOGHRER, MAGUNS. Lyterium Salutis - Compêndio de Dogmática Histórico-Salvífica. Petrópolis: VOZES, 1978. p. 50-51.

${ }^{88}$ WESLEY, J., Sermões de Wesley - Vol. II, p. 29.
} 
marcharás "conquistando e vencendo, até que todos os teus inimigos sejam aniquilados, e "a morte seja tragada na vitória". 89

Na doutrina da fé, tem sem dúvida o seu lugar devido: "sola gratia". (...) Contudo, o Deus da graça, o Espírito de Santificação, não é outro senão o próprio Deus Criador, sempre presente ao lado de sua obra. A salvação vem ao encontro do homem criado por Deus. Ela possibilita e faz com que se realize (embora não forçando) uma autêntica opção pessoal. Sua luz faz com que o homem dotado de raciocínio possa "ver". Seu impulso faz com que o homem livre (sem perda nem prejuízo da sua liberdade) dê seu assentimento na fé. A fé é "supra-racional", sim, mas não é irracional. (...) Na fé, a graça não entra em concorrência com as forças naturais do homem. Antes, liberta-as em direção ao supremo apelo. Ela não degrada o homem que tem fé relegando-o a condição de robô. Não elimina nenhuma responsabilidade interna e pessoal do homem, mas imprimi-lhe, de fato, a liberdade. $^{90}$

A fé em Wesley é trabalhada no sentido de evidência (certeza) das coisas não vistas. Em seu sermão sobre "O modo escriturístico da Salvação" ele traz a argumentação de São Paulo que nos diz: "Deus, que ordenou que a Luz brilhasse nas trevas, brilhou em nosso coração para dar-nos a Luz do conhecimento da glória de Deus no rosto de Jesus Cristo”. Em outra parte o mesmo apóstolo fala dos "olhos do nosso entendimento sendo abertos". Por esta dupla operação do Espírito Santo, tendo os olhos da nossa alma abertos e iluminados vemos as coisas que o "olho natural não viu nem o ouvido ouviu". ${ }^{91}$ A fé, portanto, não é um aceitar vazio de que "Jesus é o Cristo", ou simplesmente aceitar as doutrinas e dogmas da Igreja, do Antigo ou Novo Testamento; não é meramente aceitar que "Deus existe" ou mesmo testificar que Jesus saiu de Deus. Até aí é uma fé morta! “A fé verdadeira, viva e cristã, sendo nascidos de Deus todos que a possuem, isto não é apenas um assentimento, um ato do entendimento, mas uma disposição que Deus operou no seu coração, uma "confiança segura em Deus que, pelos méritos de Cristo, os seus pecados são perdoados e ele é reconciliado ao favor de Deus."

\footnotetext{
${ }^{89}$ WESLEY, J., op.cit., p. 41-42.

${ }^{90}$ FEINER, JOHANNES \& LOGHRER, MAGUNS, op. cit., p.49.

${ }^{91}$ BURTHER \& CHILES, Coletânea da Teologia de J. Wesley, p. 158-159.
} 
Isto implica que o homem primeiramente renuncia a si mesmo; que, para ser "achado em Cristo", ser aceito através dele, totalmente rejeita toda a "confiança na carne"; que "nada tendo com que pagar", não possuindo nenhum merecimento pelas suas obras, nem justiça de qualquer espécie, ele (sic) chega-se para Deus como pecador perdido, miserável, autodestruído, autocondenado, desfeito e desamparado.” (...) juntamente com uma completa conviç̧ão, tal qual nenhuma palavra pode expressar, do que somente de Cristo vem a nossa Salvação e um desejo sincero dessa Salvação, deve preceder a fé viva, a confiança nele que “pagou por nós pela sua morte e cumpriu por nós a lei em sua vida.", 92

"Wesley cria que Deus oferecia o dom da fé a todos que arrependidos, a buscassem. Não achava que era uma experiência rara e só para os especialmente favorecidos. (...) Eles (Charles e John Wesley) logo descobriram que a experiência seguia se repetindo entre amigos e entre o povo em geral, depois de George Whitefield começar a buscar os trabalhadores e os pobres no seu próprio ambiente, proclamando a mensagem de Deus ao ar livre. Os irmãos Wesley, não sem muito temor e tremor, logo seguiram seu exemplo, com resultados surpreendentes!" 93

\section{3.5 Doutrina da perfeição cristã}

A Doutrina da perfeição cristã de Wesley foi ensinada através de seus sermões, de suas notas sobre o Novo Testamento e até dos hinos que ele cantava, e que seu irmão escrevia ou mesmo em cartas e poesias. Wesley coloca alguns pontos fundamentais sobre a Salvação:

"Primeiro: Não somente admitimos, mas sinceramente refutamos que haja, nesta vida, uma perfeição que implique na dispensa da obediência de todos os mandamentos de Deus ou da prática do bem a todos os homens enquanto temos tempo, especialmente aos domésticos da fé. (...)

\footnotetext{
92 BURTHER \& CHILES, op.cit., p. 162 et.seq.

93 Revista Em Marcha - Vol. II - Estudos Doutrinários do Metodismo (Coord. Warren C. Wafford), p. 33.
} 
Segundo: Cremos que não há, nesta vida, tal perfeição que implique na libertação completa da ignorância ou do erro nas coisas não essenciais à Salvação, das muitas tentações ou das inumeráveis fraquezas com as quais o corpo corruptível mais ou menos sujeita a alma. Não podemos encontrar base nas Escrituras para supormos que qualquer habitante de uma casa de barro esteja totalmente isento quer das fraquezas corporais quer da ignorância de muitas coisas, ou para imaginarmos que alguém seja incapaz de erro ou de cair nas diversas tentações...".94

Dentro desta posição, Wesley traz uma resposta sobre o que quer dizer sobre o homem perfeito. "Queremos significar aquele em quem existe a mente que houve em Cristo e que anda como Cristo andou; um homem que tem as mãos limpas e um coração puro, o que foi lavado de todas as impurezas da carne e do espírito, aquele que não é motivo de tropeço para os outros, e aquele que de fato não comete pecado. (...) Entendemos que seja aquele a quem Deus santificou totalmente o corpo, a alma e o espírito, aquele que anda na luz como Ele está na luz, em quem não há nenhuma treva, tendo sido lavado de todo o pecado pelo sangue de Jesus Cristo seu Filho." 95

Sua posição é bem firme com relação a estes propósitos e justifica na Palavra suas posições. "Vós, portanto, sereis perfeitos como é perfeito o vosso Pai que estás nos céus". "E quem diz: Vós não sereis, ou, pelo menos não sereis enquanto a vossa alma não se separar do corpo? É doutrina de S. Paulo, S. Tiago, S. Pedro, e de S. João, e não poderia ser outra a do Sr. Wesley e de todos os que pregam o evangelho puro e total". 96

Em 1769, Wesley colocou pontos fundamentais sobre a perfeição cristã, num tratado publicado para as sociedades metodistas. ${ }^{97}$

\section{Principais pontos da Perfeição Cristã:}

1) Existe a perfeição, pois ela é constantemente citada nas Escrituras.

\footnotetext{
${ }^{94}$ WESLEY, J. Coletânias da Teologia de João Wesley, p. 209.

${ }^{95}$ WESLEY, J., Ibid, p. 210.

${ }^{96}$ WESLEY, J.. Ibid., p. 211.

97 Estes pontos encontram-se de forma mais abrangente nos sermões de Wesley, Notas introdutórias do Sermão XL - A Perfeição Cristã, p. 271-274.
} 
2) Ela não vem cedo como a justificação, pois as pessoas justificadas precisam "prosseguir para a perfeição" - Hebreus 6:1.

3) Não é tão tardia quanto a morte, pois São Paulo nos fala de homens vivos que eram perfeitos - Fl. 3:15.

4) Não é absoluta. A perfeição absoluta não pertence ao homem, nem aos anjos, mas somente a Deus.

5) Ela não torna o homem infalível: ninguém é infalível enquanto está no corpo.

6) É ela sem pecado? Não vale a pena contendermos a respeito de termos. Ela é "Salvação do Pecado".

7) É “amor perfeito" - I Jo 4:18. Este é a essência da mesma. As suas propriedades ou frutos inseparáveis são: alegria constante, oração sem cessar e em tudo darmos graças - I Tes. 5:19 ss.

8) Não podemos prová-la. Não pode de maneira nenhuma permanecer como um ponto indivisível, ser incapaz de desenvolvimento, pois uma pessoa aperfeiçoada em amor pode crescer na graça muito mais ràpidamente do que o fazia antes.

9) Pode ser perdida. Temos muitos exemplos disto. Mas não tínhamos inteira convicção disso até cinco ou seis anos atrás. ${ }^{98}$

10) É constantemente precedida e seguida de um trabalho gradual." 99

Em um dos hinos de Charles Wesley, "Grande Amor" (293 do Hinário Evangélico), em inglês, possui o título “Love Divine, All Loves Excelling” (32), encontramos uma exposição poética da doutrina da Perfeição Cristã. ${ }^{100}$

Destacamos aqui os pontos principais deste hino. A Primeira estrofe: Enaltece o divino amor que excede todo o amor humano que é o fundamento da nossa Salvação.

\footnotetext{
${ }^{98}$ Este sermão foi escrito e publicado em 1741, conforme informação nas notas introdutórias no livro acima mencionado.

${ }^{99}$ WESLEY, J., Op. cit., p. 212.

${ }^{100}$ Revista Em Marcha - Vol. II - Estudos Doutrinários do Metodismo (Coord. Warren C. Wafford). Op. cit., p. 57.
} 
(...) “Fixe em nós Tua habitação” (...)

"Coroa todas as tuas misericórdias" (...)

Segunda estrofe: Enfatiza a presença e a ação do Espírito Santificador. A versão brasileira, "Vem remove o mau (não o "meu" desejo) traduz bem o inglês, falando do coração do qual Deus remove não só o pecado como erradica a sua raiz.

Terceira estrofe: Da $3^{\underline{a}}$ estrofe em inglês nada aparece na versão em português. Mas na versão original, cada linha fala da perfeição.

"Deixa-nos receber toda a Tua vida."

"Nunca mais abandone o Teu templo" (...)

"Queremos sempre Te louvar e Te servir" (...)

"Orar e louvar-Te sem cessar";

"Gloriar-nos em Teu amor perfeito."

Estas três últimas frases nos lembram I Ts. 5: 16-18, texto chave para entender o pensamento Wesleyano sobre a perfeição. Visto no sentido global, o trecho se refere a um estado de comunhão ininterrupta com Deus e uma submissão alegre e íntegra à Sua vontade, características importantes da perfeição cristã.

Quarta estrofe: A última estrofe relaciona-se integralmente à perfeição cristã.

"Completa, então, Tua nova criação;

Torna-nos puros e imaculados." (...)

"Deixa-nos ver tua grande Salvação,

Perfeitamente restaurado em Ti."

É a grande Salvação. Não a simples, ou seja, não apenas justificado, mas a perfeição: não mera restauração, mas uma restauração perfeita, até da imagem de Deus, tão danificada pela queda.

A conclusão inevitável é que John e seu irmão Charles Wesley ensinavam ao povo metodista as principais ênfases doutrinárias do movimento, através das pregações, estudos, publicações e dos seus hinos. Não só ensinavam 
essas doutrinas aos metodistas, mas garantiam sua divulgação por toda a parte onde os metodistas atuavam e atuariam". ${ }^{101}$ (33)

John Wesley encerra o sermão sobre a "Perfeição Cristã" trazendo a Palavra que Deus deu a Moisés:

"O Senhor teu Deus circundará o teu coração, e o coração de tua descendência para amares o Senhor teu Deus de todo o coração e de toda a tua alma, para que vivas." (Dt. 30:6).

Ou mesmo por Davi, no Salmo 51:10:

"Cria em mim, ó Deus, um coração puro e renova em mim um espírito reto."

"E mais notavelmente por Ezequiel, naquelas palavras:

"E derramarei sobre vós uma água pura, e sereis purificados de todas as vossas impurezas e de todos os vossos ídolos, Eu vos purificarei. E dar-vos-ei um coração novo, e porei um novo espírito em meio de vós; $e$ farei que vós andeis nos meus preceitos e que guardeis as minhas ordenanças e que as pratiqueis. E vós sereis para mim o meu povo, e Eu serei para vós o vosso Deus. E também vos salvarei de todas as vossas impurezas. Isto diz o Senhor Deus: No dia em que Eu vos tiver purificado de todas as vossas iniquidades, - os gentios conhecerão que Eu, o Senhor, restabeleci os lugares arruinados; Eu o Senhor, o disse e Eu o farei." (Ez.31:25ss).,102

\section{4 \\ O Metodismo nos Estados Unidos da América, a morte de John Wesley e os novos rumos do Metodismo: Rupturas Inevitáveis}

Vinte e cinco anos após a primeira experiência de Jonh Wesley em solo americano, os primeiros metodistas chegaram aos Estados Unidos por volta de 1760 a 1766. Entretanto, os primeiros missionários enviados por John Wesley aportam no país por volta de 1770 .

\footnotetext{
${ }^{101}$ WESLEY, J. Sermões de Wesley - Volume II, p. 292

${ }^{102}$ WESLEY, J. , op. cit., p.302
} 
Um ano após a declaração dos Estados Unidos de independência da Inglaterra, o metodismo americano se separa do metodismo inglês, constituindo nos Estados Unidos uma Igreja autônoma: a Igreja Metodista Episcopal. Tal fato ocorreu na "Conferência de Natal". Esta reunião durou de 24 de dezembro de 1784 a 2 de janeiro de 1785. Este "concílio" foi importante não só pelo fato de oficializar a autonomia do metodismo americano, mas por estabelecer características que vão marcar o metodismo nos Estados Unidos da América. Destaca-se como um desses elementos a ênfase sobre a educação, simbolizada por uma escola cujo nome foi criticado por John Wesley. Tratava-se da junção do nome de dois bispos metodistas: Francis Asbury e Thomas Cocke, derivando o Cockesbury College. Quando Wesley soube da Conferência, enviou uma carta para os seus ex-superintendentes que agora estavam nos Estados Unidos, dizendo:

"Eu estudei para ser pequeno, vocês estudaram para serem grandes; eu lutei para ser pequeno, vocês trabalharam para serem grandes; eu fundei uma escola, vocês fundaram um colégio e, ainda, deram a este seus próprios nomes." 103

O Cockesbury College e todo o movimento educativo metodista nos Estados Unidos a partir de Cocke e Asbury, estará voltado para a formação de determinadas classes sociais, como as elites e as classes médias superiores, enquanto as escolas fundadas por Jonh Wesley atendia especialmente os pobres. Aqui já se vê uma ruptura teológico-pastoral do metodismo primitivo inglês para aquele que se configuraria no solo americano.

O Colégio Cockesbury foi autorizado a funcionar, e em 1787 foi inaugurado em Abingdon Maryland. Ele durou somente alguns anos, sendo incendiado por duas vezes. Entretanto, seria o início de muitas escolas e colégios que viriam, trazendo uma imensurável contribuição para o cristianismo da América

Antes de sua morte de sua morte Wesley escreveu a Ezekiel Cooper em Filadélfia: "Não perca a oportunidade de declarar a todos os homens que os

${ }^{103}$ Revista do COGEIME. Ano 2, 1993. Texto do Dr. Peri Mesquida, p.36. 
metodistas são um único povo em todo mundo; e que estão firmemente determinados a assim continuar" (JWL, 8: 260).

Estas palavras soavam como falsas no panorama do metodismo americano. Há muito tempo a Igreja Episcopal dos Estados Unidos mostrava-se independente de Wesley e dos ingleses. Uma série de atitudes intencionais demonstrava que a nova denominação estava livre do controle britânico, como: as modificações em relação ao modelo britânico contidas na sua primeira Forma de Disciplina em 1785, a revogação da Minutes obrigatória logo depois, a escolha da nomenclatura para a função episcopal, a inclinação do próprio Asbury de chamar Wesley, de um modo um tanto irreverente, de "nosso velho pai", dentre outras, assinalava a futura posição dos metodistas americanos - movidos por um amor familiar pelo legado de John Wesley, porém não mais dependentes da liderança patriarcal britânica. Os pregadores americanos poderiam estar contentes em pregar as doutrinas Wesleyanas, mas estavam felizes por terem se libertado do seu controle político. O processo de separação que na prática começara na década de 1780 continuou depois da morte de Wesley, tipificado pela Conferência Americana que aprovou em 1792 uma nova ordem de culto, deixando de lado o "Culto de Domingo" que Wesley havia enviado.

Uma semana após sua morte, Wesley foi enterrado às 5 horas, atrás da Capela na City Road. Cerca de vinte amigos mais chegados estavam ali ao lado de seu túmulo. O desejo de Wesley foi seguido de acordo com uma prescrição escrita, feita há muito tempo, a qual especificava que seis pessoas pobres deveriam levar seu corpo ao túmulo, e que a cada uma delas fosse dada uma libra. 


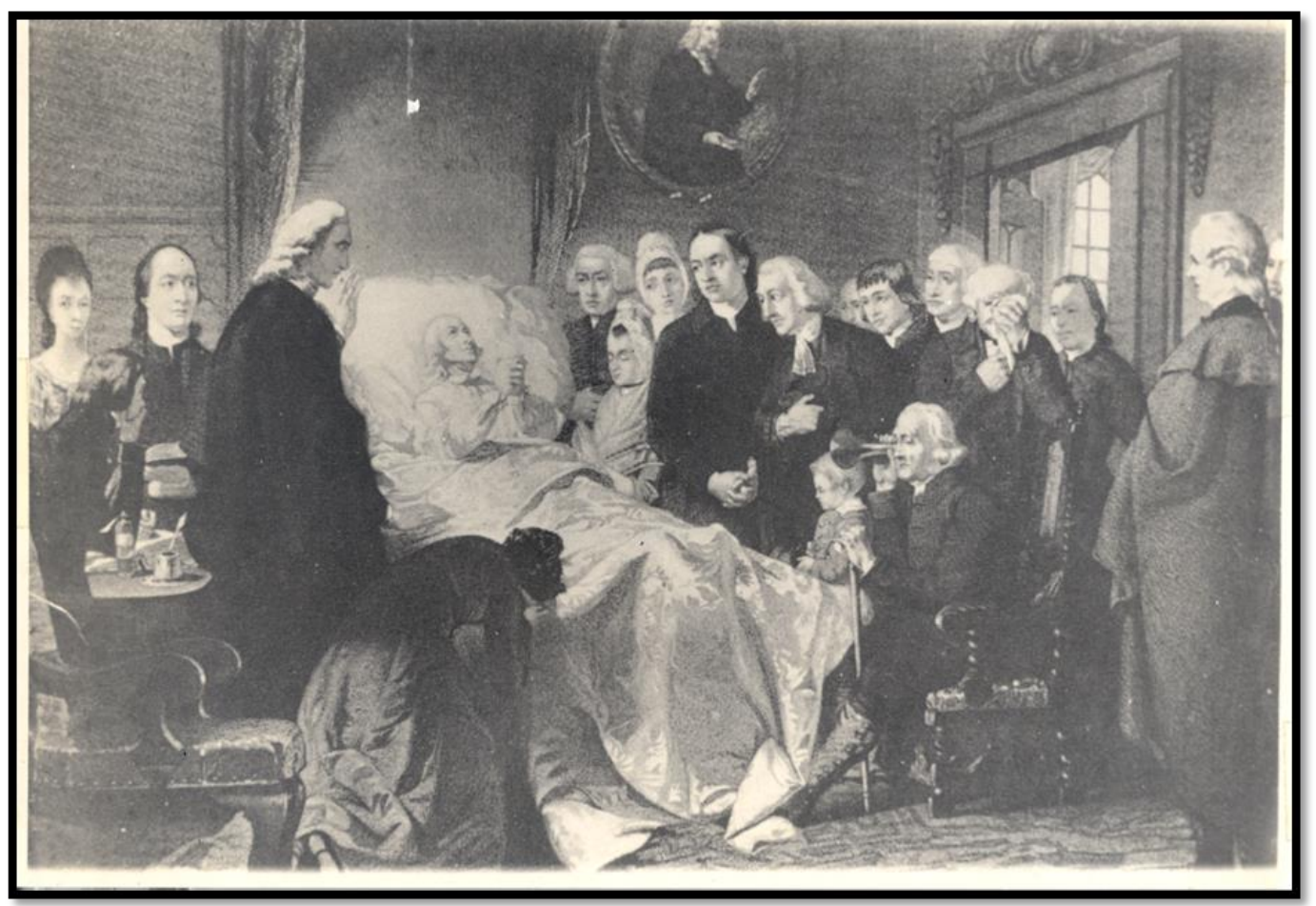

FIGURA 9 - Quadro pintado por Marshal Claxton, exibido pela primeira vez em 1842, na Royal Academy. O pintor mostra os últimos momentos de John Wesley com seus amigos e parentes, quando exclama: "O melhor de tudo é que Deus está conosco".

Wesley também havia pedido que fosse realizada uma cerimônia simples, "sem pompa, exceto pelas lágrimas daqueles que me amaram e que estão me seguindo para o seio de Abraão" (JWJ 8:343). Em seguida, às 10 horas da manhã ocorreu o culto público na Capela, acompanhado pela multidão. O sermão fúnebre foi feito por seu médico pessoal, Dr. John Whitehead. Este sermão foi impresso em poucas horas e lido nos púlpitos metodistas nos dias que se seguiram, em todas as ilhas britânicas.

Um obtuário elogioso foi publicado na The Gentleman's Magazine, que dá uma ideia de como ele era visto pelas classes mais altas de seus contemporâneos:

Independentemente de quais sejam as opiniões geradas por suas ideias, é impossivel negar-lhe o mérito de ter feito um bem infinito às classes mais baixas do povo, pelos esforços humanitários dele e de seu irmão Charles Wesley, um senso de decência na moral e na religião foi introduzido nas classes mais baixas de humanidade; os ignorantes foram instruídos; os desgraçados, aliviados; os abandonados, recuperados (...) Ele enfrentou grande oposição por parte do clero, e tratamento grosseiro por parte dos magistrados (...) Ele foi uma das poucas personalidades que sobreviveu à inimizade e aos preconceitos, 
e recebeu em seus últimos anos de vida toda a demonstração de estima de todas as denominações (...) Sua influência pessoal foi maior, talvez, do que de qualquer outro cavalheiro desse país. Todos os lucros de seus labores literários, tudo que ele conseguiu receber ou coletar (e a soma disso foi imensa) foi dedicado a propósitos de caridade. Em vez de ser um ornamento da literatura, ele foi uma bênção para os seus contemporâneos, em vez de ser o gênio de sua época, ele foi o servo de Deus. ${ }^{104}$

Nas Conferências que se seguiram uma série de tensões, tendências, preocupações e interesses se intensificaram. A preocupação em manter a unidade dos metodistas era realizada com muitos obstáculos. Na Conferência de 1796 deixou-se margem para a base de formação da Nova Conexão Metodista, uma nova denominação que surgia, com dois pregadores e cinco mil metodistas que os seguiram. Esse processo continuou durante todo o século seguinte, com vários outros grupos tornando-se independentes a fim de preservarem um ou outro princípio fundamental que julgavam ser essencialmente metodista ou wesleyano.

Wesley liderou o Metodismo primitivo até 1791, ano de sua morte. Segundo Novaes, depois disso os metodistas criaram uma estrutura fechada onde o governo deveria estar nas mãos daqueles que se destacavam por seu intelecto, caráter, posição social, poder econômico e influência na comunidade. Entretanto, se por um lado tornou-se a forma teológica da ideologia liberal, juntamente com o utilitarismo da Revolução Industrial, por outro lado, atraiu milhares de pessoas dos mais baixos extratos sociais, tornando-se refúgio para as frustrações sociais. $\mathrm{O}$ Metodismo não era uma religião somente para a burguesia, mas também para o proletariado. Sua organização e doutrina serviam para os dois propósitos. Para a burguesia servia como estímulo para acúmulo de capital, baseado na máxima do Metodismo: “Ganhai o máximo que puderes, economizai o máximo que puderes, doai o máximo que puderes".

Em 1797 aconteceu oficialmente o primeiro cisma do Metodismo primitivo, por meio de Alexander Kilham, acusado pelos dissidentes de governar de forma arbitrária e injusta. É interessante notar que essas dissidências tenderam a seguir as linhas das classes sociais. Com o enriquecimento das cidades

${ }^{104}$ Citação da The Gentleman's Magazine, abril, 1791, no Volume John Wesley de VHH Green, p. 152. 
industriais, os ricos mudaram para os subúrbios e nas proximidades de suas moradias construíram templos maiores e mais luxuosos. Os templos da cidade, por sua vez, ficaram para os pobres. Esse fato determinou uma ruptura espacial entre ricos e pobres, inclusive entre os metodistas, refletindo o rompimento social da época. ${ }^{105}$

"Embora o metodismo seja em si mais do que o prolongamento da sombra de Wesley, o movimento continua a levar as marcas indeléveis de seu coração e mente". ${ }^{106}$

\title{
3. 5 \\ O Desenvolvimento e as Desigualdades Sociais: o Metodismo nos Estados Unidos da América
}

\begin{abstract}
"Na força do inverno, Chicago apresentava, como todas as grandes cidades do mundo, aos olhos da Cristandade o maior contraste entre ricos e pobres, entre o conforto e o luxo de um lado, e a miséria e a luta desesperada pelo pão, do outro". 107
\end{abstract}

Os Estados Unidos experimentou profundas mudanças desde a segunda metade do século XIX, especialmente após a Guerra de Secessão. Não havia mais quaisquer entraves ao desenvolvimento econômico assentado nos moldes puramente capitalistas. O processo de industrialização ganhava celeridade e o avanço científico confirmava esta prosperidade: telégrafos, ferrovias, telefone, filme de celuloide, rádio e outros; o modelo de organização empresarial inaugura o surgimento da sociedade anônima e a formação de grandes corporações, evidenciando o monopólio das riquezas e do poder. Surgem imensos sistemas de transportes e serviços. Tudo isso indicava que os Estados Unidos emergiam como grande potência imperialista, necessitando promover exportação de capitais excedentes, produtos manufaturados e a importação de matérias primas essenciais.

O progresso da ciência e da técnica, bem como as reformas democráticas e a expansão das indústrias, eram interpretados pelas autoridades religiosas como

\footnotetext{
105 P. Fry. Para inglês ver, 1982, p. 37.

${ }^{106}$ Richard P. Heitzenrater. Wesley e o povo chamado Metodista. EDITEO 1996, p. 319.

${ }^{107}$ SHELDON, C. M. Em seus passos que faria Jesus? Casa Publicadora Batista, 1946, p. 233.
} 
produtos de aperfeiçoamento da civilização cristã e sinais da chegada do Reino de Deus. $^{108}$

Entretanto, este intenso desenvolvimento econômico gerou a progressiva onda imigratória da Alemanha, Inglaterra e Irlanda após 1880, da Europa meridional e oriental, suprindo mão-de-obra não especializadas para as fábricas, minas de engenho e gerando um extraordinário crescimento demográfico.

O processo de urbanização se consolidava aceleradamente. A concentração fundiária e a mecanização agrícola impeliam ainda mais o êxodo rural provocando o inchaço de cidades como Chicago e Detroit. O resultado disso eram cortiços lotados nos bairros mais pobres sem as condições necessárias para sua utilização. Via-se insalubridade, péssima instalações sanitárias e de ventilação.

O local de trabalho também não apresentavam melhorias. As fábricas eram galpões e a jornada de trabalho era de 60 horas semanais. Algumas leis estaduais reduziram a carga horária para 54 horas semanais para o setor têxtil que empregava predominantemente mulheres e crianças. O salário mal supria suas necessidades e nas cidades fabris era trocado por vales ou mantimentos que poderiam ser adquiridos nas próprias companhias.

Resistência aos sindicatos trabalhistas, greves, repressão brutal, exploração e racismo contra os estrangeiros e negros são elementos de acirrados conflitos sociais e raciais, presentes no cotidiano da cidade, desafiando a consciência cristã. Entretanto, herdeiras de uma cultura rural, viam-se completamente despreparadas para lidar com este novo cenário que se configurava. Ancoradas numa tradição individualista eram incapazes de compreender a natureza dos problemas sociais que se apresentavam. Seguiram o velho método da pregação "conversionista", crendo que desta forma obteriam as transformações sociais. Por outro lado, algumas igrejas compostas por camponeses mostravam-se desconfiadas e preconceituosas quanto às pessoas “estranhas" e imorais que se amontoavam nos centros urbanos.

108 Josias Strong, The New Era, 1893, p. 81. 
A maioria das igrejas encontrava-se totalmente imersas na ideologia dominante: O bem-estar coletivo dependia da prosperidade e da poupança individual. Sem ricos não haveria investimentos e sem os pobres não haveria trabalho de baixo custo. Aos seus olhos a igualdade parecia incompatível com o crescimento econômico. Não é de se admirar que o proletariado encarasse a Igreja como complacente indiferença. Para muitos trabalhadores a religião era uma utopia para a vida pós-morte. Outros denunciavam o que supunham ser uma cumplicidade interesseira. Dizia-se: "Se a Igreja não pode cristianizar o comércio, este comercializará a Igreja." 109

E ainda: "Meus associados creem que a Igreja e o ministério são apologistas e defensores do mal praticado contra os interesses do povo, simplesmente porque os perpetradores desse mal são possuidores de riquezas (...) cujo deus verdadeiro é o poderoso dólar. Eles contribuem com um pouquinho dos seus ídolos, para subornarem o intelecto e a eloquência dos teólogos (...)". 110

Entretanto, paulatinamente as Igrejas protestantes foram percebendo a importância da sua presença e ação social junto aos necessitados. Essa mentalidade ganhou força e se expandiu intensamente. Os primeiros articuladores foram da Igreja Congregacional, em seguida, Metodista Episcopal, e Batista.

A Igreja Metodista Episcopal foi a primeira a incorporar a perspectiva do Evangelho Social (Social Gospel) à sua concepção missionária, criando em 1908, em sua Conferência Geral, o primeiro Credo Social que se tem notícia na História da Igreja. ${ }^{111}$

A Igreja não poderia ignorar o sofrimento da população marginalizada e oprimida, muito menos alimentar uma prática assistencialista, destinada mais a tranquilizar a consciência, do que atacar de frente os males que afligiam o pobre.

Não tardou para que tais advertências conseguissem adeptos de todas as denominações. Criaram-se centros educativos e recreativos, utilização de veículos

\footnotetext{
109 RAUSCHENBUSCH Apud Dustan, J. Leslei. Protestantismo, Zahar Editores, Rio de Janeiro, 1964, p. 132.

${ }^{110}$ BUYERS, Paul Eugene, História do Metodismo, São Paulo, Imprensa Metodista, 1945, p. 281.

111 SOUZA, José Carlos, O Metodismo Norte-Americano no Início do Século XX: A Missão como Testemunho Social, Imprensa Metodista, 1991, p. 37.
} 
de comunicação como o jornal para fomentar as discussões sobre problemas sociais forçando importantes alterações na legislação. Departamentos de Ação Social se integraram à estrutura das grandes Igrejas. Cursos de ética social e sociologia foram inseridos nos cursos teológicos. Além disso, não faltaram manifestações proféticas denunciando a injustiça contra trabalhadores, declarações contra a segregação racial, o abandono dos imigrantes, crítica aos monopólios e especulações, manifestos a favor da diminuição da carga horária de trabalho, abolição do trabalho infantil e etc.

\section{6}

\section{A "Era Metodista"}

Na segunda metade da década de 1820 , inicia-se um período que os estudiosos denominam como a "Era Metodista", também chamada de "Era do Homem Comum", que coincide com o primeiro governo de Andrew Jackson que simpatizava com o metodismo. O metodismo estará presente na formação do "homem comum" norte-americano e na educação das classes dirigentes.

O Metodismo desenvolveu-se nos Estados Unidos com características bem peculiares. Wesley enviou alguns de seus melhores pregadores como missionários para a América. Em 1784 os pregadores reunidos, sob a direção de Coke, fundaram a Igreja Metodista Episcopal. Elegeram Asbury (ainda leigo) como Diácono, Presbítero e Superintendente (Bispo). A Igreja Metodista Episcopal iniciou como a menor denominação protestante da América contando somente com 80 pregadores. Posteriormente seria a maior. Isso graças à sua acessibilidade e praticidade, dispensando templos e liturgias sofisticadas. Enquanto os pregadores metodistas convidavam a todos "venham, todos que quiserem", os calvinistas, somente os "eleitos". 112

A ética metodista exerceu grande influência na América, fundamentada em dois postulados: na "fé viva" e nas "obras de justiça". Durante o século XIX,

112 Ducan Reily. História Documental do Protestantismo no Brasil. São Paulo: Aste, 1987, p.102. 
especialmente durante a unificação americana após a Guerra de Secessão, difundiu-se a ideia de que a religião e a civilização estavam unidas na visão da América cristã.

O progresso da tecnologia e da ciência, as reformas democráticas, a expansão da indústria e das obras filantrópicas, eram interpretadas pelas lideranças religiosas como sinais da chegada do Reino de Deus.

"Muitos investigadores têm enfatizado a função da religião civil na criação da auto-imagem do povo americano. Nesse sentido o povo americano se vê como um paralelo ao povo de Deus no Antigo Testamento. Como Deus libertou o povo de Israel da escravidão do Egito, também os puritanos se libertaram das restrições e pressões dos ingleses. "113

No período de "Fronteiras", quando ocorre o fenômeno onde homens e mulheres nas suas caravanas tomando a direção Oeste, conquistando de 30 a 40 $\mathrm{km}$ de terra continental por ano, os pregadores metodistas acompanhavam ou precediam essas caravanas.

Nesse momento, o metodismo vivia um período de "dessacralização do templo", permitindo que pregassem em qualquer lugar: embaixo de uma árvore, numa cabana qualquer, à beira de um riacho, em qualquer lugar onde duas ou três pessoas estivessem reunidas.

Aquelas pessoas, em buscam de uma vida melhor, encontravam lugares espaçosos, dando-lhes a sensação de liberdade. Essa sensação também era inspirada pelo metodismo, à medida que em suas pregações ensinava que todo ser humano é livre para aceitar ou não a graça de Deus. Na busca de uma vida melhor, eles sentem que não estão abandonados ou solitários, mas que Deus se preocupa com eles, alimentando a ideia do progresso fundada na doutrina metodista da santificação e da perfeição cristã.

No momento em que os Estados Unidos se expandem continentalmente, percebem que podem se expandir a nível internacional. Assim procurarão anexar outras terras ao seu território, como, Texas, Alaska, Hawai, Filipinas... Segundo o

${ }^{113}$ Ducam Reily. Metodismo Brasileiro e Wesleyano, 1981, p. 202. 
autor Johnson A. Robson, esse movimento seria somente um "aperitivo para abrir o apetite dos norte-americanos para um banquete ainda muito maior". ${ }^{114}$

Os missionários acreditavam sinceramente que eram portadores de uma mensagem de salvação, no sentido religioso e material: o progresso da civilização americana traria benefícios incontáveis aos povos não cristãos ou não protestantes.

As escolas eram vistas como verdadeiras agências de patriotismo. "As escolas são agências de patriotismo e a Igreja Metodista foi sempre fiel aos Estados Unidos e ao seu símbolo, a bandeira." ${ }^{115}$ O Concílio da Igreja percebe os Estados Unidos como centro da civilização e os metodistas se propõe a comunicar ao mundo seus valores e ideais.

O pastor Mathias S. Kaufman, no jornal oficial da Igreja de Nashville, afirma que: "O imperialismo americano é na sua essência um valor, uma força americana, um sentido americano de justiça, uma resposta à voz de Deus para cristianizar todos os continentes e todas as raças. Este é o espírito cristão de uma República cristã". ${ }^{116}$ Moniz Bandeira, afirma:

"A ideia de um povo eleito por Deus que os puritanos herdam do judaísmo, renasce através de um nacionalismo messiânico, que vê os Estados Unidos como um país chamado por Deus para salvar o mundo". ${ }^{117}$

Essa afirmação é confirmada por um estudioso do protestantismo norteamericano, Clifton Olmstead, que diz:

"A convicção profunda nutrida pelos americanos de que sua nação foi especialmente escolhida para cumprir uma missão universal, foi mantida durante a Guerra Civil". ${ }^{118}$

Na Conferência Geral de 1876, o Bispo Metodista Mattew Simpson, afirmava que: "Os olhos do mundo estão fixos nos americanos e a Igreja

\footnotetext{
${ }^{114}$ Imperialism, a Study, do autor John A. Robson.

115 Journal of the General Conference of the Methodist Episcopal Church. 1900, p. 186.

${ }^{116}$ Journal Chistian Advocate, 14.9.1899, p.9.

${ }^{117}$ Moniz Bandeira. Presença dos Estados Unidos no Brasil. Editora Civilização Brasileira, Rio de Janeiro, 2007.

${ }^{118}$ Clifton, Olmstead, em sua obra, History of Religion in the United States.
} 
Metodista não pode decepcionar as nações". Assim, a Igreja Metodista deveria assumir o papel que lhe fora confiada pelo Senhor, ou seja, ser o oráculo de Deus para anunciar às nações que na América foram criadas as agências visíveis pelas quais o mundo será subjulgado a Cristo: uma nação grande, livre e iluminada, e uma Igreja (Metodista) vivificada pelo espírito missionário do Senhor". ${ }^{119}$

Essa mentalidade será assumida pelos demais bispos. A missão da Igreja Metodista estava identificada com o destino nacional e com o progresso da civilização protestante americana.

"Deus elege nações para cumprir projetos e a nação americana é composta por uma raça de dirigentes destinados a governar o mundo."

No campo da educação, o século XIX representou o tempo de criação e expansão de escolas metodistas nos Estados Unidos. Criavam-se também escolas nas proximidades indígenas para preparar missionários para trabalhar com os nativos.

Quando terminou a Guerra Civil norte americana, em 1865, as mulheres protestantes retornaram dos campos de batalhas para onde tinham ido como enfermeiras e sentem que precisam engajar-se em alguma atividade além de suas rotinas domésticas, em seus lares. Assim, criam associações, sociedades missionárias, organizando ligas antialcoolismo, dentre outros. Posteriormente a educação brasileira constatará esta realidade, pois o movimento missionário centrado na educação do Brasil não foi mantida pela Junta Americana de Homens, ao contrário, foi um movimento liderado pelas mulheres.

Ao final da guerra civil dos Estados Unidos, pode-se constatar que a igreja Metodista é a maior denominação do país e a mais poderosa economicamente. Além disso, possui o maior número de instituições de ensino. Dos seus 200 estabelecimentos de ensino, 34 eram escolas de nível Superior, de onde mais tarde saíram as Universidades: Emory, em Atlanta; Duke University;

\footnotetext{
${ }^{119}$ Declaração do Bispo Simpson no Journal of the General Conference of Methodist Episcopal Church, 1876.

${ }_{120}$ Journal of the General Conference of Methodist Episcopal Church, 1900, p.5.
} 
De Pauw University, Ohio University, dentre outras. Assim, pode-se afirmar que a partir de 1827 o metodismo será a visão dominante dos Estados Unidos. Alguns escritores dirão que o Metodismo e a nação americana andarão "de mãos dadas", apesar da separação entre Igreja e Estado.

Segundo o Dr. Peri Mesquida ${ }^{121}$, esse nexo entre o metodismo e as autoridades políticas norte-americanas pode ser constatado, como retratado a seguir:

a) A Igreja Metodista Episcopal foi a primeira denominação a cumprimentar o Presidente George Washington em 1789;

b) Em reconhecimento ao crescimento e a influência do metodismo sobre a vida e cultura americana, o Presidente Lincoln afirmou em 1864: "A Igreja Metodista pelo seu número de membros é a mais importante denominação americana; não surpreende que ela tenha enviado mais soldados ao campo de batalha, mais enfermeiras aos hospitais e mais orações aos céus que qualquer outra. Deus bendiga a Igreja Metodista."

c) A esposa do Presidente Hayes foi Presidente da Sociedade Missionária da Senhoras de 1881 à 1885. Esta organização era encarregada à realizar trabalhos religiosos para a conversão dos índios, dos imigrantes, bem como trabalhar na formação de mulheres missionárias.

d) Os metodistas, como a maior denominação do país sentiam-se responsabilizados por uma dupla missão:

"... promover o bem-estar geral da nação e de difundir na sociedade os princípios da Escritura Sagrada, únicos capazes de construir o modelo mais elevado de civilização cristã." ${ }^{122}$

Este modelo de civilização cristã é identificado após a guerra civil, onde os ideais, as convicções, as línguas, os hábitos e as instituições norte-americanas estão profundamente ligados aos princípios cristãos a tal ponto, que mesmo a cultura é alimentada pela fé cristã. Mais uma vez pode-se constatar este fato no depoimento de Presidente Roosevelt, quando afirma: "Eu penso que em nenhuma

\footnotetext{
${ }^{121}$ Revista do COGEIME (Conselho Geral das Instituições Metodistas de Ensino). Ano 2, Número 2,1993. p. 37.

${ }^{222}$ Carta Episcopal do Concílio de 1884
} 
parte do mundo a Igreja Metodista desempenhou um papel tão importante e tão especial como nos Estados Unidos. Sua história está indissoluvelmente ligada à história do nosso país" ${ }^{123}$.

A Igreja Metodista, enquanto Igreja dominante estava estritamente ligada a esta concepção de responsabilidade do destino da nação. Os metodistas eram unânimes de que seu país representava o "último esforço de Deus para salvar a raça humana". ${ }^{124}$

Nesse contexto ideológico, cultural, político e teológico, a expressão de John Wesley "O mundo é minha paróquia" passa a ser internalizada na consciência dos metodistas norte-americanos onde o mundo é uma "paróquia" dos Estados Unidos!

Os Bispos tinham tão grande influência sobre os Presidentes do país, que chega-se a dizer: "Quando os Bispos e os pregadores falam, os homens políticos escutam com a mesma atenção que os seus fiéis". ${ }^{125}$

Para os metodistas norte-americanos, o desenvolvimento econômico do seu país após a Guerra Civil, era reflexo da vontade de Deus, pois "o mesmo Deus que conduziu Israel, guia, hoje, os Estados Unidos, e os princípios que serviam de fundamento para o povo hebreu regem o nosso país agora". ${ }^{126}$

De 1820 a 1840, a Igreja Metodista americana criou diversos seminários teológicos, que cresceram e se fortaleceram transformando-se em escolas superiores.

Em 1808 a Igreja Metodista Episcopal rompeu-se em duas. Em 1844 consolida-se a divisão do Metodismo nos Estados Unidos. O principal tema para esta cisão foi o da escravidão: Igreja do Norte (que defendia a libertação dos escravos) e a Igreja do Sul (que era a favor da escravidão).

\footnotetext{
123 Revista do COGEIME. Metodismo e Educação no Brasil: Formar Elites e Civilizar a Nação. Ano 2, Número 2, 1993. p. 37

${ }^{124}$ Methodist Publishing House, Methodist Review . VI. 72, 1890, p. 863.

${ }^{125}$ Revista do COGEIME. Op. cit., p. 38.

${ }^{126}$ Methodist Publishing House, Methodist Review, J. W. Mendenhall, VI. 75, 1893, p. 459.
} 


\title{
4
}

\section{A Educação Metodista e seus Modelos Pastorais no Brasil}

\author{
Canção do Exílio - Gonçalves Dias, 1843 \\ "Minha terra tem palmeiras, \\ Onde canta o Sabiá; \\ As aves que aqui gorjeiam, \\ Não gorjeiam como lá. \\ Nosso céu tem mais estrelas, \\ Nossas várzeas têm mais flores, \\ Nossos bosques têm mais vida, \\ Nossa vida mais amores. \\ Em cismar, sozinho, à noite, \\ Mais prazer encontro eu lá; \\ Minha terra tem palmeiras, \\ Onde canta o Sabiá.
}

\begin{abstract}
Não permita Deus que eu morra, Sem que eu volte para lá; Sem que desfrute os primores Que não encontro por cá;

Sem que ainda aviste as palmeiras,

Onde canta o Sabiá."

Não permita Deus que eu morra,

Sem que eu volte para lá;

Sem que desfrute os primores

Que não encontro por cá; Sem que ainda aviste as palmeiras, Onde canta o Sabiá."
\end{abstract}

\section{1}

\section{Um panorama do Brasil Colônia}

O metodismo já estabelecido no Novo Mundo crescia e se consolidava a cada dia numa visão expansionista não só dentro de seu território, mas também 
em outras nações. Dentre as demais, havia a intenção de chegar ao solo brasileiro. Entretanto é importante verificar como vivia o Brasil neste período, esse país de grandeza continental: suas principais características políticas, religiosas e econômicas, antes da chegada do metodismo em suas terras.

É bom relembrar que a nação portuguesa, no período de colonização do Brasil, assumia uma forma de colonização: cria em sua "vocação divina e messiânica" que é a propagação da fé cristã e a eliminação dos "inimigos do cristianismo". Assim, as guerras assumem um papel religioso: conquistar o mundo em nome da fé. A figura do monarca português se reveste de sacralidade, vinculada ao Romano Pontífice (representante de Deus na terra, conforme as teorias medievais de cristandade). Ao longo dos séculos XV e XVI, Portugal se transformará em uma potência comercial, um imponente império, aliado ao ideal religioso: "Dilatar a fé e o império" - a Igreja e o Estado, unificados na pessoa "sagrada do rei".

Tem-se o registro da presença de franciscanos, que acompanharam a frota cabralina de 1500. Mais tarde tem-se a presença dos jesuítas, inacianos, com a finalidade missionária de restabelecer os bons costumes e a conversão dos gentios, para entrarem na "ordem da graça", da qual a Igreja é portadora. Assim na visão colonizadora, primeiramente deveria se dominar o índio, como forma de proteção e depois convertê-lo, estabelecendo o chamado padroado, ou seja, a construção de uma sociedade integralmente cristã. Nesse projeto religiosopolítico, o poder civil e o eclesiástico trabalharam juntos, tendo seu ponto de convergência no monarca. O monarca é investido de "poderes pontifícios" para administrar seus respectivos territórios e a instituição eclesiástica, promovendo e sustentando as "obras religiosas", ou seja, a propagação da fé cristã e consolidação da Igreja. Desta forma criava-se total dependência da Coroa. Todos os eclesiásticos submetiam-se oficialmente à autoridade "sagrada" do rei. Os assuntos referentes à Igreja eram tratados no departamento administrativo civil, chamado: Mesa de Consciências e Ordens. Desta forma, o padroado esvaziou-se do seu significado religioso. Muitas iniciativas pastorais foram asfixiadas, e o entusiasmo pela religião, aferrecido. Reduziu-se a criatividade dos obreiros no 
campo missionário, enfim, esse quadro contribuiu com o surgimento de uma mentalidade de conformismo e acomodação entre os clérigos e os fiéis.

O Padroado no Brasil poderia ter trazido mais benefícios à Igreja e sua missão evangelizadora. Porém o poder da Coroa e da Igreja tiveram muitos momentos de tensões. O aspecto profético do anúncio e denúncia da verdade evangélica, neste modelo, foi retirado.

A força missionária predominante na Colônia era a evangelização dos índios por meio dos jesuítas. Os jesuítas foram criados por Loyola. Constituía-se em uma congregação voltada para a propagação da fé católica romana. Procuravam ajudar na salvação e perfeição dos povos. Em 1540, o Papa Paulo III aprovou o Instituto Inaciano. No mesmo século difundiram o catolicismo na China, no Japão, no Congo, Angola e no Brasil em 1549, num esforço acima de tudo na doutrinação das crianças fazendo-os "índios cristãos". Adaptaram o catolicismo à cultura local (Tupi), montando uma gramática e tornando a leitura religiosa uma obrigação. Por mais que estivessem associados aos reis católicos, o soberano da Companhia era o papa. Os Colégios Inacianos se espalharam por todos os continentes, formando professores, intelectuais e missionários.

O método de ensino estava baseado e inspirado na pedagogia jesuítica, herança centrada no Ratio Studiorum (promulgado na Contra-Reforma, na Europa, 1599). Este documento organizava a aprendizagem em três princípios básicos: a unidade da matéria, o método e o professor. Nele o ensino clássico centrava-se na transmissão do conhecimento através da memorização orientada pelo mesmo professor por muitos anos, caracterizando-o como mestre.

Em 1549 chegam os primeiros inacianos. A missão era de conduzir os índios à fé católica e torná-los obedientes ao rei. Se de um lado havia as genuínas intenções evangelizadoras, de outro, as estruturas coloniais capitalistas e opressoras dificultavam a ação missionária mais livre e eficaz. Na mentalidade da época, o que importava era erradicar o núcleo religioso dos mitos indígenas considerado como expressão diabólica. Assim, convencido que uma ação evangelizadora eficaz e duradoura exigia a concentração geográfica dos índios, em 1552 o padre Nóbrega iniciou os aldeamentos missionários onde os índios 
deveriam "se habituar ao trabalho" e se "sujeitar às disciplinas". Eles deveriam ser instruídos na religião católica e nos bons costumes. Num primeiro momento parecia que a obra evangelizadora havia sido exitosa, com muitos batismos e crismas, entretanto, entre 1628 e 1630, os colonizadores, depois de muita crueldade, apresaram mais de 60.000 índios das Reduções do Paraguai e Uruguai, levando-os para São Paulo e Rio de Janeiro. Outros episódios semelhantes ocorreram. Muitos índios morriam "estranhando a terra", sem conseguir adaptarse à nova situação.

Quanto à obra educadora, os jesuítas foram os primeiros educadores no Brasil, estabelecendo colégios, onde estudavam: órfãos trazidos de Lisboa, filhos de índios e mamelucos que sabiam a língua da terra, preparando-os para a catequese. Porém, o objetivo primeiro era atender os filhos dos colonos brancos e também servia como preparação de candidatos ao ministério presbiteral. Alguns colégios eram financiados pela Coroa e também prestavam serviços sociais à população, como as enfermarias e suas farmácias (já naquele tempo manipulavam-se as plantas medicinais).

Destacam-se alguns jesuítas que com qualidades pessoais marcaram a história da Igreja Católica no Brasil, entre eles, padre José de Anchieta, que se dedicou ao estudo da língua tupi e à catequese dos indígenas. Juntamente com padre Nóbrega empreendeu missão pacificadora entre os tamoios. Manteve grande esforço de aproximação e convivência com os indígenas, marcado por seu "ardor apostólico e caridade compassiva".

Os jesuítas entre 1749-1759 se espalharam pelo território brasileiro. As missões volantes eram centralizadas nos colégios da Bahia e do Rio de Janeiro. Desde 1556, foram fundadas Casas onde era oferecido ensino elementar da catequese entre indígenas. Essas Casas originaram residências, missões, colégios, igrejas e seminários.

Entre os fundadores da Companhia, está Francisco Xavier, que em 1541, partiu para o oriente, para o meio dos gentios. Trabalhou no sul da Índia, Molucas e Japão. A ele, deve-se a redefinição do modelo missionário da Igreja Católica, reconhecendo a necessidade de enviar clérigos, devidamente treinados a todas as 
partes do mundo. Assim como ele, Nóbrega foi inovador no modelo de comunicar a religião cristã aos gentios, utilizando inclusive, melodias tupis para canções com letras cristãs (o que foi repudiado por muitos católicos). Mais do que divulgar o evangelho, os jesuítas foram da Amazônia à China, precursores do diálogo entre culturas: fundaram cidades, escreveram dicionários e preciosos relatos sobre hábitos e línguas locais.

Os serviços prestados pelos jesuítas à Igreja de Roma transformaram a Companhia em uma potência econômica. Entretanto, em 1759, os jesuítas foram expulsos de Portugal e de suas colônias, tendo os seus bens confiscados. Posteriormente outras monarquias seguiram o exemplo luso. Muitos foram presos e vários ingressaram em outras ordens. Somente em 1814, a Companhia foi restaurada.

\section{2}

\section{Resistências para a chegada do Protestantismo no Brasil}

Durante vários séculos a terra descoberta por Cabral esteve proibida de receber influência do protestantismo, assim como do judaísmo e islamismo. A coroa portuguesa sentiu-se na obrigação de preservá-la distante de quaisquer ideologias consideradas perniciosas às suas crenças e interesses religiosos, políticos e econômicos. No caso dos estrangeiros, o arrocho foi incomparavelmente rigoroso. O cientista alemão Alexandre von Humboldt sofreu o vexatório impedimento de entrar no Brasil, pois temiam que contagiasse o povo com suas supostas ideias nefastas. O mesmo afirmou que o Brasil era um "jardim amuralhado". Não apenas isso: A atuação do Santo Ofício perdurou por pelo menos três séculos: Inaugurada em 1536 com comissários nos grandes logradouros, incumbidos de receber denúncias, prender os acusados e remetê-los à Inquisição sediada em Lisboa. Manteve-se até a Independência do Brasil, em 1822. O referido Tribunal costumava enviar membros do seu corpo para inspecionar, ouvindo, em audiência sigilosa tudo quanto se referisse aos costumes, 
à moral e à ortodoxia da Igreja, mandando em seguida encarcerar os réus, despachando-os para a Metrópole, devidamente processados. De igual modo, cuidava para expurgar do país qualquer literatura estranha às normas estabelecidas no Concílio de Trento (1545- 1563). Assim, é bom que se ressalte que o ingresso da Bíblia de tradução protestante se deu muitas vezes de forma clandestina. Nesse contexto, o protestantismo nunca poderia firmar os pés no meio das populações brasileiras.

Por uma série de fatores de natureza intelectual e política pela qual o mundo atravessava, o continente europeu sofreu profundas mudanças nas suas estruturas durante as últimas décadas do setecentismo. A França encarnou o sentimento e efervescência da época, tornando-se cenário de violenta revolução. O que se pretendia era: a substituição das monarquias absolutistas por regimes democráticos, o enfraquecimento da aristocracia, a melhoria das condições de vida das classes inferiores, a abolição de determinados privilégios e a garantia dos direitos naturais do ser humano.

Por fim, Napoleão Bonaparte assume as rédeas do governo francês, assumindo guerra entre diversas nações, inclusive a Inglaterra, aliada de Portugal. Assim, a Corte lusitana precisou transpor o Atlântico e vir asilar-se no Brasil. Enquanto isso, os soldados ingleses defendiam o território ibérico.

Assim que a família real desembarcou em Salvador, na Bahia, o então Príncipe Regente, futuro D. João VI subscreveu um importantíssimo decreto no qual abria os portos às nações amigas, fortalecendo, inclusive o intercâmbio e amizade com a pátria de John Wesley, a Inglaterra. Em consequência, além dos cônsules, o país recebeu um crescente número de negociantes, sobretudo no Rio de Janeiro, Bahia e Pernambuco. Receberam-se, também os primeiros imigrantes suíços e alemães (muitos dos quais pertenciam a alguma origem evangélica).

O governo precisaria oferecer-lhes condições favoráveis. Os ingleses começaram a exigi-la, como: o direito de praticar a religião de origem (mesmo que em recinto privado); e ter capelão e construir edifícios para o culto divino. Mesmo com oposição da Igreja Católica, D. João contornou as tensões e no Tratado de 1810, no Artigo XII, removeu o dilema contentando ambos os lados. O 
Tratado de Livre Comércio de 1810 - entre outras coisas, também instituiu a liberdade de culto aos dissidentes religiosos, os protestantes, o que facilitou a permanência e consolidação da missão evangélica. Neste mesmo ano os súditos ingleses realizaram os ofícios divinos na residência do ministro plenipotenciário britânico, Lord Strangford. Entretanto, os protestantes não poderiam fazer prosélitos.

Em 1816, negociantes estrangeiros e capitães de navios receberam exemplares da Bíblia e do Novo Testamento em português, para distribuição a toda gente. Em 1818 chegaram os imigrantes suíços e alemães. Em agosto de 1819 os anglicanos inauguraram o seu templo à Rua dos Barbonos, sendo o primeiro templo em toda a América do Sul. Em 1827 os luteranos, que já se reuniam em congregações esparsas, inauguraram o culto em uma sala alugada e em 1845 inauguraram o templo. O casamento, porém, só era válido se efetuado por sacerdote católico romano. À medida que os anos se passavam outras medidas que favoreceriam os protestantes foram promulgadas, dadas às necessidades e circunstâncias.

A Constituição de D. Pedro I, datada de 1824, confirmou a ampliação de algumas vantagens para os não-católicos romanos, entre eles os protestantes. Foise instituído que os acatólicos poderiam ser eleitores, porém inelegíveis para os altos cargos da Nação. Art. 95. "Todos os que podem ser eleitos, hábeis para serem nomeados Deputados, excetuam-se:

I. Os que não tiverem quatrocentos mil réis de renda líquida, na forma dos Arts. 92 e 94.

II. Os Estrangeiros naturalizados.

III. Os que não professarem a Religião do Estado."

O Artigo 5 é sintomático nesse sentido, pois estabelecia a liberdade de culto. "A Religião Catholica Apostolica Romana continuará a ser a Religião do Império. Todas as outras Religiões serão permitidas com seu culto doméstico, ou particular em casas para isso destinadas, sem forma alguma exterior do Templo."

O espírito liberal se acentuava mais e mais no seio das classes pensantes. Homens do porte do Senador Vergueiro e do Padre Freijó esforçaram-se para atenuar o rigor das leis, introduzindo mudanças nas mesmas. Em 1829 o Senador 
Vergueiro, e em 1833 o Padre Freijó pugnaram a favor do casamento civil. Freijó chegou a encaminhar um projeto com vista ao casamento dos sacerdotes. $\mathrm{Na}$ verdade havia outros cleros com pensamentos liberais graças ao influxo de ideias colhidas em Coimbra, onde estiveram à estudos. Destaca-se, ainda, a grande contribuição da imprensa desta época em diante. A literatura francesa desfrutava de boa aceitação, trazendo influências multivariadas. Segundo Salvador,

"Os jornais que aqui expunham os pensamentos liberais, possuíam vida curta, ao contrário dos conservadores. Entretanto, essa situação se alterou à medida que se desenvolviam o abolicionismo e o republicanismo. Destacam-se: $\mathrm{O}$ Diário de Pernambuco, Correio Paulistano, a República (Rio de Janeiro), a Gazeta de Notícias, a Província de São Paulo, entre outros". 127

A inserção do protestantismo no Brasil seria quase impossível, não fosse o cenário histórico que apontava para a Questão Religiosa: Por um lado as ideias liberais que chegavam como resultado do Iluminismo, a busca do progresso para sair da estagnação colonial e o exemplo de extraordinário desenvolvimento das nações protestantes. Tudo isso contribuiu para gerar no Brasil, no início do século XIX uma mentalidade favorável para a inserção e consolidação do protestantismo no Brasil. Por outro lado a relação de tensão entre o Estado liberal e a Igreja Católica Romana antiliberal gerava intensos conflitos. Este cenário, desenvolvido desde o Concílio Vaticano I, abriu espaço ideológico para a penetração e aceitação do protestantismo.

Este era o quadro quando os metodistas dos Estados Unidos da América iniciaram um trabalho nas terras do Cruzeiro do Sul. Permaneceram de 1836 até 1841, quando precisaram interromper o trabalho desenvolvido aqui para regressar à Pátria, só retornando a atenção para o Brasil ao término da guerra civil em seu país, ou seja, no governo do Imperador Pedro II (1868).

Chegaram ao Brasil: Anglicanos, Episcopais, Metodistas, Luteranos, Reformados Holandeses, Puritanos (Presbiterianos e Congregacionais), Quacres e Batistas.

${ }^{127}$ José Gonçalves SALVADOR, em História do Metodismo no Brasil. 
Inicialmente o número de Pietistas era pequeno, e aumentou enormemente com a chegada dos Metodistas. A essa altura, o Protestantismo se configurava bem distinto de seu perfil europeu. Cada grupo havia absorvido um pouco do outro.

Especialistas como Ducan A. Reily e Antônio G. Mendonça afirmam que as diversas denominações protestantes que se estabeleceram no Brasil eram frutos da "Era metodista" - a ênfase principal era ao apelo individual e à conversão. Os autores também ressaltam a criação de escolas que difundiam a "cultura protestante" com métodos educacionais modernos, atraindo grande parte da elite da sociedade, que mesmo sem a aparente "conversão", estaria sendo influenciada por valores e princípios cristãos. Finalmente as escolas também faziam o trabalho de visitar as famílias dos alunos, compartilhando literatura evangélica. Muitos alunos e familiares tornaram-se protestantes.

Quanto à conversão e disciplina, as igrejas protestantes surgidas do movimento missionário do séc. XIX identificam "conversão ao evangelho" com a rejeição de uma cultura e do mesmo modo, à adoção de outros padrões culturais, com os quais elas associam formas de comportamentos regidos por uma disciplina rígida e enérgica da congregação local à luz da sua compreensão das Sagradas Escrituras.

De um modo geral, cria-se que a verdadeira conversão deve estar voltada para Deus e seus propósitos, refletindo a gratuidade do perdão e da Graça se manifestando no amor ao próximo. Segundo Mendonça, ainda hoje será necessário um reencontro com a cultura e uma renovação teológica, missiológica, litúrgica, hinológica, comportamental e ecumênica de alguns setores do protestantismo brasileiro.

O protestantismo missionário brasileiro não veio do continente europeu, mas dos Estados Unidos, cujas raízes eram da Reforma inglesa. Pretendia ser elemento transformador da sociedade, através da transformação do indivíduo. Émile-G. Léonard, um dos primeiros historiadores do protestantismo brasileiro, comparando o protestantismo brasileiro do europeu, afirmou "este trabalha, enquanto o outro adora". Por isso não cabe comparação entre ambos. A finalidade 
da religião é distinta. A seguir o historiador destaca os ramos do protestantismo no Brasil - de origem missionária, migratória e os pentecostais:

1. Anglicanos, Episcopais e Metodistas

2. Luteranos (ligados à Alemanha, aos Estados Unidos, e do Brasil)

3. Reformados - Presbiterianos, Congregacionais, Reformados Europeus

4. Pentecostais Clássicos (Assembleia de Deus, Congregação Cristã no Brasil, Evangelho Quadrangular, Brasil para Cristo) e Pentecostais de Cura Divina (Deus é Amor, e numerosas outras). Vê-se a progressão do expansionismo anglo-saxão e protestante no mundo latino e católico. Esse rompimento se consolida no séc. XIX na esfera política e econômica, mas não quanto à religião e à cultura já implantada.

O protestantismo histórico teria todos os motivos para se extinguir, mas resistiu até aqui. $\mathrm{O}$ autor ressalta três possíveis fatores: forte apelo à piedade individual e independência pessoal quanto à salvação; ênfase na participação do leigo; hegemonia econômico-política.

Protestantismo de Origem Missionária - Na virada do séc. XIX, a expansão colonial do mundo anglo-saxão elevou o movimento missionário à escala mundial. Em 1910 a Conferência de Edimburgo criou o "Corpo Cristão Mundial" para centralizar iniciativas de missões entre os povos considerados pagãos, como asiáticos e africanos. Entretanto esta conferência chocou-se com a ideia desenvolvida ao longo do século XIX que considerava os povos católicos como pagãos, pois, segundo Cotton Mather $^{128}$, o catolicismo implantara na América Latina um cristianismo deformado. Portanto, a América Latina, inteiramente católica, tinha, para os conservadores, de estar dentro dos objetivos missionários.

A vertente dominante nas missões protestantes era de Jonh Wesley: a fé era determinada pela experiência pessoal, rompendo com seu meio cultural, adotando novos padrões cristãos de conduta.

\footnotetext{
${ }^{128}$ Cotton Mather (Boston, 12 de fevereiro de $1663-13$ de fevereiro de 1728 ) foi um ministro protestante puritano de grande influência social e política na Nova Inglaterra (nordeste dos Estados Unidos).
} 
Quanto à cronologia das Igrejas de Missões, no Brasil, segue-se deste modo:

1836 - Igreja Metodista e posteriormente em 1886;

1855 - Igreja Congregacional;

1870 - Igreja Presbiteriana;

1881 - Igreja Batista;

1898 - Igreja Episcopal.

Pentecostalismo no Brasil:

1910-1911 - Igreja Assembleia de Deus e Congregação Cristã no Brasil;

1950 - até início da década de 70 - Igrejas Pentecostais;

1956 - Brasil para Cristo e Agências de Cura Divina;

Organizações paraeclesiais.

Para o historiador K. S. Lautorette, o período de 1815-1914, constitui o grande século do cristianismo, especialmente para o protestantismo. Foi o período de formação de sua teologia e sua difusão. Ao mesmo tempo em que no interior dos grandes avivamentos formava-se a teologia prática do conversionismo, no subterrâneo do Iluminismo, gestava-se a teologia liberal que iria, no século XX, minar as próprias bases das missões.

Segundo o autor, há duas causas para as perdas e crises do protestantismo missionário desde 1914 para cá: a teologia liberal (cujo principal componente foi a crítica histórica) e a revitalização das nações não-cristãs (Japão, China, países árabes,...). Segundo Carl Joseph Hahn, a fé cristã foi sendo reduzida a uma questão de consciência e não de revelação. Assim a teologia liberal minou a inspiração da Bíblia e a Cristologia. Neste cenário surgem as organizações Paraeclesiais após a II Guerra Mundial. Elas estão ligadas às Juntas e Comitês das Igrejas Norte-americanas, com organização e sustento independentes delas. Atuam em três diferentes níveis: Evangelização de massa, como a Visão Mundial que mobiliza as denominações para grandes eventos; Acampamento para a 
Juventude (como o Palavra Viva - objetivo conversionita) e Literatura (Editora Betânia e Vida Nova são alguns exemplos).

\section{3}

\section{A Chegada dos Missionários Metodistas no Brasil}

O historiador J. L. Kennedy, em sua obra, Cincoenta anos de Metodismo no Brasil, escreveu que em 1832 a Conferência Geral da Igreja Metodista "considerou a possibilidade de abrir trabalho missionário na América do Sul". O historiador Buyers, em sua obra "História do Metodismo", relata:

(...) Depois de conquistarem independência de Portugal e Espanha, havia um espírito mais liberal e tolerante. Por isso mesmo era propício para neles se propagar uma forma mais pura do Cristianismo. Sentiram, pois, a obrigação de introduzir as suas instituições neste país."

A Sociedade de Missões pediu aos bispos que nomeassem alguém para fazer a viagem de investigação na América do Sul, visitando o Rio de Janeiro e Buenos Aires. Em 1834 houve uma "chamada de missionários para a América do Sul e o Rev. Fountain E. Pitts ofereceu-se como voluntário para esse importante trabalho", sendo nomeado pelo bispo James Andrews, de Tennessee. Após levantar fundos para sua empreitada missionária, saiu de Baltimore em 28 de junho, chegando ao Brasil em 19 de agosto, na cidade do Rio de Janeiro. O missionário, Rev, Pitts trouxe uma carta de apresentação assinada pelo Presidente dos Estados Unidos, Andrew Jackson e pelo Presidente do Congresso americano, William Clay. A Igreja Metodista iniciou seu trabalho no Brasil em 1835, sendo portanto, pioneira na obra missionária protestante nesta terra. Embora sua tarefa primeira fosse de sondagem, nos quinze dias que esteve aqui, logo iniciou seu trabalho ministerial, pregando em 8 casas de ingleses e norte-americanos. Organizou uma sociedade metodista para aqueles que queriam "fugir da ira vindoura". Em seguida, partiu para Montevidéu e Buenos Aires. Ele permaneceu por quase seis meses na América Latina. 
Em 1836 retornou à sua pátria e apresentou seus relatórios otimistas quanto à viabilidade de implantar a Igreja Metodista no Brasil.

"O pequeno grupo de metodistas precisará muito de um cristão experimentado para conduzi-lo e espero que o mesmo seja primícia de uma safra gloriosa."

Ele também oferece algumas características necessárias deste obreiro:

"...um homem de vivo zelo, da paciência de Jó e de verdadeira filosofia cristã. Um pregador que coloque todos os seus cuidados no Senhor Jesus, e que pregue com o Espírito Santo mandado do céu".

Alerta, ainda:

" se for enviado um malabarista metafísico, com a compreensão artificial da santidade do coração, seu trabalho será tão inócuo como um frio raio de lua sobra uma montanha de gelo."

Em março de 1836 o Rev. R. Justin Spaulding foi enviado para o Rio de Janeiro e logo organizou entre os estrangeiros uma congregação com cerca de 40 pessoas. Em junho do mesmo ano abriu-se uma Escola Dominical com 30 alunos, dos quais alguns eram brasileiros, ensinados na sua própria língua, além de ter iniciado um projeto anexo, que era a Biblioteca da Juventude.

Com menos de um mês no país alguns amigos recomendaram e rogaram que abrissem uma escola metodista, alegando que faltava na cidade uma escola de qualidade. Encaminhou-se sua justificativa para a Sociedade Missionária:

"A implantação de escolas com princípios liberais será um dos meios mais eficientes para alcançar a população e que muitas famílias que valorizam a educação enviam seus filhos para outros países. O objetivo religioso permanecerá central no projeto educacional. Se pudéssemos prestar-lhes esse serviço, creio que com a bênção de Deus, talvez pudéssemos nos aproximar deles para prestar-lhes um serviço maior, sim, o maior dos serviços, o de encaminhá-los ao "Cordeiro de Deus que tira o pecado do mundo." 129

Entretanto, o trabalho exigia mais obreiros. O pedido foi atendido e em novembro de 1837 o Rev. Daniel P. Kidder e sua esposa Da. Cynthia Harriet

${ }^{129}$ Christian Advocate and Journal. New York in Salvar e Educar, José Carlos Barbosa, p. 15. 
Kidder, na qualidade de professora e Mr. R. M. Murdy viajaram do Texas para o Rio de Janeiro, a fim de corroborar com o trabalho já realizado pelo Rev. Spaulding. Entretanto alguns fatores levaram a Igreja americana a fechar essa missão, como pode se averiguar a seguir:

1. A esposa do Rev. Kidder, Da. Cynthia Harriet Kidder faleceu, vítima da febre amarela, deixando-o com dois filhos pequeninos, um com apenas alguns meses de vida, e por isso entre 1839-1840 ele retorna a seu país.

2. Um casal de professores trazidos por Kidder casa-se e retorna ao país de origem.

3. A Igreja Metodista norte-americana atravessava momentos delicados e tensos com discussões sobre a escravidão, o que resultou na divisão em Igreja Metodista do Norte e do Sul, em 1844. Assim as missões precisariam ser replanejadas.

A primeira missão metodista no Brasil se extingue, retornando somente após o fim da Guerra Civil, nos Estados Unidos. Permanece, entretanto o testemunho destes obreiros:

"Parece que a propaganda dos Srs. Spaulding e Kidder foi bastante enérgica, não só pela pregação verbal, como pelo derramamento de Bíblias, Testamentos e Tratados ou opúsculos religiosos (...)

Esse período de 6 anos de atividade foi muito promissor para o início de uma obra assim, importante. Foi pena que teve que sofrer uma interrupção de 25 anos, mas mesmo assim, os frutos colhidos foram de grande importância para o Reino de Deus, (...)"

Após esse período de interrupção, em 1867 o Rev. J.E. Newman chega ao Brasil para recomeçar o trabalho. Em carta dirigida aos metodistas de sua terra natal, ele elogia o Brasil:

"Agradecerão a Deus por esta linda e favorecida terra de refúgio... pois aqui acharão liberdade para adorar a Deus... aqui também erguerão firmemente a bandeira do nosso cristianismo protestante e cantarão os doces cânticos de Sião, como antes, na sua terra natal. E ainda que a linda mangueira, com seus largos ramos e agradável sombra seja, temporariamente, sua única casa de oração, mesmo assim se reunirão para adorar a Deus, e os hinos de Watts e Wesley serão cantados no Brasil, como em outras terras. ${ }^{130}$

\footnotetext{
${ }^{130}$ New Orleans Christian Advocate, New Orleans, 23-10-1867, p. 1 in Salvar e Educar, José Carlos Barbosa.
} 
O Rev. Newman continua insistindo que novos obreiros sejam enviados e expressando seu otimismo quanto ao trabalho missionário realizado. Em 1871 ele escreve:

"Muitos brasileiros estão prontos para o Evangelho e dariam boas-vindas a sua introdução no país. (...) Chegou o momento de pregar o Evangelho a este povo. Os cristão americanos devem saber que uma grande seara está esperando trabalhadores! Aos jovens que estão se incorporando ao ministério, eu faço um apelo especial: aqui, meus irmãos, está o campo para o seu trabalho. Venham a esta bonita terra, a este amável povo.Venham pregar Cristo para eles... ${ }^{13}$

Em 1876, pode-se conferir nova carta, quase cinco anos mais tarde, com o mesmo clamor missionário:

"Este grande império está aberto ao evangelho... O império está totalmente aberto à educação, e são largas as portas abertas ao protestantismo... Esta é a segunda maior nação do nosso continente, com um governo estável está com as portas abertas e os intelectuais da nação estão nos convidando para ocupar o campo... Pedimos mais dois missionários. Pedimos apenas dois porque não acreditamos que vocês possam levantar fundos para mais obreiros. (...) Espero de nossa Igreja um esforço especial no sentido de dar o evangelho ao Brasil. $(\ldots)^{132}$

4. 4

\section{O Projeto Liberal Republicano e o Metodismo}

Os metodistas chegaram ao Brasil com ideias e princípios do liberalismo francês e americano: liberdade, igualdade e fraternidade. Entretanto é bom ressaltar que as ideias liberais foram absorvidas e assimiladas pela classe intelectual do Brasil. As massas analfabetas e incultas não deram o apoio e adesão necessários.

O nacionalismo (traço marcante do liberalismo europeu) não tinha a mesma significação no Brasil. A economia basicamente de exportação dificultava maior comunicação entre as regiões brasileiras e, por conseguinte, o fortalecimento necessário dessa bandeira. O modelo de dependência econômica

\footnotetext{
${ }^{131}$ Christian Advocate and Journal. New York in p. 24.

${ }^{132}$ Anual Report the Brazil Mission Conference of the Methodist Episcopal Church, 1876-1901, in Salvar e Educar, José Carlos Barbosa, p. 25.
} 
também gerou dependência cultural, inclusive no modo organizacional da educação. Exemplo disso vê-se o movimento denominado "Entusiasmo pela Educação", buscando sua fundamentação em Pestalozzi e outros teóricos.

É dentro deste contexto (no final do Império e início da República) que implanta-se o Metodismo no Brasil. O império brasileiro buscava modelos culturais, padrões de comportamento e ideias na Europa (especialmente na França). O que havia era a cultura indígena e africana, desconsideradas e desprezadas pela elite, além de não comportarem o modelo mercantilista tão almejado. Esse "transplante cultural" também será consolidado na educação, particularmente na confessional protestante. Toda a campanha republicana teve como referência a nação dos Estados Unidos. A própria Constituição Republicana foi copiada da Constituição americana, com algumas adaptações. O Presidente da Constituinte, Prudente Moraes, ao outorgar a Constituição ao povo brasileiro, declara: "Temos, agora, um conjunto de leis baseado na Constituição mais perfeita do mundo, a Constituição dos Estados Unidos". Até a bandeira republicana era semelhante à bandeira americana: listras verdes e amarelas com estrelas. Isso retrata a nova concepção de mundo na formação de uma mentalidade e modo de produção que estavam presentes, não podendo mais estar em acordo com a monarquia, com a escravidão, com os grandes latifúndios, e com a união entre Igreja e o Estado.

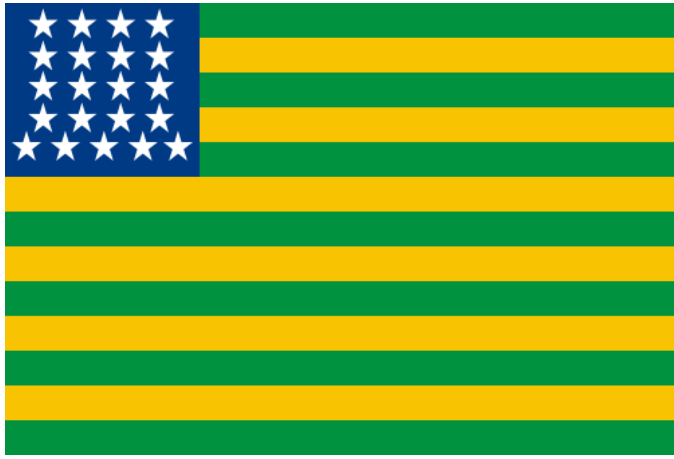

FIG 10 - Bandeira do Brasil no início da República

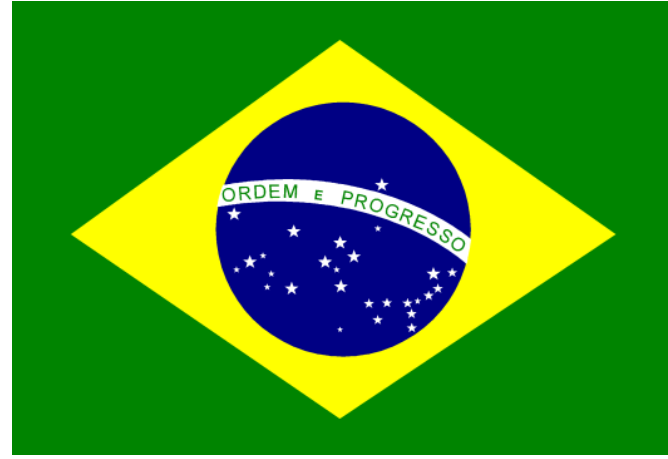

FIG 11- Bandeira do Brasil atual

Com a implantação do regime republicano e com o avanço das relações industriais no país, novos fatores surgiam intensificando as preocupações educacionais, dessa vez, com a adesão da sociedade a fim de sustentar e legitimar 
as novas instituições econômicas e sociais. Entretanto, as escassas atividades econômicas nacionais, as exigências da dominação capitalista e a concentração de privilégios, sobressaíam às “ilusões de ascensão ocupacional via ascensão escolar". Segundo Novaes,

"A pregação liberal impulsionou e avalizou um rearranjo politico organizado em favor da fração hegemônica da classe dominante e das elites que a representavam, mas teve como consequência imediata o ressurgimento das propostas de adequação do sistema educacional à nova ordem democrática (...)".

O regime republicano implantado nada favorecia nas mudanças qualitativas na educação. Isso, em parte, justifica o sucesso e a incorporação dos pressupostos educacionais liberais na crença das camadas subalternas, inquietas e ignorantes das verdadeiras causas da miséria. Assim, expandir as oportunidades educacionais ou reformar as instituições educacionais representava um custo menor do que alterar a distribuição de renda e as relações de poder. Surge o movimento da Escola Nova. A Escola nova, também chamada de Escola Ativa ou Escola Progressiva, foi um movimento de renovação do ensino, que surgiu no fim do século XIX e ganhou força na primeira metade do século XX. Nas palavras de J. Dewey a solução seria:

“... criar nas escolas uma projeção do tipo de sociedade que desejaríamos realizar; e formando os espíritos de acordo com esse tipo, modificar gradualmente os principais e mais recalcitrantes aspectos da sociedade adulta." 133

Na essência da ampliação do pensamento liberal no Brasil, propagou-se o ideário escolanovista. No escolanovismo acredita-se que a educação é o exclusivo elemento verdadeiramente eficaz para a construção de uma sociedade democrática, que leva em consideração as diversidades, respeitando a individualidade do sujeito, aptos a refletir sobre a sociedade e capaz de inserir-se nessa sociedade. Então de acordo com alguns educadores, a educação escolarizada deveria ser sustentada no indivíduo integrado à democracia, o cidadão atuante $\mathrm{e}$ democrático.

${ }^{133}$ John Dewey. Democracia e educação, 1957, p. 350. 
Foi por meio do pensamento escolanovista que se deu a modernização do ideário liberal nacional, atendendo aos objetivos da classe dominante e às aspirações reformistas das classes médias, indicando democracia e progresso para as classes inferiores. A instrução era vista como elemento (com)formador do indivíduo e criadora do homem moral. A educação atrelou-se à cidadania, instituindo sua imprescindibilidade para a formação do cidadão. Via-se a ciência como os rudimentos de uma cultura letrada.

Neste contexto liberal da nova República a educação metodista fincará suas estacas em solo brasileiro procurando oferecer sua contribuição à formação de novas gerações sob o ideário

\section{5}

\section{A Educação Metodista no Brasil e a Conferência Anual}

A educação Metodista inseriu-se no Brasil no período transitório da Monarquia para a República. A educação formal no Império estava restrita à elite representada pela oligarquia agrária que enviava os filhos para estudarem na Europa, ou contratavam professores brasileiros, também muito valorizados pelas famílias brasileiras nobres. Naquela época poucas mulheres tinham acesso à educação. Na ocasião, a instrução era oferecida pela religião oficial, o catolicismo romano.

Assim, segundo Mesquida, a pedagogia metodista no Brasil será a Pedagogia da Diferença, pois equivocadamente os missionários consideravam o catolicismo opressor, enquanto a proposta metodista seria libertadora; o catolicismo levaria à perdição, enquanto o metodismo anuncia a salvação; o catolicismo seria falso e enganador, enquanto o metodismo seria fonte de luz; o catolicismo seria a fonte da ignorância e superstições, enquanto o metodismo trazia a civilização através da educação e da ciência; o catolicismo seria a causa do atraso do país, e o metodismo representaria o progresso. Esta mentalidade justifica-se pelo momento histórico de tensões e hostilidades. Entretanto, hoje 
pode-se constatar que esta visão dos missionários metodistas era parcial, e em alguns momentos até preconceituosas, desconsiderando os benefícios que o ensino católico trouxe à nação brasileira.

O metodismo de origem norte-americana não tinha como prioridade a evangelização no conceito mais usual de proselitismo, mas na formação de uma mentalidade. Por isso as escolas metodistas iniciarão o trabalho de cima para baixo, do ponto de vista de classes sociais:

"Através da escola nossa obra se tornará atraente para os estudantes, e seus pais nos ajudarão a superar progressivamente os obstáculos que freiam a obra metodista e, por conseguinte, ajudará a anular a influência da Igreja romana, dando-nos a possibilidade de convencer as pessoas de que nós somos portadores do bem; isso poderá atrair para a nossa obra a classe para a qual nós queremos anunciar a verdade do Evangelho. Por que essa escola recebe apoio das melhores famílias, poderemos assumir o comando da educação feminina no Brasil, modelar a mentalidade das mulheres e de seus filhos, o que contribuirá para destruir dogmas frágeis, mas tirânicos, da Igreja Católica". ${ }^{134}$

Ao assumir o modelo norte-americano, o projeto educacional republicano brasileiro tentou construir uma nova lógica que convergisse a cultura local e a cultura das elites, mas ao contrário disso só salientou essa dicotomia. Os metodistas também não conseguiram diluir essa dicotomia peculiar da tradição brasileira, onde a educação vivia desvinculada da cultura nacional.

Em setembro de 1886, foi realizada a Conferência Anual (que hoje equivale a um Concílio), na capela da Igreja Metodista no Catete, em 16 de setembro de 1886, abrangendo dois temas principais: A área geográfica ocupada pela Igreja Metodista e a Constituição da Assembleia Metodista Anual. O "território metodista" no Brasil possuía quatro centros principais Nos quatro centros principais e em outros menores contavam-se 214 membros arrolados e seis pregadores locais:

1. Catete (Rio de Janeiro) - com duas congregações: uma estrangeira (com pregação em inglês) e outra brasileira, totalizando 63 membros. Um novo templo foi inaugurado em 5 de setembro de 1886, às vésperas da Conferência Anual.

${ }^{134}$ Christian Advocate, 27 de outubro de 1883, p. 11. 
2. São Paulo - Tinha apenas 13 membros arrolados, mas sem propriedades.

3. Juiz de Fora e Piracicaba - possuíam templos modestos, com 31 e 70 membros, respectivamente.

A Conferência Anual formulava a estratégia da região; os itinerantes (pregadores), que eram avaliados com relação ao seu trabalho e seu caráter e recebiam nomeação do Bispo. Um motivo primordial tornava essencial a organização de uma Conferência Anual seria reconhecer, com urgência, o metodismo brasileiro como pessoa jurídica, uma ênfase da $2^{\mathrm{a}}$ Conferência Anual Missionária, em julho de 1886. O governo imperial não reconheceu a Junta de Missões como pessoa jurídica. Somente na República que a Conferência Anual foi reconhecida como pessoa jurídica, para o desapontamento da liderança da Igreja Metodista Episcopal da América do Norte, daquela época.

A necessidade de organizar uma Conferência foi reconhecida pela Conferência Geral da Igreja Metodista Episcopal Sul, que deu autorização para o primeiro Bispo visitar a Missão e constituir a Conferência. Em virtude dos poucos membros com que a Conferência contaria o bispo Granbery quase desistiu de realizá-la. Os obreiros nacionais ainda não eram itinerantes; Newman foi rebaixado para pregador local na Conferência dos EUA; Koger havia morrido, em janeiro de 1886 e Ransom foi "devolvido" em agosto daquele ano.

Apenas o chamado "Trio de Ouro" participou do evento: Kennedy (evangelista, construtor de igrejas e o historiador do metodismo brasileiro, com o livro "Cincoenta Annos de Methodismo no Brasil"); Tarboux (pregador e pastor das principais Igrejas Metodistas e primeiro bispo da Igreja Metodista do Brasil, eleito em 1930) e Tucker (agente da Sociedade Bíblica Americana e fundador do Instituto Central do Povo). O Bispo convocou os três membros para a organização da Conferência Anual, muito simples e breve, mas um dos momentos decisivos do metodismo brasileiro. 


\section{6}

\section{O Ideário da Educação Metodista no Brasil}

No Brasil, as instituições metodistas de ensino iniciaram seus trabalhos no final do século XIX, inovando com a formação educacional de meninas, jovens e mulheres. Em sua política de consolidação da missão e na busca da afirmação da identidade metodista no Brasil, a Sociedade Missionária das Mulheres da Igreja Metodista Episcopal do Sul da América do Norte, implantaram quinze projetos em todo o país, até o início do séc.XX.

No ano de 1881, fundou-se no interior de São Paulo, na cidade de Piracicaba - o Colégio Piracicabano, pela Professora Martha Watts. Em 1885, em Porto Alegre, o Colégio Americano, sob a direção do reverendo João Correia e da educadora metodista uruguaia Carmen Chacona. Tem-se também a fundação de instituições de ensino para a educação de meninas e moças, como a Escola do Alto, no Rio de Janeiro (mais tarde denominada Colégio Metodista Bennett 1888), Colégio Americano Fluminense (1892), Colégio Mineiro (1891), e Colégio Americano de Petrópolis (1895), Colégio Metodista de Ribeirão Preto (1899), Colégio Izabella Hendrix em Belo Horizonte (1904), Colégio Centenário Santa Maria, no Rio Grande do Sul (1922)

Os Colégios Metodistas diferenciavam-se dos demais modelos vigentes deste período pela didática implementada em suas aulas e também pelo caráter público das demais atividades escolares. Os métodos de ensino sistematizavam o ensino-aprendizagem a partir de uma perspectiva de teoria e prática, explorando os interesses e as necessidades dos alunos. É interessante ressaltar, também, que em muitas escolas metodistas as classes eram mistas, porém, o regime de internato era oferecido especialmente para as meninas.

(...) a proposta pedagógica de valorização do indivíduo, da educação centrada no aluno e nas suas necessidades básicas, (...) foi muito difundida entre os educadores (...) ensino que valoriza o intelecto, o corpo e o espírito, o tripé educacional sempre difundido por John Wesley, seria grande contribuição dos metodistas para a escola brasileira do séc. XX. ${ }^{135}$

\footnotetext{
${ }^{135}$ ALMEIDA, VASNI. A Educação Escolar Metodista no Nordeste Paulista. 2a . Edição Ribeirão Preto. Colégio Metodista de Ribeirão Preto, 2004.
} 
Muitos educadores metodistas deixaram a segurança econômica de seu país de origem nos Estados Unidos, o convívio com suas famílias, a facilidade de estudo para seus filhos, para enfrentar imensas dificuldades num país distante com clima, língua e costumes tão diferentes, além das epidemias periódicas que ocorriam, como a febre amarela. Muitos, inclusive, ceifados por estas. Qual a motivação que os fazia escrever para os EUA solicitando mais educadores e mais pregadores metodistas?

Seguiremos a proposta de Novaes, buscando os relatos do jornal oficial da Igreja Metodista no Brasil - Expositor Cristão ${ }^{136}$, como fonte desses relatos e informações:

"A razão e a História nos demonstram que devem estar unidas a Escola e a Religião e desta conexão depende sua força e eficácia para a existência e prosperidade da ordem moral sobre a terra." ${ }^{, 137}$

Pode-se dizer que a propagação da "fé civilizatória" foi o grande objetivo da implantação das escolas. Se no protestantismo em geral a fé e a razão estão atreladas, verifica-se essa característica especialmente no Metodismo, pois considera o conhecimento científico importante elemento para o progresso da sociedade.

"A nossa Igreja-Mãe tem estabelecido no território da nossa conferência diversas escolas. E isso é parte de seu plano mundial. Qual é o fim dessas escolas? Que atmosfera devem ter? A do livre pensamento da Universidade? A docilidade do gymnasio? Ou a prática das escolas profissionais? A nós parece que nossas escolas, sendo estabelecidas para serem meios de propaganda da nossa fé, devem ter francamente uma atmosfera evangélica, bíblica e methodista. A nossa missão no Brasil é bem claramente determinada: é a de estabelecer a Igreja Metodista; não como um fim, porém, como o melhor meio que conhecemos para estabelecer o Reino de Deus - reino de justiça, retidão e paz.

(...)

Temos de acrescentar aqui que nosso trabalho de instrução tem em vista três fins práticos:

a) Desfazer preconceitos contrários à nossa propaganda ...;

b) Instruir nossos filhos e os de nossos amigos e adeptos numa atmosfera cristã;

c) O fim mais importante das nossas escolas é, talvez, preparar trabalhadores e literatura para nossa propaganda. Nós não devemos amoldar cursos, nem

\footnotetext{
${ }^{136}$ O jornal EXPOSITOR CRISTÃO é o jornal oficial da Igreja Metodista no Brasil desde 1886 em funcionamento até os dias atuais.

${ }^{137}$ Expositor Christão: 1903, Volume XVIII, n. 4, p. 1.
} 
determinar os nossos trabalhos em conformidade com as exigências do governo federal que segue as praxes arbitrárias pelos jesuítas ou os dogmas enunciados por Comte...", 138

Os educadores metodistas estavam absolutamente convictos que tinham a responsabilidade da transformação do Brasil, construindo na mocidade brasileira alicerces do progresso, da moralização, da civilização pautada na evolução social como elementos regeneradores da nação. Daí a crença liberal no poder redentor da educação como ação (com)formadora do indivíduo. Exemplo disso retrata-se no fato da Sociedade Missionária das Mulheres da Igreja Metodista Episcopal do Sul implantar quinze projetos em todo o país, até o início do século XX.

Neste período histórico o método de ensino que vigorava no Brasil estava baseado e inspirado na pedagogia jesuítica, herança centrada no Ratio Studiorum (promulgado na Contra-Reforma, na Europa, 1599). Este documento organizava a aprendizagem em três princípios básicos: a unidade da matéria, o método e o professor. Nele o ensino clássico centrava-se na transmissão do conhecimento através da memorização orientada pelo mesmo professor por muitos anos, caracterizando-o como mestre.

No início do séc.XX, as instituições de ensino estavam organizadas e dirigidas pela Igreja Metodista Norte Americana, visto que a Igreja Metodista no Brasil ainda ensaiava seus primeiros passos. A influência educacional era reconhecida nos lugares onde a Igreja crescia.

No Rio Grande do Sul, onde o trabalho educacional metodista já funcionava desde 1885, aconteceu o movimento de resistência às missões protestantes, lideradas por Dom João Becker - arcebispo da Igreja Católica, no período de 1912 à 1946. Esse movimento confessional Católico foi chamado de "catolicismo político" pelo pastor luterano Hermann Dohms. Esse movimento queria exigir a identificação do povo brasileiro com a Igreja Católica, apesar da separação entre o Estado e a Igreja Católica, com a Proclamação da República. Dizia no seu discurso que as instituições protestantes de ensino queriam "protestantizar para melhor americanizar".

\footnotetext{
${ }^{138}$ Expositor Christão: 1911, no. 29, p.1.
} 
"Como os protestantes norte-americanos fazem propaganda de sua seita em seus Colégios e por meio de seus Colégios, é dever nosso chamar continuamente contra estas escolas, que são subterrâneos onde se prepara manhosamente a miragem da unidade nacional, e, portanto, de sua soberania e liberdade." 139

Em meio às profundas mudanças organizacionais e políticas que a Igreja Metodista do Brasil atravessa na década de 1930, ainda pode-se constatar nos documentos conciliares, a presença das missionárias e dos missionários norteamericanos nos trabalhos desenvolvidos nas instituições educacionais, bem como nas Igrejas, onde desempenhavam o ministério pastoral, em todo o território nacional. Nos anos seguintes, desenvolveu-se a formação de liderança brasileira laica e religiosa nas áreas de evangelização, educação, e ação social, através do trabalho realizado pelos grupos societários que reuniam grupos de homens, mulheres e jovens. Outro trabalho importantíssimo que ajudou no desenvolvimento da liderança da Igreja para atuar em suas diversas áreas de ação na sociedade de um modo geral foi a Escola Dominical. Esta, por sua vez, reunia regularmente aos domingos pela manhã um grupo grande de fiéis, especialmente juvenis e crianças, que eram agrupados por faixa etária, facilitando assim o desenvolvimento da comunidade.

Enquanto isso, em todo o país discutia-se sobre a defesa da educação pública, laica e gratuita, em contraponto às confessionais, que na ocasião ofereciam educação no ensino elementar.

A educação metodista chega junto com a evangelização, marcando tanto a prática eclesial quanto ao serviço à sociedade brasileira.

"O programa educativo é uma das primeiras e mais importantes expressões da obra missionária. A natureza e a profundidade das mudanças que se quer introduzir na sociedade não condizem com o analfabetismo dos conversos nem com a pouca instrução reinante. É necessário que o protestante seja capaz de, pelo menos, ler a Bíblia e certa literatura religiosa e a comunidade global deve valorizar e expandir a educação, considerada a mola principal da ascensão social". ${ }^{140}$

\footnotetext{
${ }^{139}$ Estrela do Sul, Porto Alegre, 30 de março de 1924. In: GEERTZ.1999. p.161.

${ }^{140}$ Jether P. Ramalho. Prática educativa e sociedade: Um Estudo de Sociologia da Educação, 1976, p. 69.
} 
No solo brasileiro ávido por inovações, a educação protestante desenvolveu-se rapidamente, com a adesão da elite ansiosa por progresso.

"Nosso trabalho educacional é muito importante não apenas pelas vantagens de uma educação evangélica, mas também por causa dos urgentes pedidos que nos chegaram para abrir escolas". ${ }^{141}$

A arquitetura dos colégios era fabulosa para a época: salões nobres, bibliotecas e mobílias importadas. Os alunos tinham que aprender inglês para se comunicarem com os professores e ler os livros traduzidos da América. Há um relato de Pedro de Moraes de Barros, que foi aluno do colégio Piracicabano, que escreve que no primeiro ano já falavam inglês para poderem se comunicar com as professoras e missionárias. Os poemas declamados, os hinos cantados, tudo deveria ser em inglês. ${ }^{142}$ Além disso, outra inovação que se destaca é a prática da Educação Física, os jogos, as competições, no qual o esforço de cada um contribui para o resultado do grupo. Era uma das estratégias pedagógicas.

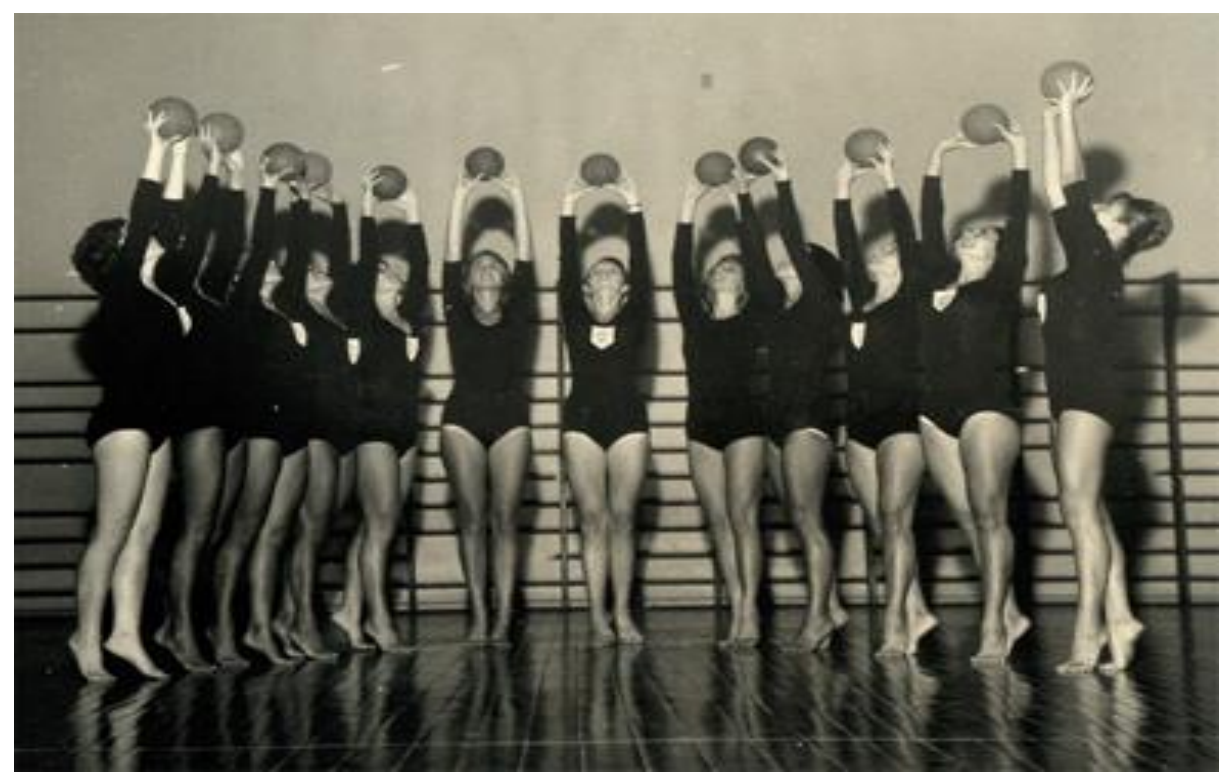

FIGURA 12 - Aula de Educação Física no Colégio Metodista Bennett - 1950.

Até o início do século XX, os colégios metodistas estavam organizados e dirigidos pela Igreja Metodista Norte Americana, através de seus missionários,

\footnotetext{
${ }^{141}$ Methodist Episcopal Church, South Board of Missions. Anual Report: 1889, p. 51.

${ }^{142}$ Atualidades Pedagógicas, SP, CEN, 1956, p. 37-38.
} 
visto que a Igreja Metodista no Brasil ainda ensaiava seus primeiros passos de autonomia. A influência educacional era reconhecida nos lugares onde a Igreja crescia.

\section{7}

\section{Escolas Paroquiais}

Há um outro movimento importante que deve ser destacado. Ele iniciouse timidamente em 1883, e foi revigorado em 1918: o movimento das Escolas Paroquiais. Impulsionada pela Pastoral de D. Leme, em 1916, a Igreja Católica procura alcançar as camadas médias da população e as classes populares, através da educação, fundando as escolas paroquiais. Diante desse projeto, a Igreja Metodista reage reativando as escolas paroquiais que estavam fechadas e reabrindo outras. O outro exemplo clássico deste serviço social é o Instituto Central do Povo, fundado no Rio de Janeiro (então capital da República) em 1910, com suas atividades até os dias atuais.

As escolas paroquiais se alinhavam em três objetivos principais:

1. Ensinar a ler e escrever;

2. Formar quadros para a Igreja e o país;

3. Selecionar os melhores alunos concedendo-lhes bolsas para continuarem os estudos nos colégios metodistas.

Apesar das escolas paroquiais serem pagas, os valores eram pequenos e acessíveis para o público para o qual se destinavam.

\section{8}

\section{A Autonomia da Igreja Metodista do Brasil e suas Instituições de Ensino}

A autonomia da Igreja Metodista no Brasil e a construção do discurso sobre a unidade e soberania nacional acontecem no mesmo período histórico. O 
contexto internacional retratava a quebra da bolsa de valores de Nova Iorque e a consequente exigência da redefinição das missões norte-americanas metodistas aqui no Brasil.

O historiador Antônio Joaquim Severino analisa este período da história da educação brasileira, onde a Igreja Católica e suas escolas enfrentam o crescimento das instituições de ensino das Igrejas Evangélicas, assim como o início de uma política pública de ensino, pelo Estado brasileiro. Em 1930, o presidente provisório da República, cria, através do decreto 19.402/1930, o Ministério dos Negócios da Educação e Saúde Pública.

(...) do início da colonização até a Revolução de 1930, parece que a categoria de "público" se esvai no contexto cultural, uma vez que a educação, ao longo da Colônia, do Império e das primeiras décadas da República fica totalmente entregue ao domínio da Igreja. (...) A educação quase se confunde com a evangelização católica, e (...) o princípio do bem comum, categoria tão forte no ideário teológico do catolicismo, não tem no seu postulado comunitarista uma dimensão pública (...) o comunitarismo cristão exime o poder estatal de qualquer iniciativa político administrativa de uma gestão universalizante da educação (...) o que resguardou e legitimou a ausência do embrionário aparelho estatal brasileiro no atendimento das necessidades educacionais $(\ldots . .)^{143}$

Neste período histórico estão sendo discutidas as propostas do Manifesto dos Pioneiros da Educação (divulgadas em 1932) e os ideais da Escola Nova. A educação metodista já correspondia aos desejos das formações das elites regionais republicanas, inspiradas no modelo de democracia dos Estados Unidos da América (desde o final do século XIX). Essa corrente pedagógica inovadora, naquele momento, refletia os ideais do progresso encontrados nos discursos dos educadores em todo o país.

A educação nova, alargando sua finalidade além dos limites das classes, assume, com uma feição mais humana, sua verdadeira função social, preparando-se para formar a "hierarquia democrática" pela "hierarquia das capacidades", recrutadas em todos os grupos sociais, a que se abrem as mesmas oportunidades de educação. Ela tem por objetivo organizar e

\footnotetext{
${ }^{143}$ SEVERINO, Antônio Joaquim. O público e o privado em categoria de análise de educação. In: SILVA, Tânia Mara da et AL (Org.) O Público e o Privado na Educação Brasileira: Concepções e Práticas Educativas. Campinas. HISTEDBR/UNISAL, 2005.p.32.
} 
desenvolver os meios de ação durável, com o fim de "dirigir o movimento natural e integral do ser humano em cada uma das etapas de seu crescimento" de acordo com certa concepção de mundo. ${ }^{144}$

Rosa Gitana Krob Meneghetti, analisando as características da educação metodista afirma que neste período, esta tem características "mais humana, democrática, pragmática e flexível às mudanças”. Se pensarmos bem, essas características são fundamentais para a formação de sujeitos para uma sociedade em processo de industrialização. Vê-se então, as convergências entre as propostas dos pioneiros da educação e os objetivos das práticas pedagógicas metodistas.

Cito novamente Antonio Joaquim Severino para comentar sobre este período:

Apesar da resistência e oposição da Igreja Católica, a partir da Revolução de 1930, o Estado brasileiro consolida-se e implanta o sistema público de ensino. Esse conflito fica explícito ao longo da discussão do Projeto de Lei de Diretrizes e Bases (LDB), de 1946 a 1961, documento que registrou, de forma bem nítida, o compromisso que se firmou, no âmbito da política educacional, entre católicos e liberais. Esse conflito acaba levando a Igreja a posicionar-se favoravelmente a um modelo privado de gestão educacional. ${ }^{145}$

As mudanças nas Instituições de Ensino da Igreja Metodista do Brasil ocorridas em consequência de sua autonomia interna e também devido ao contexto político nacional foram percebidas com maior consistência no período entre 1950 até 1960, quando muitos missionários foram substituídos por liderança brasileira da Igreja. Na época as lideranças educacionais reproduziam a formação liberal trazida pelos missionários.

É bom destacar que o período de 1945 a 1964 foi um período de grandes mudanças. Ocorreu o término da segunda guerra mundial, a criação da ONU (Organização das Nações Unidas), a criação do Estado de Israel, a guerra fria entre EUA e Rússia, a reordenação da economia mundial sob o domínio absoluto dos Estados Unidos. Já no Brasil, em 1942, o Ministro Souza Costa assinou diversos acordos, em Washington, selando definitivamente a aproximação com os Estados Unidos da América. Vê-se a transição de uma era ditatorial (Getúlio

\footnotetext{
${ }^{144}$ ROMANELLI, Otaíza de Oliveira. História da Educação no Brasil. Período da Segunda República. O Manifesto dos Pioneiros da Educação Nova: 1932. São Paulo: Editora Vozes, Edição 34, 2009.

${ }^{145}$ SEVERINO, 2005, p.33
} 
Vargas) para um governo democrático (governo Dutra), eleição da Assembleia Constituinte (1945) e nova Carta Constitucional (1946).

Dá-se o nascimento de uma nova elite brasileira: ostentadora e individualista. Gabriel Cohn ${ }^{146}$ dá o seguinte depoimento sobre os grupos detentores da parcela dominante da renda, na época:

"Longe de serem compostos predominantemente por empresários interessados na expansão de seus empreendimentos, eram formados em boa medida por exportadores, importadores (enriquecidos pelos lucros especiais propiciados pela situação da guerra) e mesmo industriais ainda portadores de uma mentalidade de consumo, cuja preferência ia para os gastos pessoais em detrimento daqueles mais produtivos. ${ }^{1147}$

Com a urbanização do país (resultado da industrialização do período), as políticas públicas implementadas, visando atender as demandas da população, incorporaram a tradição educacional liberal. Neste novo cenário, o projeto político pedagógico das escolas metodistas foi se transformando de inovador à tradicional.

Ora, se a educação é um fator de transformação, parece que as instituições metodistas de ensino mostram-se alheias quanto aos problemas do país e de seu povo, pois outras preocupações ocupam a atenção das lideranças educacionais da época, como por exemplo: a declarada intolerância religiosa, ainda tão presente neste período que parece só minimizar a partir do pontificado de João XXIII e do Concílio Vaticano II, na primeira metade da década de 60 . Antes disso, as relações entre metodistas e católicos romanos eram de total enfrentamento, onde não raramente, calúnias e inverdades só encontravam paradeiro nos tribunais, inclusive no cotidiano das escolas.

$\mathrm{Na}$ ótica dos protestantes e escolanovistas, enquanto o ensino católico se caracterizava por ser tradicional e propedêutico, o ensino ministrado nas escolas protestantes sinalizava uma outra possibilidade com perspectiva políticoeducativa mais concordes com os ideais republicanos. (...) propunham-se engajar seus alunos na luta pelo progresso nacional, a partir de uma visão onde a razão, a

\footnotetext{
${ }^{146}$ Gabriel Cohn é um sociólogo brasileiro, especialista na obra de Max Weber. É graduado em Ciências Sociais pela Universidade de São Paulo, em 1964. Obteve os graus de mestre, doutor e livre docente, na mesma Universidade.

${ }^{147}$ DIAS, M. N. et alli, Brasil em Perspectiva. São Paulo: Difusão Européia do Livro, 1968, p.341
} 
base do pensamento científico é o motor propulsor de sua perspectiva educacional. ${ }^{148}$

Em meio às profundas mudanças organizacionais e políticas que a Igreja Metodista do Brasil atravessa na década de 1930, ainda pode-se constatar nos documentos conciliares, a presença das missionárias e dos missionários norteamericanos nos trabalhos desenvolvidos nas instituições educacionais, bem como nas Igrejas, onde desempenhavam o ministério pastoral em todo o território nacional. Nos anos seguintes, desenvolveu-se a formação de liderança laica e religiosa nas áreas de evangelização, educação e ação social, através do trabalho realizado pelos grupos societários que reuniam grupos de homens, mulheres e jovens. Além da Escola Dominical. Esta, por sua vez, reunia regularmente aos domingos pela manhã um grupo grande de fiéis, especialmente juvenis e crianças, que eram agrupados por faixa etária, facilitando assim o desenvolvimento da comunidade.

Enquanto isso, em todo o país discutia-se sobre a defesa da educação pública, laica e gratuita, em contraponto às confessionais, que na ocasião ofereciam educação no ensino elementar.

No final da década de 40, os colégios metodistas reconhecidos como excelentes, se constituem como referências e modelos para os próprios órgãos públicos. O jornal Expositor Cristão, fará uma série desses registros, como poderemos ver a seguir:

"O Colégio Americano, seguindo os mais modernos preceitos de pedagogia, não pretende ser, jamais, um colégio grande pelo número de alunas matriculadas, mas pela qualidade de ensino que ministra e pela orientação espiritual e moral que proporciona às suas alunas". ${ }^{149}$

Ângelo B. Rodrigues, afirmou:

"Em matéria de Colégios, a Igreja Metodista está de parabéns. Porém num vasto território como o nosso, cuja população é semianalfabeta, e com pouco mais de um século de educação pública, ainda há muito que fazer. (...) Os Colégios Metodistas realizam um programa de grande alcance cultural, cívico e alguns, acentuadamente espiritual". ${ }^{150}$

\footnotetext{
148 MENEGHETTI, 1998, p.153.

149 Jornal Oficial da Igreja Metodista - EXPOSITOR CRISTÃO, 25-09-1947, p. 2.

150 Jornal Oficial da Igreja Metodista - EXPOSITOR CRISTÃO, 27-01-1949, p. 4.
} 
O padrão das Escolas Metodistas, tanto por sua pedagogia adotada quanto por seu currículo, serviam de padrão às autoridades do país. Porém, em 1958 , B. P. Bitencourt publica ampla matéria enfocando problemas de administração nestas instituições de ensino. Seu texto também retrata o cunho evangelístico na ação dos Colégios:

"Alguns destes estabelecimentos já perderam há muito sua finalidade, pois foram instituídos como meio evangelizante e hoje nem mesmo uma assembleia semanal, para não dizer diária, realizam. Nossos colégios são mantidos, alguns deles, com muito sacrifício nosso... e esse sacrifício só se justifica se ele visa levar seus alunos a uma experiência com Cristo e a uma nova vida nEle. Do contrário, educar pelo simples desejo de ensinar geografia e matemática, não vale à pena". ${ }^{151}$

No dia 13 de abril de 1945, o Bispo César Dacorso Filho trata da necessidade em criar uma Universidade Metodista no Rio de Janeiro, no bairro de Inhoaíba, nas terras do patrimônio de Ana Gonzaga, que as doou para a Igreja.

"Precisamos de uma Universidade profundamente religiosa, primordialmente aos filhos dos crentes, e não para os filhos do Presidente da República e para os filhos dos graúdos. A Igreja precisa dar amparo aos filhos da Igreja".

Na década de 1950 a liderança da Igreja Metodista apresenta ao Bispo Ivan Lee Holt e ao Dr. Marshal Stell, um documento onde justificava o empreendimento do projeto universitário no Brasil, com 14 considerandos para que a Igreja Mãe (Metodista Episcopal) assumisse esse projeto. "Precisamos urgentemente de uma Universidade Metodista no Brasil (...)" 153

Em meados da década de 50 a Assembleia do Conselho Geral de Instituições Metodistas de Ensino (COGEIME), discute e pontua preocupações com otimismo para a formação de uma Universidade Metodista na Brasil. Estudase a possibilidade de criar as Faculdades nos Colégios Metodistas, estrategicamente escolhidos.

As mudanças nas Instituições de Ensino da Igreja Metodista do Brasil ocorridas em consequência de sua autonomia interna e também devido ao contexto político 1960, quando muitos missionários foram substituídos por liderança brasileira da Igreja.

\footnotetext{
${ }^{151}$ Jornal Oficial da Igreja Metodista - EXPOSITOR CRISTÃO, 21-08-1958, p. 8.

${ }^{152}$ Ibid., 31-05-1945, p. 2.

${ }^{153}$ Ibid., 2 e 9-08-1945, p. 5.
} 
No ano de 1964, marco histórico tanto na política do país como na ação das instituições metodistas de ensino, pois é neste ano que o povo brasileiro sofre o autoritarismo do Golpe Militar e, curiosamente, num espaço de duas semanas da queda da democracia brasileira, acontece a aula inaugural dos cursos superiores do Instituto Educacional Piracicabano, embrião da primeira Universidade Metodista no Brasil. Esse sonho, finalmente, fez-se realidade.

No ano de 1968, os bispos católicos adotam pela primeira vez a expressão "educação libertadora" e a caracterizam como o processo que "converte o educando em sujeito do seu próprio desenvolvimento". 154

Na década de 1970, o metodismo brasileiro passou por uma avaliação de suas práticas missionárias e educativas. É neste momento que promulga um documento denominado Credo Social da Igreja Metodista, com o objetivo de valorizar a tradição wesleyana, bem como orientar os metodistas sobre as discussões dos problemas sociais do país.

Em meio ao período da ditadura militar, e todos os reflexos que gerou na Igreja Metodista e suas instituições de ensino, o Bispo Paulo Aires comenta:

\begin{abstract}
A teologia da obra educacional metodista no Brasil foi de índole liberal, em que pese a predominância no interior da Igreja de discursos e práticas eclesiais próprias do pietismo norte-americano (...). Em seu núcleo central achava-se a convicção própria do liberalismo de que a educação do ser humano para o bem é o caminho para o aperfeiçoamento social e moral da humanidade. A construção de um mundo justo e bom é possivel desde que o ser humano receba uma adequada educação. ${ }^{155}$
\end{abstract}

Neste período Paulo Freire propõe um diálogo entre a pedagogia e a teologia, não só no país, mas na América Latina. Foram produzidas duas obras significativas: Pedagogia do Oprimido (de Paulo Freire) e Teologia da Libertação (de Gustavo Gutiérrez).

Danilo Streck analisa as relações entre a teologia e a pedagogia, e comenta:

Estas obras sinalizam que do chão de um continente secularmente maltratado pode e precisa surgir uma nova prática, acompanhada de uma nova reflexão

\footnotetext{
${ }^{154}$ GANDIN, Danilo. Escola e Transformação Social. Petrópolis: Vozes, 1988. p.130.

${ }^{155}$ MATTOS. Revisa do COGEIME. Ano 2000, p.59.
} 
teológica e pedagógica. Descobre-se que as teorias pedagógicas e teológicas importadas simplesmente não correspondem aos desafios da realidade latinoamericana. Para isso não há necessidade de negar ou anular a contribuição de teólogos e educadores do Primeiro Mundo, mas busca-se a sua superação no confronto com os problemas do povo. ${ }^{156}$

Em 1982, a Igreja Metodista reúne-se em seu XIII Concílio Geral, contando com representação de todo o país, e recebe a apresentação do documento denominado, Plano para a Vida e a Missão da Igreja (PVMI). Na ocasião aprovase a matéria "Diretrizes para a Educação da Igreja Metodista" (DEIM). Este documento é fruto do trabalho de um grupo de redatores que representa os mais diversos segmentos da Igreja, resultado de discussões e reflexões anteriores.

Os Cânones da Igreja Metodista faz a seguinte citação sobre o tema:

"Na continuidade de um processo iniciado há longo tempo e de projetos elaborados anteriormente, e tentando responder a anseios já existentes, a Igreja Metodista iniciou, em 1979, um processo formal para definir posições que servissem como diretrizes para a tarefa educativa de suas escolas". ${ }^{157}$

\section{9}

\section{Diretrizes para a Educação da Igreja Metodista: Uma Proposta Libertadora}

O documento Vida e a Missão da Igreja (PVMI), já mencionado anteriormente, contém o discurso da Igreja sobre sua prática teológico-pastoral e educacional. Ele está dividido em três partes:

1) Plano para a Vida e a Missão da Igreja;

2) Plano para as Áreas de Vida e Trabalho;

3) Diretrizes para a Educação da Igreja Metodista.

\footnotetext{
${ }^{156}$ STRECK, Danilo Romeu. Correntes Pedagógicas: Aproximações com a Teologia. Petrópolis: Vozes, 1994. p. 26.

${ }^{157}$ DIRETRIZES PARA A EDUCAÇÃo NA IGREJA METODISTA. Cânones da Igreja Metodista. São Paulo: Colégio Episcopal, 1992, p. 95.
} 
O reverendo e Dr. Clory Trindade de Oliveira (teólogo e historiador da Igreja) analisa o documento e observa que o mesmo surge com reflexão da Igreja desde 1960, considerando o contexto do Concílio do Vaticano II, da ditadura militar, do desenvolvimento da teologia da libertação, que segundo ele foi marco inspirador para esta elaboração. ${ }^{158}$

Oliveira faz uma análise considerando o fato do metodismo sempre privilegiar a criação de escolas em todas as comunidades onde desenvolveu sua ação evangelizadora: Na Inglaterra, no século XVIII, o movimento metodista caracterizou-se pela ênfase soteriológica, segundo o qual, a educação era o instrumento evangelizador para a salvação; nos Estados Unidos, caracterizou-se pela ênfase eclesiológica, e transpunha os limites da comunidade de fé, construindo as bases morais da sociedade americana; já no Brasil, a partir deste documento, fica delineada a sua ênfase missiológica, ou seja, a tarefa educacional da Igreja foi compreendida como um dos instrumentos da missão. ${ }^{159}$

O Bispo Paulo Ayres, comenta:

(...) o metodismo é um movimento religioso confessional evangélico eminentemente educacional, fruto da visão de John Wesley e dos primeiros metodistas sobre o caráter integral do Evangelho. ${ }^{160}$

Como base filosófica da educação metodista, o DEIM afirma que toda a educação se baseia numa filosofia, isto é, uma visão a respeito do mundo e das pessoas. No caso metodista a filosofia é iluminada pela fé, estando por isso, sempre relacionada com a reflexão teológica, à luz da revelação bíblica em confronto com a realidade. Tenta fugir do ideal liberal transmitidos no início pelos missionários metodistas norte-americanos, onde a educação possuía características acentuadamente individualistas: preocupação individualista com a ascensão social, acentuação do espírito de competição, aceitação do utilitarismo como

\footnotetext{
158 OLIVEIRA, Clory Trindade. A Trajetória da Educação Metodista PVMI e DEIM: 20 anos de história. Revista de Educação do Conselho Geral das Instituições Metodistas de Educação, Piracicaba, ano 12, n. 23, p. 15 dez. 2003.

159 OLIVEIRA, Clory Trindade. Dimensões teológicas da educação metodista. In: Encontro Nacional de Pastorais Escolares e Universitárias das Instituições Metodistas de Educação, 1992, Porto Alegre. Texto não-publicado.

${ }^{160}$ MATTOS, Revista do COGEIME, Ano 2000, p. 11.
} 
forma de vida, colocação do lucro como base das relações econômicas, entre outras, tendo como alvo, na perspectiva cristã e como parte de sua missão, oferecer à comunidade e à pessoa uma compreensão de vida e da sociedade, comprometida com uma prática libertadora. Ou seja, cooperar para que os indivíduos e grupos desenvolvam uma consciência crítica da realidade, entendam que o interesse social está acima do individual, e que é necessário exercitar o senso de justiça e solidariedade.

Considerando a herança da tradição metodista, sua preocupação com uma educação libertadora, com valores éticos e cristãos, na busca contínua do diálogo com o mundo à sua volta, as Instituições de Ensino da Igreja Metodista no Brasil, além de sua filosofia educacional e prática descrita nas Diretrizes para a Educação Metodista, também têm a presença das Pastorais Escolares e Universitárias atuando no seu dia-a-dia.

A presença das pastorais foi regulamentada no ano de 1982 pelo Colégio Episcopal, mesmo ano no qual foi aprovado o documento "Diretrizes para a Educação Metodista”. Dentre as diversas funções que exercem, tem o papel de fomentar a consciência crítica, a promoção da vida e da solidariedade.

A tradição educacional da Igreja constituiu-se, historicamente, como identidade confessional metodista. Essa identidade é marcada pela intencionalidade teológica e pedagógica das ações institucionais, que podem ser vistas nos projetos missionários desenvolvidos pelo metodismo em todo o mundo. Ou seja, a confessionalidade metodista também pode ser vista como compromisso educacional com a sociedade, que é compreendida como missão da Igreja. Essa ação não é isolada, mas busca adesão daqueles que estejam dispostos a caminhar juntos na realização do bem comum.

As ideias básicas da filosofia liberal, como: democracia, liberdade individual, liberdade de expressão religiosa com maior participação do leigo, livre exame da Bíblia, apologia ao trabalho, honestidade, eficiência, ... não só estão presentes na catequese metodista, mas também em todo o seu projeto educacional.

De acordo com o COGEIME (Conselho Geral das Instituições Metodistas de Educação), as instituições de ensino da Igreja Metodista estão 
estruturadas e configuram-se como rede, da seguinte forma: A Rede Metodista de Educação, criada oficialmente pelo XVIII Concílio Geral da Igreja Metodista no Brasil em 2006, é constituída pelas unidades de educação básica - educação infantil, ensino fundamental e ensino médio - e educação superior, instituídas pela Igreja Metodista. Juntamente com as unidades de educação teológica e as agências de educação cristã, compõe o Sistema Metodista de Educação, uma das áreas em que a Igreja busca cumprir sua Missão e desenvolver o seu Ministério, exercendo efetiva presença pública e contribuição à sociedade brasileira. Somos mais de meia centena de instituições educacionais distribuídas em todas as regiões e em quase todos os estados do País. Algumas delas são centenárias e foram pioneiras na aplicação de inovações pedagógicas; outras, mais jovens, mas que herdam das primeiras a tradição da educação metodista, com seus processos educacionais comprometidos com princípios e valores, bem como profundamente comprometidos com a busca de qualidade em todos os níveis. Essas instituições educacionais oferecem formação, mais do que mera informação.

A Rede inclui unidades de grande, médio e pequeno porte. Oferece desde a educação infantil até programas de pós-doutorado. Na perspectiva de educação permanente e continuada, desenvolve a educação à distância, projetos direcionados para adultos, a chamada Terceira Idade, bem como expressivos projetos de pesquisa e de extensão. Temos duas universidades, três centros universitários e três conjuntos de faculdades integradas, além de unidades especiais, como a Escola de Música de Piracicaba "Maestro Ernst Mahle".

A Igreja Metodista entende a educação como "o processo que oferece formação melhor qualificada nas suas diversas fases, possibilitando às pessoas o desenvolvimento de uma consciência crítica e seu comprometimento com a transformação da sociedade, segundo a Missão de Jesus Cristo". Esse entendimento está consubstanciado e detalhado no documento DEIM - Diretrizes para a Educação na Igreja Metodista, cujo texto original remonta a 1982 e está atualmente em fase de atualização.

O Cogeime - Instituto Metodista de Serviços Educacionais é a entidade central da Rede, responsável pelo seu planejamento estratégico, coordenação, supervisão, 
integração, acompanhamento e controle de todas as unidades da Rede. Criado em 1967, anteriormente denominado Conselho Geral das Instituições Metodistas de Educação, o Cogeime vem progressivamente incorporando novas atribuições e no XVIII Concílio Geral da Igreja Metodista teve suas competências ampliadas. Ao aprovar um Novo Modelo de Governo para as Instituições Metodistas de Educação, o Concílio Geral reafirmou e ampliou a política de uma maior integração e fortalecimento da Rede, de modo que as unidades sejam capacitadas e acompanhadas para a sustentabilidade em um ambiente extremamente competitivo, permitindo-lhes um processo sistemático de desenvolvimento.

Então, considerando que a Igreja Metodista no Brasil vê a educação como parte de sua missão, as instituições de ensino representam a política da mantenedora junto à sociedade. Entretanto, essa transição trouxe muitas mudanças e transtornos. As instituições perderam sua autonomia de governo para uma gestão centralizada a nível nacional. Muitas demissões, mudanças dos rumos das instituições, cancelamento de cursos oferecidos, foram medidas tomadas, desconsiderando e desconhecendo a cultura regional das instituições, descartando elementos fundamentais das instituições, entre outras coisas. Isso gerou descontentamentos e descaracterização de algumas instituições, pois a ênfase, mais que o projeto ou a missão que a Igreja construiu ao longo de sua história, seria garantir a viabilidade econômica das instituições, numa visão administrativa empresarial.
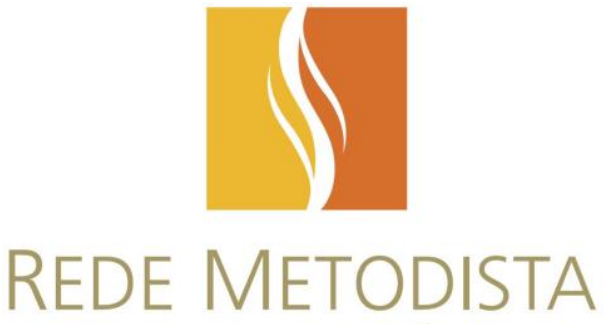

DE EDUCAÇÃO

FIGURA 13 - Logo da Rede Metodista de Educação das Instituições de Ensino no Brasil

Nas Diretrizes para a Educação da Igreja Metodista (DEIM), encontramos seu discurso sobre a educação para a cidadania, como expressão da 
confessionalidade metodista e referencial para suas ações institucionais junto à sociedade brasileira. É nesse viés que se desenham os projetos sociais, envolvendo a comunidade e desenvolvendo uma mentalidade de fraternidade $\mathrm{e}$ solidariedade. Entretanto, o Dr. Ely Eser Barreto César, em Educação $e$ Confessionalidade ${ }^{161}$, compreende que a "crise da evangelização civilizatória" no início dos anos 60, abriu caminho para novos paradigmas entre fé e cultura, com novas referências teológicas, tanto para o projeto da Igreja quanto para seu projeto educacional. Esse novo modelo de "encarnação cultural", além de valorizar a cultura local, reconhece a legitimidade de outras religiões, abre-se para o ecumenismo (macro ecumenismo) em uma perspectiva oposta ao modelo civilizatório anterior que a Igreja defendia. Segundo ele, é nesse novo contexto que se situa o projeto atual das instituições de ensino confessionais da Igreja Metodista. Na concepção contemporânea de missão, a Igreja se move a partir de círculos concêntricos com diferentes extensões de compreensão. Assim, a escola não existe para e nem pode promover a evangelização da Igreja, mas deve contribuir na sinalização do Reino de Deus. Este é o círculo mais abrangente da missão. Segundo ele, é aqui que se situa a confessionalidade da escola da Igreja. É um tema que necessita de vasta discussão não somente entre os acadêmicos, mas dos educadores metodistas, da liderança e das bases da Igreja. Atualmente tem-se um hiato entre o que os teóricos argumentam e o que a Igreja conciliar aspira com suas instituições de ensino. A Igreja aspira uma ação mais evangelística explicitando a fé cristã e tradição metodista. Uma presença mais marcante na vida de nossas escolas, inspirada em John Wesley guardada as devidas proporções da distância dos momentos históricos e culturais.

Seguindo a proposta inicial dos Colégios Metodistas numa prática educacional onde cada um deve ser agente de transformação social, participando da construção do mundo criado por Deus, a partir dos valores do Reino de Deus, citamos as palavras de seu grande mentor, John Wesley:

\footnotetext{
${ }^{161} \mathrm{O}$ texto "Educação e Confessionalidade" foi proferido pelo Dr. Ely Eser Barreto Cesar na Assembleia da ALAIME (Associação Latino-Americana de Instituições Metodistas), no ano de 1997.
} 
Faça todo o bem que você puder Por todos os meios que puder Por todas as maneiras que puder Em todos os lugares que puder Em todos os momentos que puder A todas as pessoas que puder Contanto que sempre o faça. John Wesley (1703 - 1791)

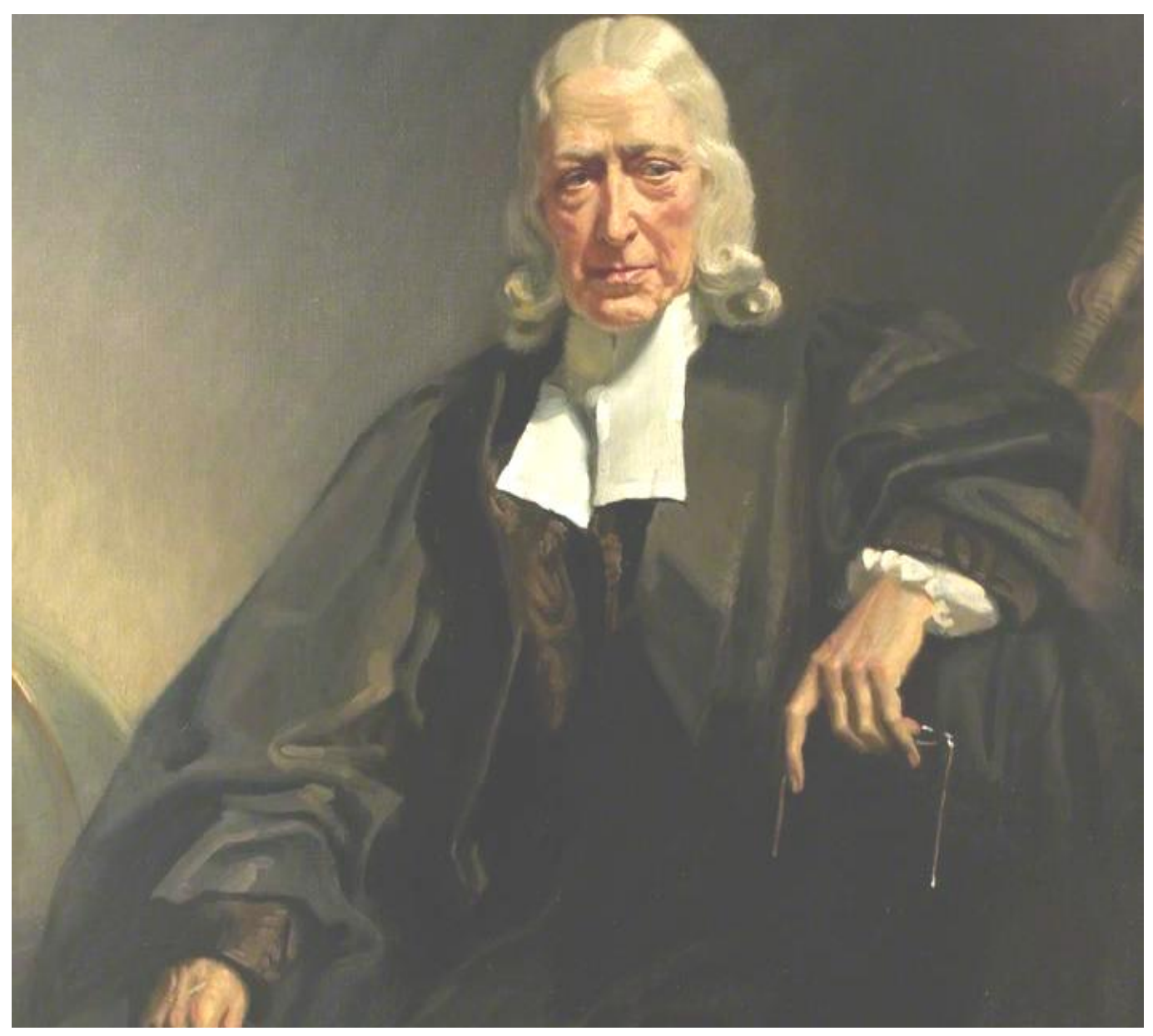

FIGURA 14 - John Wesley em sua velhice. 


\section{5 \\ Conclusão}

"(...) no solo es coherente sino que entiendo como un mandato del Evangelio. Es recuperal al hombre completo, integrado, dejando atrás la mutilada visión parcial del "homo economicus" com la que tanto se ha insistido en las últimas décadas.

Recrear la ciudadanía es asumir en primer lugar, nosotros y nosotras, docentes metodistas, una actitud activa $\mathrm{Y}$ comprometida con nuestra realidad y con nuestra comunidad. No podemos enseñar lo que no somos, no podemos transmitir lo que no tenemos, ni compartir no que no hemos experimentado. Recrear la ciudadanía es ser "sal" y ser "luz", como nos pide el Evangelio, para que otros puedan recibir es la luz através de nuestras acciones y palabras. ${ }^{162}$

Já se passaram mais de 300 amos desde o nascimento de John Wesley e hoje, ainda há tanto a aprender com sua história e com a história do povo chamado metodista. Aprender não somente com seus êxitos, mas até mesmo com seus equívocos, inquietações, crises e descaminhos.

Realizar essa pesquisa foi um prazer imensurável! Foi como acender um lampião e caminhar por caminhos não tão usuais. Olhar perspectivas, ouvir outras vozes, buscar o nexo, se surpreender, descobrir, redescobrir, refletir, observar tantos atores diferentes atuando para o mesmo fim! Compreender e procurar ser facilitador para que outros compreendam também.

Percebe-se no âmago deste trabalho a necessidade de que a educação que é realizada através das instituições de ensino da Igreja Metodista esteja preparada para responder aos desafios da atualidade, do novo cenário global, sem perder as marcas de sua história e herança wesleyana, e sem, ao mesmo tempo, tropeçar nos passos da transformação pelo qual o mundo atravessa, na perspectiva de um novo paradigma que se apresenta. Pois utilizando uma visão de mundo obsoleta, ou mecanicista da ciência, haverá um hiato entre o que se deseja e o que se realiza. É

\footnotetext{
${ }^{162}$ Palavras da Professora Adriana B. Murriello, no III Congresso Pedagógico da Associação LatinoAmericana de Instituições Metodistas (ALAIME) - SP, 2004. Ela, Coordenadora do Colégio Ward, em Buenos Aires e Professora Universitária.
} 
salutar que se ratifique que a Igreja Metodista e suas instituições educacionais não têm como paradigma a iluminar seu caminho, nada que não seja o Reino de Deus, segundo o modelo de Jesus Cristo. Assim deverá não somente interpretar a realidade, mas situá-la na perspectiva de uma ação igualmente inovadora do Evangelho.

Vê-se que o tema nos sugere muitas inquietações, reflexões, definições e respostas frente à presença metodista na educação brasileira. Por isso, pode-se considerar esse olhar para trás como um olhar para frente também. Redescobrindo a identidade, buscando os ajustes necessários que os desafios presentes e futuros exigem, buscando a clareza do que fazer com as instituições metodistas de ensino e a educação que produz.

Finalmente, cito Cristovam Buarque:

"Não há futuro sem o profundo gosto pelo sentimento da aventura de construí$10 " .{ }^{163}$

163 Cristovam Buarque em sua obra A aventura da Universidade. São Paulo: Editoras UNIMEP|UNESP. Rio de Janeiro: Paz e Terra, 1994. 


\section{Referência Bibliográfica}

AÇO, G. D. O Histórico do Documento Diretrizes para a Educação na Igreja Metodista in Escola do Futuro. Revista do COGEIME. Conselho Geral das Instituições de Ensino. Ano 2 - Número 2. Piracicaba, 1993, p. 91-100.

ALABY, J. A. Sistema Educacional Metodista: Entre Esperança, Ilusão e Realidade in Escola do Futuro. Revista do COGEIME. Conselho Geral das Instituições de Ensino. Ano 2 - Número 2. Piracicaba, 1993, p. 19-26

ALMEIDA, V. A Educação Escolar Metodista no Nordeste Paulista. Ed. Ribeirão Preto: Colégio Metodista de Ribeirão Preto, 2004.

ARAÚJO, A. A. O. Pontos Notórios na Ação das Instituições Metodistas de Ensino, período de 1945 a 1964 in II Encontro Latino-Americano das Instituições de Metodistas de Ensino. Revista do COGEIME. Conselho Geral das Instituições de Ensino. Ano 4 - Número 7 - 1995, p. 119-124.

BANDEIRA, L. A. M., Presença dos Estados Unidos no Brasil. Rio de Janeiro: Editora Civilização Brasileira, 2007.

BARBOSA, J. C. Encostos ou Cabeças de Pontes. Aspirações de uma Escola Metodista in 300 anos do Nascimento de John Wesley. Revista do COGEIME. Conselho Geral das Instituições de Ensino. Ano 12 - Número 22. Piracicaba, 2003, p. 127-140.

Adoro a Sabedoria de Deus: Itinerário de John Wesley, o Cavaleiro do Senhor. São Bernardo do Campo: EDITEO, 2011.

BASTOS, L. C. Fervorosa Inteligência - Uma Introdução à Teologia Wesleyana. Rio de Janeiro: Corbã Editora Artes Gráficas, p. 27-32, 41-48.

BETTS, D. N. Redesenhando as Organizações de Aprendizagem para o Século XXI in Novas Gerações, Novo Fazer Educacional. Revista do COGEIME. Conselho Geral das Instituições de Ensino. Ano 19 - Número 36. Piracicaba, 2010, p. 39-44. 
BITENCOURT, B. P. Pedagogia e Ética na Educação Metodista in Educação e Cidadania - VII Encontro Nacional Metodista de Educadores, Revista do COGEIME. Conselho Geral das Instituições de Ensino. Ano 5 Número 8. Piracicaba, 1996. p. 147-165.

BOAVENTURA, E. Evolução Histórica do Conceito de Confessionalidade no Metodismo Brasileiro in Identidade e Gestão das Instituições Metodistas de Ensino. Revista do COGEIME. Conselho Geral das Instituições de Ensino. Ano 12, Número23. Piracicaba, 2003, p. 9-23.

BUFFA, E., ARROYO, M. e NOSSELA . Educação e Cidadania: Quem Educa o Cidadão? São Paulo: Cortez, 1987, p. 15.

BUYERS, P. E. Trechos do Diário de John Wesley (tradução). São Paulo: Publicação da Junta Geral de Educação da Igreja Metodista do Brasil, 1965, p. 66.

BURTNER, R. e CHILES, R. Coletânea da Teologia de John Wesley. Rio de Janeiro: Setor de Publicação da Pastoral Bennett, 1995, p. 89.

CAMARGO G. B. Gênio e Espírito do Metodismo Wesleyano. São Bernardo do Campo: Imprensa Metodista, 1986, p. 30-31.

CAPRA, F. O Ponto de Mutação: a Ciência, a Sociedade e a Cultura Emergente. São Paulo: Cultrix, 1997, p. 13.

CARTER, H. The Methodist Heritage. London: Epworth Press, 1951, p. 5355

CESAR, E. E. B. Educação e Confessionalidade in Educação na América Latina. Assembleia da ALAIME. Desafios e Esperanças para o Século XXI. Revista do COGEIME. Conselho Geral das Instituições de Ensino. Ano 6 Número 11, Piracicaba, 1997, p. 7-23.

CHAVES, O. M. Discipulado na Visão de Jesus, Paulo e Wesley. Rio de Janeiro: Editora Chama, 2013, p. 67-70.

COLÉGIO EPISCOPAL. As Marcas de Identidade Metodista. Biblioteca Vida e Missão. São Paulo: Editora Cedro, 2005, p. 9, 33-38.

COKE, T. e MOORE H. The Life of the Rev. John Wesley. London: printed by G. Paramore, 1792, in Editor: Nabu Press. Edição/reimpressão: 2011. p. 54 e 55 
COMÉNIO, J. A. Didática Magna: Tratado da Arte Universal de Ensinar Tudo a Todos. Trad. de Joaquim Ferreira Gomes. 3. Ed. Lisboa: Fundação Calouster Gulbenkian, 1985, p. 139 e 134.

DEWEY, J. Democracia e Educação. Ática, 2007.

DIAS, M. N., Brasil em Perspectiva. São Paulo: Difusão Europeia do Livro, 1968, p.341

DIRETRIZES PARA A EDUCAÇÃO NA IGREJA METODISTA. In Cânones da Igreja Metodista. São Paulo: Colégio Episcopal, 1992, p. 95.

DONATO, R. G. Suzana Wesley e sua Influência na Vida de John Wesley. Muriaé, MG: Edição do Autor, 2012, p. 39, 66, 72.

DORnellas, J. W. Pequena História do Povo Chamado Metodista. Igreja Metodista: Federação de Homens da 1a . Região Eclesiástica, 2002, p. 22-27.

DORNELES, S. S. O Sujeito do Discurso: Uma Leitura de Gênero das Diretrizes para a Educação na Igreja Metodista. RS: Editora Sinodal, 2007, p. 19-26, 44-58.

DUSTAN, J. L. Protestantismo. Rio de Janeiro: Zahar Editores, 1964, p. 132.

ENSLEY, Francis Gerald. João Wesley, o Evangelista. Coleção Metodismo. São Paulo: Imprensa Metodista, 1992, p. 9.

EXPOSITOR CRISTÃO. Periódico Oficial de Comunicação Interna da Igreja Metodista no Brasil. Publicações de: 25-09-1947; 31-05-1945; 09-08-1945; 27-01-1949; 21-08-1958;

FEINER, J. e LOGHRER, M. Compêndio de Dogmática Histórico Salvífica. Petrópolis: VOZES, 1978, p. 50-51.

FITCHETT, W. H. Wesley e Seu Século. Porto Alegre: Carlos Echernique, 1916.5

FRY, P. Para Inglês Ver: Identidade e Política na Cultura Brasileira. Zahar Editores, 1982, p. 37.

FRANKLIN T. N. The Works of John Wesley - Thoughts Upon Slavery in on compact disc. Volume XI: Providence House Publisher, 1995. 
GANDIN, D. Escola e Transformação Social. Petrópolis: Vozes, 1988, p.130.

GREEN, V. H. Religion at Oxfordand Cambridge. London: SCM Press 1964.

GEERTZ, C. A interpretação das Culturas. Rio de Janeiro: Guanabara Koogan, 1989.

HARISON, W. P., Sermões de John Wesley (Tradução Nicodemos Nunes). São Paulo: Imprensa Metodista, 1953.

Heitzenrater, R. P. Wesley: e o Povo Chamado Metodista. São Bernardo do Campo: EDITEO/ Rio de Janeiro: Setor de Publicação Pastoral Bennett, 1996, p. 24.

EDITEO, 2003.

- Santidade e Ignorância Esplêndida. São Bernardo do Campo:

HENDERSON, M. Um Modelo para Fazer Discípulos - A Reunião de Classe de John Wesley. Curitiba, PR: Ministério Igreja em Células, 2012, p. 169,170 .

HINSOR, W. J. A Dinâmica do Pensamento de Wesley. São Bernardo do Campo: Imprensa Metodista, p. 11 e 12.

HOBSON, J. A. Imperialism, a Study. Charles River Editors, 2011.

JOURNAL CHRISTAN ADVOCATE. New York: T. Carlton e J. Porter, 14.09.1899.

JOY, J. R. O Despertamento Religioso de John Wesley. Rio de Janeiro: Setor de Publicação da Pastoral Bennett, 1996, p. 37-46.

KLAIBER, Walter e MARQUARDT Manfred. Viver a Graça de Deus: um Compêndio da Teologia Metodista. São Bernardo: EDITEO, 1999, p. 81.

LEONARD, H. G. O Protestantismo Brasileiro. São Paulo: Editora JUERP e ASTE. 1981, p. 30-45.

LUCCOCK, H. E. Linha de Esplendor sem Fim. Rio de Janeiro: Editora Bennett, 2a . Edição Revista e Atualizada, 2001, p. 79, 80.

LUNN, A. John Wesley. Toronto, Canadá: The Dial Press, 1929. 
MANTOAN, M. T. E. - Laboratório de Estudo e Pesquisa em Ensino e Diversidade da Universidade Estadual de Campinas. p. 28.

MASER, F. E. The Story of John Wesley`s Sisters. Rutland, VT: Academy Books, 1988.

MATEO, L. Juan Wesley, Su Vida y Obra. Nashvill: Smith y Lamar, 1911.

MATOS, H. C. J. Nossa História - 500 Anos de Presença da Igreja Católica no Brasil - Tomo 1: Período Colonial. São Paulo: Editora Paulinas, 2011, p. 97-158.

MATTOS, P. A. Mais de um Século de Educação Metodista: Tentativa de um Sumário Histórico-Teológico de uma Aventura Educacional. Piracicaba: Terra Comunicação, 2000, p.28, 59.

MENDONÇA, A. G. Educação, Confessionalidade e Ecumenicidade: A Questão da Fé e da Cultura in Panorama da Educação Metodista na Brasil: Uma atualização de Sistema Educacional Metodista. Revista do COGEIME. Conselho Geral das Instituições de Ensino. Ano 4 - Número 7. Piracicaba, 1995, p. 147-155.

Meneghetti, R. G. K. A Proposta Educacional Metodista no Brasil. Revista Comunicações, Piracicaba, Ano 5. Número 2, p. 151-166, Nov. 1998, p.153.

MESQUIDA, P. Metodismo e Educação no Brasil: Formar Elites e Civilizar a Nação in Escola do Futuro. Revista do COGEIME. Conselho Geral das Instituições de Ensino. Ano 2 - Número 2. Piracicaba, 1993, p. 2950 .

MURIELlO, A. B. Recrear la Ciudadanía: un Desafío para la Formación Docente in Formação Docente, Revista do COGEIME. Conselho Geral das Instituições de Ensino. Ano 14, Número 26, Piracicaba, 2005.

NASCIMENTO, A. John Wesley, o Iluminismo e a Educação Metodista na Inglaterra in 300 anos do Nascimento de John Wesley. Revista do COGEIME. Conselho Geral das Instituições de Ensino. Ano 12 - Número 22. Piracicaba, 2003, p. 89-104.

NEIBUHR, R. A. As origens Sociais das Denominações Cristãs. São Paulo: Editora ASTE, 1992, p. 47. 
NICHOLS, R. História da Igreja Cristã. São Paulo: Casa Editora Presbiteriana, 1954, p. 139.

NOVAES, J. L. C. Escola, Liberalismo e Educação Metodista no Brasil. in 300 anos do Nascimento de John Wesley. Revista do COGEIME. Conselho Geral das Instituições de Ensino. Ano 12 - Número 22. Piracicaba, 2003, p. 105-126.

NOVAIS F. e MOTA, C. G. A Independência Política do Brasil. São Paulo: Hucitec, 1996.

OLIVEIRA, A. M. e TIMM E. Z., Teorizando um Pensamento para a Educação Metodista in Educação para a Paz. Assembleia da ALAIME. Desafios e Esperanças para o Século XXI. Revista do COGEIME. Conselho Geral das Instituições de Ensino. Ano 14 - Número 27. Piracicaba, 2005. p. 75-86.

OLIVEIRA, C. T. Dimensões Teológicas da Educação Metodista in Encontro Nacional de Pastorais Escolares e Universitárias das Instituições Metodistas de Educação, 1992, Porto Alegre. Texto não publicado.

Aspectos da Filosofia Educacional de John Wesley in 300 anos do Nascimento de John Wesley. A Revista do COGEIME. Conselho Geral das Instituições de Ensino. Ano 12, Número 22, Piracicaba, 2003, p. 69-88.

A Trajetória da Educação Metodista - PVMI e DEIM: 20 anos de História in Revista do COGEIME. Conselho Geral das Instituições de Ensino. Ano 12, Número 23, Piracicaba, 2003.

OLIVEIRA, C. T., REILY, D. A., SILVA, G. J., SOUZA, J. C., SALVADOR, J. G. Situações Missionárias na História do Metodismo. São Paulo: Imprensa Metodista e EDITEO, p. 17-30, 31-40.

OLMSTEAD C. E. History of Religion in the United States. Englewood Cliffs, NJ: Prentice-Hall, 1960.

OUTLER, A. C. John Wesley. New York: Oxford University Press, 1964.

Sermões de Wesley. Vol II, in The Bicentennial Edition of the Works of John Wesley. Editor in Chief, Frank Baker. Nashville: Abingdon Press, 1985, p. 509-510.

PANTELIS, J. A Escola Metodista in Educação na América Latina. Assembleia da ALAIME. Desafios e Esperanças para o Século XXI. Revista 
do COGEIME. Conselho Geral das Instituições de Ensino. Ano 6 - Número 11, Piracicaba, 1997, p. 65-68.

RAMAlHO, J. P. Prática Educativa e Sociedade: Um Estudo de Sociologia da Educação, Rio de Janeiro: Editora Zahar, 1976, p. 69.

RAMOS, L. C. A Prática Homilética de John Wesley in CAMINHANDO Revista da Faculdade de Teologia da Igreja Metodista. Ano IX, Número 3, São Bernardo do Campo, 2004, p. 133-152.

REILY, Ducan Alexander . A Influência do Metodismo: Revolução Social na Inglaterra do Século XVIII. Publicação da Junta Geral de Ação Social da Igreja Metodista do Brasil, 1953.

Metodismo Brasileiro e Wesleyano. São Bernardo do Campo: Imprensa Metodista, 1981, p. 164, 202.

História documental do Protestantismo no Brasil. São Paulo: ASTE. 1984, p. 102

RENDERS, H. A Memória de John Wesley: "Mergulho Social", "Participação Cultural" e Confessionalidade in 300 anos do Nascimento de John Wesley. A Revista do COGEIME. Conselho Geral das Instituições de Ensino. Ano 12 - Número 22. Piracicaba, 2003, p. 47-56.

Quando a Guerra começa, Deus é esquecido. John Wesley sobre a guerra in Revista Mosaico Apoio Pastoral, São Bernardo do Campo: FATEO. Ano 11 - Número 28, 2003, p. 18-19.

Papel Social e Subjetivação do Metodismo Nascente, in Revista Caminhando - Ano IX. Faculdade de Teologia da Igreja Metodista, 2004.

(org.). Sal da Terra e Luz do Mundo - 100 anos do Credo Social da Igreja Metodista. EDITEO - Editora da Faculdade de Teologia, São Bernardo do Campo, SP, 2009, p. 47-50.

REVISTA CAMINHANDO. Wesley e os Encontros com Grupos Pequenos. Ano VII, Número 10.2, São Bernardo do Campo: EDITEO. 2001.

Pequenos Grupos na Tradição Metodista. Ano VIII, Número 12.2, 2003 São Bernardo do Campo: EDITEO. 2003, p. 68-95.

REVISTA CHRISTIAN HISTORY. Os Irmãos Wesley. Edição 69. Volume XX, Número 1, 2002, p. 9, 12-21, 26-37. 
A Revista do COGEIME. Conselho Geral das Instituições de Ensino. A Trajetória da Educação Metodista PVMI e DEIM: 20 Anos de História. Ano 12, Número 23. Piracicaba, 2003. p. 15.

Perspectivas da Educação Brasileira e a LDB. VIII Encontro Nacional Metodista de Educação. Ano 7, Número 12 - 1998.

Tendências Atuais da Educação e as Instituições Metodistas de Ensino. Ano 5, Número 9 . Piracicaba, 1996.

REVISTA EM MARCHA. Estudos Doutrinários do Metodismo. Vol II. São Bernardo do Campo: Imprensa Metodista. p. 22.

REVISTA NOVA ESCOLA - Edição Especial - número 11: Editora Abril, p. 11.

REVISTA FÉ E NEXO. Dia do Metodismo. Material Suplementar do Jornal Avante, Publicação Oficial da Igreja Metodista na Primeira Região Eclesiástica - Rio de Janeiro. Número 28, 2010, p. 10-13.

RIBEIRO, C de O., RENDERS H., SOUZA J. C. e JOSGRILBERG R. S. (Orgs). Teologia e Prática na Tradição Wesleyana: Uma Leitura a Partir da América Latina. São Bernado: EDITEO, 2005.

RIBEIRO, D. O Povo Brasileiro - A Formação e o Sentido do Brasil. São Paulo: Companhia da Letras, 1995, p. 45-56.

ROCHA, I. Histórias da História do Metodismo no Brasil. São Paulo: Imprensa Metodista, 1967, p. 44-48, 129,130.

ROMAnElli, O. de O. História da Educação no Brasil. Período da Segunda República. O Manifesto dos Pioneiros da Educação Nova: 1932. São Paulo: Editora Vozes. Edição 34, 2012.

RUNYON, T. A Nova Criação: a Teologia de Wesley Hoje. São Bernardo do Campo: EDITEO \SBC, 2002, p. 35.

SALVADOR, J. G. História do Metodismo no Brasil. Imprensa Metodista. São Bernardo do Campo, 1982.

SANTOS, L. de A. Entre a Utopia e o Labirinto - Democracia e Autoritarismo no Pensamento Educacional Brasileiro nos anos 1980. Rio de Janeiro: Ed. Quaret - APERJ, 2011, p. 27, 29, 36. 
SOUZA, J.C. O Metodismo Norte-americano no Início do Século XX: A Missão como Testemunho Social. São Bernardo do Campo: Imprensa Metodista, 1991, p. 37.

SEVERINO, A. J. O Público e o Privado em Categoria de Análise de Educação. Campinas: HISTEDBR/UNISAL, 2005, p.32.

SILVA, R. C. A Educação e as Constituições: da Primeira República ao Governo Revolucionário in Escola do Futuro. Revista do COGEIME. Conselho Geral das Instituições de Ensino. Ano 2 - Número 2. Piracicaba, 1993, p. 83-89.

STRECK, D. R. Correntes pedagógicas: Aproximações com a Teologia. Petrópolis: Vozes, 1994, p. 26.

TEIXEIRA, U. Teologia e História do Metodismo - Uma Reflexão Latino Americana. Kirios Gráfica Editora Ltda. Rio de Janeiro, 2010, p. 58-68.

TOURINE, A. Crítica da Modernidade. São Paulo: Vozes, 1995.

WESLEY, J. The Letters oh John Wesley in Londom: The Epworth Press, 1931.

\footnotetext{
_ Sermões. (tradução) in: São Paulo: Imprensa Metodista, Vols. I e II, 1954.
}

Explanatory Notes Upon the New Testament in Alec R. Allenson, INC, Naperville III, 1958.

The Journal. London: The Epworth Press, vols. III, IV, V, VI, VII, in: HEITZENRATER, R.P.The Work's of John Wesley. The Bicentennial Edition. Editado por HEITZENRATER R.P. Nashiville. Abigdon Press, 1960. 1872 .

Obras. Zondervan: Grand Rapids, Mich, vols. VIII, IX, X, XI, XII,

Sermões. O Despertar do Pecador (tradução de Ducan A. Reily). Vol. I , in São Paulo: Imprensa Metodista, 1984, p. 22 e 23, 35, 37.

WILliAMS, C. La Teologia de Juan Wesley. Costa Rica: Ediciones SEBILA, 1989, p. 24. 


\section{Anexo 1}

\section{DEIM}

\section{Diretrizes para a Educação na Igreja Metodista}

\section{Prefácio Histórico}

$\mathrm{Na}$ continuidade de um processo iniciado há longo tempo e de projetos elaborados anteriormente, e tentando responder a anseios já existentes, a Igreja Metodista iniciou, em 1979, um processo formal para definir posições que servissem como diretrizes para a tarefa educativa de suas escolas. Após pesquisas em igrejas e instituições metodistas no País, realizou-se um seminário no Rio de Janeiro, em julho de 1980, convocado pelo Conselho Geral, quando se elaborou um documento intitulado Fundamentos, Diretrizes e Objetivos para o Sistema Educacional Metodista. Este documento, voltado para as instituições de ensino secular e teológico, foi publicado pelo Expositor Cristão e encaminhado a várias igrejas, instituições e órgãos regionais e gerais, para que fosse avaliado.

Enquanto se desenrolava esse processo, a Secretaria Executiva de Educação Cristã do Conselho Geral promovia, a mando deste, a busca de um posicionamento acerca da Educação Cristã. Certas afirmações básicas, intituladas A Educação Cristã: um posicionamento metodista, foram também publicadas e propostas à Igreja em 1981. Por outro lado, tendo em vista a necessidade de preparação do Plano Para a Vida e a Missão da Igreja, o Conselho Geral procurou também definir a maneira metodista de se entender a vida e a missão da Igreja. Isso foi levado a efeito por meio de pesquisa da Igreja e, especialmente, por meio de uma Consulta Sobre Vida e Missão. Um documento sobre essa compreensão foi também elaborado e publicado no órgão oficial da Igreja. Tendo em vista as colocações alcançadas, o Conselho Geral determinou que elas fossem consideradas quando da revisão final dos Fundamentos, Diretrizes, Políticas e Objetivos para o Sistema Educacional Metodista. Esses deveriam ser ampliados, de modo a incluir também as responsabilidades da Igreja no campo de Educação Cristã. Com essa finalidade, em janeiro de 1982 reuniu-se o Seminário Diretrizes para um Plano Nacional de Educação, no Instituto Metodista de Ensino Superior. Foram convocados os bispos, os membros do Conselho Geral, representantes dos Conselhos Regionais, das Federações Regionais de Homens, Senhoras, Jovens e Juvenis, bem como das respectivas Confederações. Cada instituição de ensino (secular e teológico) foi convidada a enviar dois representantes. Os 
alunos de cada instituição de ensino teológico também foram convidados a enviar um representante.

O Seminário pretendia elaborar um posicionamento que levasse em conta, além das propostas dos documentos acima citados, a análise do opinamento recebido das igrejas, órgãos e instituições. A complexidade da matéria mostrou que não se alcançaria a redação apropriada. Uma comissão foi então eleita pelo Seminário e encarregada de reunir essas conclusões, aproveitando também os estudos ali realizados. O documento Diretrizes para a Educação na Igreja Metodista é o resultado do trabalho, aprovado pelo Conselho Geral e sancionado pelo XIII Concílio Geral da Igreja Metodista.

\section{I - O que estamos vendo}

A Educação tem sido um dos instrumentos sempre presentes na ação da Igreja Metodista no Brasil. Como instrumento de transformação social, ela é parte essencial do envolvimento da Igreja no processo da implantação do Reino de Deus.

A ação educativa da Igreja acontece de diversas maneiras: por meio da família, da igreja local em todas as suas agências (comissões, Escola Dominical, o púlpito, os grupos societários, etc.), das suas instituições de ensino secular, teológico, de ação comunitária e de comunicação.

Levando em conta o Evangelho e sua influência sobre todos os aspectos da vida, a ação educativa metodista trouxe muitas contribuições positivas. Especialmente, por meio da igreja local, muitas pessoas foram convertidas e transformadas, modificando suas vidas e seu modo de agir. Por intermédio das instituições, a Igreja buscou a democratização e a liberalização da educação brasileira. Suas propostas educacionais eram inovadoras e humanizantes, pois ofereciam um tipo de educação alternativa aos rígidos sistemas jesuíta e governamental.

A ação educativa da Igreja, entretanto, deu muito mais valor às atitudes individualistas em relação à sociedade. $O$ mais importante era uma participação pessoal e isolada. No caso específico das nossas escolas, à medida em que a sociedade brasileira foi se desenvolvendo, elas perderam suas características inovadoras e passaram a ser reprodutoras da educação oficial. Esvaziaram-se, perdendo sua percepção de que o Evangelho tem também dimensões políticas e sociais, esquecendo, assim, sua herança metodista. Em razão de suas limitações históricas e culturais, a ação educativa metodista tornou-se prejudicada em dois pontos importantes: primeiro, porque não se identificou plenamente com a cultura brasileira; segundo, por ter apresentado pouca preocupação em descobrir soluções em profundidade para os problemas dos pobres e desvalidos, que são a maioria do nosso povo.

Hoje, no Brasil, vivemos situações que exigem de nós resposta concreta. Os problemas que afligem nosso povo, desde a família até os aspectos mais amplos da vida nacional, colocam um grande desafio e todos precisamos contribuir para encontrar as soluções que atendam aos verdadeiros interesses 
da maioria da nossa população. Percebemos que muitas são as forças contrárias à vida. Mas também acreditamos que o Evangelho nos capacita a encontrar aquelas soluções que possibilitam a realização dos verdadeiros interesses do povo brasileiro. Por isso, nós, metodistas, à luz da Palavra de Deus, examinamos nossa ação educativa presente, dispondo-nos a buscar novas linhas para essa ação.

\section{II - O que nos diz a Bíblia}

O Deus da Bíblia - que é Pai, Filho e Espírito Santo - se revela na história humana como Criador, Senhor, Redentor, Reconciliador e Fortalecedor. Esse Deus Trino, em seu relacionamento com o Ser Humano, cria uma nova comunidade, sinalizada historicamente por meio da vida do povo de Israel e da Igreja. A ação divina sempre nos aponta para a realização plena do Reino de Deus.

A esperança deste Reino é vivida e experimentada parcialmente na vida do povo de Deus, na promessa a Abraão (Gn 12.1-4; 13.14-17; 17.8-9; 22.1518), na experiência do êxodo (Êx 3.7-8; 6.1-9; 13.21-22; 14.15-16; 15.26; 16.4; Dt.7.6-8), na conquista da terra (Js 1.1-9;13-15; 24.14-25; Lv 25.855), na pregação dos profetas (Is 49.8-26; 55.1-13; Ez 36.22-37; Jl 2.12-32, Mq 2.12-13; 4.1-13), e em outras formas. Essa esperança foi manifestada de maneira completa na vida de Jesus de Nazaré (Mc 1.15; Mt 6.9-13; Lc 4.1621; Mc 14.23-25; I Co 11.23-26). Por meio da vitória de Jesus Cristo sobre o pecado e a morte, temos a certeza de que se completará a realização total do Reino de Deus (Mt 28.1-10; I Co 15.50-58; Ap. 21.1-8).

A ação de Deus se realiza por meio do Espírito Santo (Jo 16.7-14). O dom do Espírito é a força e o poder que faz brotar entre nós os sinais do Reino de Deus e sua justiça, da nova criação, do novo homem, da nova mulher, da nova sociedade (II Co 5.5, 14-17). O Espírito nos revela que o Reino de Deus é maior que qualquer instituição ou projeto humano (Mt 12.1-8).

Toda a nossa prática deve estar de acordo com o Reino de Deus (Mt 6.33; Jo 14.26) e o Espírito Santo é quem nos mostra se essa concordância existe ou não. O Espírito de Deus age onde, como e quando quer (Jo 3.5-8) a fim de criar as condições para o estabelecimento do Reino. Só quando compreendemos isso é que nos comprometemos com o projeto de Deus. Então percebemos claramente que Deus quer dar ao ser humano uma nova vida, à imagem de Jesus Cristo, pela ação e poder do Espírito Santo. Por isso, Ele condena o pecado individual e social, gerador das forças que impedem as pessoas e os grupos de viver plenamente.

Sendo assim, a salvação é entendida como resultado da ação de Deus na História e na vida das pessoas e dos povos. Biblicamente, ela não se limita à idéia da salvação da alma, mas inclui a ação de Deus na realidade de cada povo e de cada indivíduo. Isso atinge todos os aspectos da vida: religião, trabalho, família, vizinhança, meios de comunicação, escola, política, lazer, economia (inclusive meios de produção), cultura, segurança e outros. A salvação é o processo pelo qual somos libertados por Jesus Cristo para servir a Deus e ao próximo e para participar da vida plena no Reino de Deus. 
A revelação do Reino de Deus em Jesus Cristo é motivo de esperança para todos nós ( $\mathrm{Rm}$ 8.20-25). O Reino se realiza parcialmente na história (Mt 12.28) por meio de sinais que apontam para a plenitude futura. Ele é o modelo permanente para a ação do povo de Deus (Mt 20.24-28) criando em nós consciência crítica (I Co 2.14-16), capaz de desmascarar todos os sistemas de pensamento que se julgam donos exclusivos da verdade. A esperança no Reino permite que participemos de projetos históricos que visam à libertação da sociedade e do ser humano. Ao mesmo tempo, nos liberta da idéia de que os projetos humanos são auto-suficientes e nos leva a qualquer atitude de endeusamento de instituições.

A ação de Deus atinge, transforma e promove as pessoas, na medida em que as desafia a um relacionamento pleno e libertador com Deus e o próximo, para o serviço concreto na comunidade. A natureza do Reino exige compromisso do novo homem e da nova mulher e sua sociedade, na direção da vida abundante da justiça e liberdade oferecidas por Cristo. Deus se manifesta sempre em atos de amor, pois ele é amor (I Jo 4.7-8) e quer alcançar a toda a criação, pois nada foge à graça divina. Em Cristo, Deus nos ama de tal maneira que dá sua vida por todos, alcançando especialmente os pobres, os oprimidos e marginalizados dos quais assume a defesa com justiça e amor. Seu amor quebra as cadeias da opressão, do pecado, em todas as suas formas. Por seu amor, ele nos liberta do egoísmo para uma vida de comunidade em amor e serviço ao próximo.

O Reino de Deus alcança qualquer tipo de pessoa, quaisquer que sejam suas ideias, suas condições sociais, culturais, políticas, econômicas ou religiosas. Alcança igualmente a pessoa como um todo: corpo, mente e espírito, com todas as suas exigências. Os atos de Deus, pelos quais ele revela e inaugura o seu Reino, nos ensinam também como devemos agir, e são o critério para a ação missionária da Igreja.

\section{III - Algumas considerações das quais devemos lembrar}

Toda a ação educativa se baseia numa filosofia, isto é, numa visão a respeito do mundo e das pessoas. Em nosso caso, a filosofia é iluminada pela fé, estando por isso sempre relacionada com a reflexão teológica, à luz da revelação bíblica, em confronto com a realidade.

Até o momento, nossa ação educativa tem sido influenciada por ideias da chamada filosofia liberal, típicas de nossa sociedade, resultando num tipo de educação com características acentuadamente individualistas.

Alguns dos elementos fundamentais dessa corrente, são:

- preocupação individualista com a ascensão social;

- acentuação do espírito de competição;

- aceitação do utilitarismo como norma de vida;

- colocação do lucro como base das relações econômicas.

Nenhum desses elementos está de acordo com as bases bíblico-teológicas sobre as quais se deve fundamentar a prática educativa metodista. 
A Educação, na perspectiva cristã, "como parte da Missão, é o processo que visa a oferecer à pessoa e comunidade uma compreensão da vida e da sociedade, comprometida com uma prática libertadora, recriando a vida e a sociedade, segundo o modelo de Jesus Cristo, e questionando os sistemas de dominações e morte, à luz do Reino de Deus"(Plano Para a Vida e a Missão da Igreja Metodista). Por isso, a Igreja precisou definir novas diretrizes educacionais, voltadas para a libertação das pessoas e da sociedade.

A partir dessas diretrizes, a Igreja desenvolverá sua prática educativa, de tal modo que os indivíduos e os grupos:

- desenvolvam consciência crítica da realidade;

- compreendam que o interesse social é mais importante que o individual;

- exercitem o senso e a prática da justiça e solidariedade;

- alcancem a sua realização como fruto do esforço comum;

- tomem consciência de que todos têm direito de participar de modo justo dos frutos do trabalho;

- reconheçam que, dentro de uma perspectiva cristã, útil é aquilo que tem valor social.

\section{IV - O que devemos fazer}

A ação educativa da Igreja tem que estar mais firmemente ligada aos objetivos da Missão de Deus, visando à implantação do seu Reino. Além disso, nossos esforços educacionais de todo tipo têm também que se identificar mais com a cultura brasileira e atender às principais necessidades do nosso povo. Por isso, é preciso que busquemos novos caminhos.

A busca desses novos caminhos deve procurar a superação do modelo educacional vigente. Não se pode mais aceitar uma educação elitista, que discrimina e reproduz a situação atual do povo brasileiro, impedindo transformações substanciais em nossa sociedade. Também não podemos nos conformar com a tendência que favorece a imposição da cultura dos poderosos, impedindo a maior participação das pessoas e aumentando cada vez mais seu nível de dependência.

Uma tomada de decisão nesse sentido não deve ser entendida como simples reação às falhas que encontramos na ação educativa, mas como uma atitude necessária de uma Igreja que deseja ser serva fiel, participando ativamente na construção do Reino de Deus.

A partir dessas constatações, declaramos que a ação educativa da Igreja Metodista - realizada por todas as suas agências, isto é, a Escola Dominical, comissões, púlpito, grupos societários, instituições de ensino secular, teológico, de ação comunitária, etc. - terá por objetivos:

1 - Dar continuidade, sob a ação do Espírito Santo, ao processo educativo realizado por Deus em Cristo, que promove a transformação da pessoa em nova criatura e do mundo em novo mundo, na perspectiva do Reino de Deus; 2 - Motivar educadores e educandos a se tornarem agentes positivos de libertação, com uma prática educativa de acordo com o Evangelho; 
3 - Confrontar permanentemente as filosofias vigentes com o Evangelho; 4 - Denunciar todo e qualquer tipo de discriminação ou dominação que marginalize a pessoa humana e anunciar a libertação em Jesus Cristo; 5 - Respeitar e valorizar a cultura dos participantes do processo educativo, na medida em que estejam de acordo com os valores do Reino de Deus; 6 - Apoiar os movimentos que visem à libertação dos oprimidos dentro do espírito do Evangelho libertador de Jesus Cristo; 7 - Despertar consciência crítica e sensibilizada para o problema da justiça, num mundo marcado pela opressão.

Com base nesses posicionamentos, ficam estabelecidas as seguintes diretrizes gerais:

1 - Toda e qualquer iniciativa educacional da Igreja, especialmente a organização de novos cursos e projetos, levará sempre em consideração os objetivos da Missão, de acordo com os documentos oficiais da Igreja e as necessidades locais;

2 - Quanto aos cursos, currículos e programas já existentes, as agências da Igreja se empenharão para que, no menor prazo possível, estejam de acordo com as orientações estabelecidas neste documento;

3 - Será buscado um estreito relacionamento com as comunidades em que nossos trabalhos estão localizados, compartilhando com elas os seus problemas;

4 - Em todos os lugares em que a Igreja atua serão colocadas à disposição da comunidade, das organizações de classe e das entidades comunitárias, as instalações de que dispomos, tanto para a realização de programas, quanto para a discussão de temas de interesse comunitário, de acordo com os objetivos da Missão;

5 - As igrejas e instituições devem atuar também por meio de programas de educação popular, para isso, destinando recursos financeiros específicos;

6 - Toda a ação educativa da Igreja deverá proporcionar aos participantes condições para que se libertem das injustiças e males sociais que se manifestam na organização da sociedade, tais como: a deterioração das relações na família e entre as pessoas, a deturpação do sexo, o problema dos menores, dos idosos, dos marginalizados, a opressão da mulher, a prostituição, o racismo, a violência, o êxodo rural resultante do mau uso da terra e da exploração dos trabalhadores do campo, a usurpação dos direitos do índio, o problema da ocupação desumanizante do solo urbano e rural, o problema dos toxicômanos, dos alcoólatras, e outros;

7 - A educação da criança deverá merecer especial atenção, notadamente na faixa do pré-escolar (de 0 a 6 anos), e de preferência voltada para os setores mais pobres da população; 
8 - Visando à unidade educacional da Igreja em sua missão, as igrejas locais e instituições se esforçarão no sentido de uma ação conjunta em seus projetos educacionais;

9 - A Igreja e suas instituições estabelecerão programas destinados à formação de pessoas capacitadas para todas as tarefas ligadas à ação educacional e social;

10 - Todas as agências de educação da Igreja Metodista, tanto igreja local quanto instituição procurarão orientar os participantes de seu trabalho sobre as diretrizes ora adotadas, empenhando-se igualmente para que elas sejam vividas na prática.

\section{A - No caso específico da Educação Secular:}

A Igreja entende a Educação Secular que promove como o "processo que oferece formação melhor qualificada nas suas diversas fases, possibilitando às pessoas o desenvolvimento de uma consciência crítica e seu comprometimento com a transformação da sociedade, segundo a missão de Jesus Cristo"( Plano Para a Vida e a Missão da Igreja). Por isso:

1 - O ensino formal praticado em nossas instituições não se limitará a preparar para o mercado de trabalho, mas, além disso, igualmente, deverá despertar uma percepção crítica dos problemas da sociedade.

2 - As instituições superarão a simples transmissão repetitiva de conhecimentos, buscando a criação de novas expressões do saber, a partir da realidade e expectativa do povo.

3 - Terá prioridade a existência de pastorais escolares que atuem como consciência crítica das instituições, em todos os seus aspectos, exercendo suas funções profética e sacerdotal dentro e fora delas.

4 - Toda a prática das instituições se caracterizará por um contínuo aperfeiçoamento no sentido de democratizar cada vez mais as decisões.

5 - Os órgãos competentes farão com que essas diretrizes sejam cumpridas em suas instituições.

6 - As instituições participarão em projetos da Igreja compatíveis com suas finalidades estatutárias, atendendo aos fins da Missão.

\section{B - No caso específico da Educação Teológica}

1 - "A Educação Teológica é o processo que visa à compreensão da história em confronto com a realidade do Reino de Deus, à luz da Bíblia, e da tradição cristã reconhecida e aceita pelo metodismo histórico como instrumentos de reflexão e ação para capacitar o povo de Deus, leigos e clérigos, para a vida e missão, numa dimensão profética". (Plano para a Vida e a Missão da Igreja).

2 - Os currículos serão fundamentados nas bases teológicas reconhecidas pela 
Igreja Metodista, como identificadas no presente documento, com vistas a mudanças na metodologia do trabalho teológico, a partir das necessidades do povo.

3 - No recrutamento e seleção dos professores de Teologia se observará não apenas a sua adequada qualificação aos cursos a serem ministrados mas também, a sua vivência pastoral e a consciência que tenham de que a tarefa teológica deve ser feita a partir da revelação, no contexto do povo brasileiro e tendo em vista o atendimento de suas necessidades.

4 - O processo de recrutamento dos que aspiram ao pastorado, incluirá, sistematicamente, um programa pré-teológico de estudos, que os iniciará no processo de reflexão sobre as preocupações da Igreja, como definidas nos seus documentos.

5 - A Educação Teológica será desenvolvida observando-se os seguintes relacionamentos:

- Relacionamento com o contexto social: a metodologia do trabalho teológico, em todos os níveis, terá relação direta com a realidade da sociedade brasileira, na perspectiva do oprimido, visando ao processo de sua libertação. - Relacionamento com outras áreas do conhecimento humano: o trabalho teológico deverá ser desenvolvido de uma forma integrada a outras áreas do conhecimento, incluindo tanto as ciências humanas como as áreas de tecnologia, de ciências exatas, de saúde, ciências aplicadas e outras. - Relacionamento entre as instituições de ensino: o trabalho teológico deverá ser realizado de maneira integrada, de tal modo que todo o ensino teológico na Igreja promova a sua unidade de pensamento e ação naquilo que seja fundamental.

- Relacionamento ecumênico: a Educação Teológica será enriquecida pelo contato com outras Igrejas cristãs, inclusive de outros países.

6 - As instituições de ensino teológico oferecerão cursos de formação e atualização teológica para pastores/as e leigos/as, com a finalidade de os ajudar a reexaminar continuamente seu ministério e serviço, desde a perspectiva do Reino de Deus.

7 - As instituições de ensino teológico desenvolverão esforços na pesquisa junto à igreja local e outras fontes para a renovação litúrgica, levando em conta as características culturais do povo brasileiro.

8 - Os órgãos competentes estudarão uma maneira de uniformizar o tratamento dos seminaristas, pelas regiões eclesiásticas, em termos de ajuda financeira (bolsas), apoio e requisitos dos estudantes para ingresso e continuação dos estudos na Faculdade de Teologia e Seminários.

\section{C - No caso específico de Educação Cristã:}

1 - "A Educação Cristã é um processo dinâmico para transformação, libertação e capacitação da pessoa e da comunidade. Ela se dá na caminhada da fé e se desenvolve no confronto da realidade histórica com o Reino de Deus, num 
comprometimento com a Missão de Deus no mundo, sob a ação do Espírito Santo, que revela Jesus Cristo, segundo as Escrituras" (Plano para a Vida e a Missão da Igreja).

2 - O currículo de Educação Cristã na Escola Dominical será fundamentado na Bíblia e tratará de relacionar os relatos bíblicos com a realidade na qual a Igreja se encontra.

3 - As secretarias executivas regionais de Educação Cristã estabelecerão cursos e programas, com vistas à formação e aperfeiçoamento dos obreiros da Escola Dominical, para que desenvolvam uma metodologia de ensino compatível com as diretrizes contidas neste documento.

4 - A Igreja retomará especial cuidado para com a criança e o adolescente, redefinindo a organização destes grupos e provendo material educativo adequado para essas idades.

5 - Os grupos societários desenvolverão estudos e programas que auxiliem os seus participantes a compreender e viver a ação libertadora do Evangelho e serão municiados pela Igreja com literatura e sugestões apropriadas para alcançar este objetivo.

6 - Tendo em vista o fato de que a liturgia é um processo educativo, os/as pastores/as e obreiros/as leigos/as serão incentivados a descobrir novas formas litúrgicas que promovam a educação do povo de Deus.

7 - O Conselho Geral estabelecerá programas mínimos de educação religiosa para as instituições metodistas de ensino secular, em todos os níveis, levando em conta as diretrizes aqui estabelecidas.

8 - O Conselho Geral providenciará programas mínimos de educação religiosa a serem desenvolvidos, quando isto for possível, em escolas públicas.

9 - O Conselho Geral providenciará material educativo a ser utilizado na igreja local e capacitação do catecúmeno, novo convertido, pais e testemunhas quanto ao batismo e noivos, quanto ao casamento.

10- O Conselho Geral providenciará material educativo a ser utilizado na igreja local visando a conscientizar a família acerca de seu papel à luz da Missão.

Parágrafo único - As instituições educacionais da Igreja, de qualquer nível e grau, são regidas pelas Diretrizes para a Educação da Igreja Metodista, devendo toda a sua vida administrativa e acadêmica ser planejada e desenvolvida segundo seus ditames. 


\section{Anexo 2}

\section{Regulamento das Pastorais Escolares e Universitárias}

\section{- ESTRUTURA, COMPETÊNCIA E FUNCIONAMENTO -}

\section{Introdução}

O Colégio Episcopal da Igreja Metodista, no uso de suas atribuições (Cânones, Art. 63, item XVII) define por este regulamento a estrutura, competência e funcionamento das Pastorais Escolares e Universitárias, que são uma das expressões da vida e missão da Igreja e da marca da confessionalidade que caracteriza as Instituições Metodistas de Educação. A proposta de trabalho da Pastoral está fundada e fundamentada nos documentos oficiais da Igreja Metodista ${ }^{164}$. À luz destes documentos se estabelece sua ação pastoral.

\section{A PASTORAL, SUA MISSÃO E SEU PROPÓSITO EVANGELIZADOR}

Art. 1 - De acordo com as Diretrizes para a Educação na Igreja Metodista, a missão da Pastoral é "atuar como consciência crítica das instituições de ensino, em todos os seus aspectos, exercendo suas funções proféticas e sacerdotais, dentro e fora delas" (DEIM, inciso IV, alínea A, item 3).

Art. 2 - É sua tarefa, ao lado dos demais representantes da Igreja:

I - Fomentar a consciência crítica em todas as áreas da vida institucional;

II- Fortalecer todas as ações que despertem o sentido da confessionalidade metodista;

III - Participar da vida da instituição em suas diferentes dimensões,especialmente na área de avaliação institucional e nos órgãos superiores de decisão, pautada pela dimensão ética do Evangelho.

\footnotetext{
${ }^{164}$ Lei Ordinária da Igreja Metodista constante dos Cânones, Plano Para a Vida e a Missão da Igreja, Diretrizes para a Educação na Igreja Metodista, Pastorais do Colégio Episcopal e demais documentos oficiais da Igreja Metodista.
} 


\section{Objetivos da Pastoral}

Art.3ํ - A Pastoral confessa, à luz da revelação bíblica e do metodismo histórico, na perspectiva de uma Igreja de dons e mistérios, que se percebe como "comunidade missionária a serviço do povo", que o projeto do Reino de Deus visa a construção da dignidade da vida.

Afirma que as Instituições Metodistas de Educação são confessionais como um todo,cabendo à Pastoral, fomentar a consciência crítica, profética, sacerdotal e pastoral narealização deste ministério. A partir destes princípios, busca estimular e apoiar ainstituição na implantação e manutenção de uma espiritualidade que possibilite avivencia do Evangelho em sua plenitude. Para isso deve desenvolver os seguintes objetivos:

I - Testemunhar o evangelho de Jesus Cristo na dinâmica da vida institucional.

II - "Confrontar as pessoas com o evangelho e a pessoa de Cristo, oferecendo-Ihes a opção de fé como começo do processo transformador e formador do novo homem e da nova mulher em Cristo"

III - Estimular as pessoas que fazem parte da vida institucional a participarem de uma comunidade de fé como uma forma de viver a graça de Deus e de dar um novo sentido à sua existência.

IV - Participar junto com o Bispo, Conselho Diretor e a Direção Geral da instituição, na implantação das marcas da confessionalidade metodista, mantendo para isto permanente dialogo com os representantes da Igreja acima mencionados.

V - "Confrontar o ser humano e as estruturas sociais com Jesus Cristo e o Reino por Ele proclamado, a fim de que as pessoas e a sociedade o confessem como Senhor, Salvador e Libertador, e as estruturas sejam transformadas segundo o Evangelho." (PVMI, E 2.1.-Cânones, p.103)

$\mathrm{VI}$ - "Libertar a pessoa e a comunidade, através de Cristo, de tudo que as escraviza e conduzi-las à plena comunhão com Deus e o próximo." (PVMI, E 2.2. - Cânones, p.103).

VII - Verificar se as decisões institucionais estão sendo tomadas de acordo com as orientações oficiais da Igreja e, se necessário denunciar ao Bispo da Instituição ou ao $\mathrm{CE}$, praticas que não estão alinhadas com as diretrizes da Igreja Metodista para a área educacional.

VIII - Ajudar as pessoas a tomar consciência dos sinais de vida e de morte no mundo, e se posicionar diante deles.

IX - "Dar continuidade, sob a ação do Espírito Santo, ao processo educativo realizado por Deus em Cristo, que promove a transformação da pessoa em nova criatura e do mundo em novo mundo, na perspectiva do Reino de Deus. 
X - Motivar educadores e educandos a se tornarem agentes positivos de libertação, através de uma prática educativa de acordo com o Evangelho.

$\mathrm{XI}$ - Confrontar, permanentemente, as filosofias vigentes com o Evangelho.

XII - Denunciar todo e qualquer tipo de discriminação e dominação que marginalize a pessoa humana, e anunciar a libertação em Jesus Cristo.

XIII - Respeitar e valorizar a cultura dos participantes do processo educativo, na medida em que estejam de acordo com os valores do Reino de Deus.

XIV - Apoiar os movimentos que visem a libertação dos oprimidos dentro do espírito do Evangelho Libertador de Jesus Cristo."

XV - Despertar a consciência crítica sensibilizada para o problema da injustiça, num mundo marcado pela opressão." (DEIM, IV, itens 1 à 7 ).

Parágrafo Único - Tais objetivos deverão ser expressos claramente no Plano de Ação da Pastoral.

\section{A COMPOSIÇÃO E FUNCIONAMENTO DA PASTORAL}

Art. 4ํ - A Pastoral, nas instituições da Área Geral, está subordinada ao Colégio Episcopal (Cânones, Art. $91 \S 1^{\circ}$ ) através do Bispo da mesma. Nas instituições regionais a Pastoral está subordinada ao Bispo da respectiva Região (Art 97, IX).

Art. 5o - A equipe da Pastoral é constituída por clérigos/as e leigos, que exercem diferentes funções, de acordo com seu regimento interno.

$\S 1^{\circ}$-: No caso dos/das clérigos/as, a nomeação leva em conta o regime de itinerância e a regulamentação aprovada pelo CE. ( Art. $23 \S 2^{\circ}$ e 4ํ; ; Art. 63 - XVIII)

$\S 2^{\circ}$ - No caso dos/das leigos/as, a designação é feita pelo/a bispo/a e a contratação feita pela instituição, seguindo as normas da mesma.

Art.6ㅇ - O/A Coordenador/a da Pastoral nas instituições da Área Geral é nomeado/a pelo Colégio Episcopal (Cânones Art. 63 - XVIII). Nas instituições da Área Regional a nomeação do/a Coordenador/a é de responsabilidade do Bispo ou Bispa Presidente do respectivo Concílio (Cânones, Art.97, IX), seguindo a normatização regional, respeitada a legislação canônica.

Art.7ํ - O Bispo/a da instituição, juntamente com o Colégio Episcopal, ouvido o/a coordenador/a da pastoral e a direção geral, escolhe os demais membros da equipe para as diferentes funções da Pastoral Escolar ou Universitária (Art.159). O mesmo procedimento é adotado em caso de desligamentos.

Parágrafo único: A coordenação da pastoral, de acordo com o regimento interno,e após ouvir o bispo da instituição, define as funções para os diferentes membros da equipe. 
Art. $8^{\circ}$ - Em caso de clérigo/a a escolha e cedência é encaminhada junto ao/à Bispo ou Bispa da respectiva Região e ao Colégio Episcopal, antes da nomeação.

Art.9 - O Bispo respectivo, após dialogo com a direção da instituição e de acordo com as orientações do CE, define o regime de trabalho, parcial ou integral, as condições contratuais e o numero de pessoas que compõe a equipe da Pastoral, levando em consideração se é escolar ou universitária.

Parágrafo Único - Os membros clérigos da pastoral nomeados em tempo integral podem solicitar ao/à Bispo/a da Instituição e ao Conselho Diretor (Art. 23 § 9ㅇ) autorização para estudos vinculados à ação pastoral após dois anos completos de sua nomeação ou designação.

Art.10 - O Plano de Ação da Pastoral é elaborado pela sua equipe, em diálogo com as diversas áreas da instituição, e encaminhado pelo/a Coordenador/a ao Bispo ou Bispa da instituição que, depois de aprová-lo, o encaminha à instituição para que seja integrado ao seu plano de Ação.

Art.11 - O Bispo ou Bispa da instituição é responsável pelo processo de avaliação do trabalho da pastoral, inclusive do desempenho dos membros da equipe.

Art.12 - A avaliação da Pastoral se dá através de instrumentos do Colégio Episcopal, à luz do Plano de Ação da Pastoral, envolvendo a Direção Geral, os diversos segmentos da Instituição e a própria Pastoral.

Art.13 - As Pastorais se constituem em Coordenação Nacional das Pastorais Escolares e Universitárias - CONAPEU, regida por regimento próprio aprovado pelo Colégio Episcopal.

Art. 14 - Os/As clérigos/as nomeados/as para uma Pastoral Escolar e Universitária também recebem uma nomeação para uma Igreja Local, preferencialmente onde a instituição está localizada.

$\S 1^{\circ}$ - Se a nomeação para a instituição for de tempo integral, a nomeação para a Igreja Local será de tempo parcial e sem ônus.

$\S 2^{\circ}$ - Se a nomeação para a instituição for de tempo parcial, a nomeação para a Igreja Local também será de tempo parcial.

$\S 3^{\circ}$ - No caso expresso no parágrafo $2^{\circ}$, a questão do ônus é definida na nomeação.

$\S 4^{\circ}$ - No Plano de Ação da Pastoral Escolar e Universitária deve constar a forma com os/as clérigos/as terão o dia de descanso.

§ $5^{\circ}$ - Ao/à clérigo/a nomeado/a para uma instituição com tempo integral é garantido o dia de descanso, na forma estabelecida no Plano de Ação Pastoral (do/a Pastor/a) aprovado pelo Bispo da Instituição e Igreja Local. 


\section{A PASTORAL E O ENSINO RELIGIOSO}

Art.15 - Ensino Religioso é componente obrigatório dos currículos das escolas Metodistas. Encontra seu amparo legal nos documentos oficiais da Igreja Metodista, pautados na tradição de respeito às outras tradições religiosas dos participantes de nosso processo educativo, contribuindo para a formação integral dos alunos e alunas das nossas instituições, visando prepará-los para o pleno exercício de uma cidadania responsável, na perspectiva de uma ética comprometida com a dignidade de vida.

Art.16 - O ensino religioso, como uma das marcas de nossa confessionalidade e como parte do processo pedagógico, é de responsabilidade da Pastoral na Educação Infantil, Ensino Fundamental e Ensino Médio; é construído a partir das ênfases estabelecidas pela Igreja. No caso do Ensino Superior é de responsabilidade da instância competente, garantindo-se a participação da Pastoral neste processo.

Art.17 - O Ensino Religioso deve estar integrado organicamente ao projeto político pedagógico e administrativo da Instituição Escolar e Universitária, em seus valores e práticas priorizados em programas de ação comunitária. A nomenclatura para designação desta disciplina, nas instituições de Ensino Superior, é diversa, garantida a filosofia confessional das IMEs.

Art.18 - O ensino religioso é ministrado de acordo com a organização pedagógica da instituição em todos os níveis (Infantil, Fundamental, Médio e Superior).

Art.19 - Cabe à Pastoral, em diálogo com o setor pedagógico e direção, selecionar os/as professores de ensino religioso para a Educação Infantil, Ensino Fundamental, Ensino Médio e Superior, de acordo com os critérios de formação específica na área (conforme as exigências da LDB), conhecimentos teológico-pastorais, estabelecidos por critérios pastorais e pedagógicos pela Pastoral e pela área pedagógica da instituição, respectivamente. No caso da Universidade, o critério de contratação é estabelecido pela Instituição, garantindo a filosofia confessional das IMEs.

Art.20 - O perfil do/a docente é traçado segundo critérios de formação específica para o Ensino Religioso nas Instituições Metodistas de Educação, e expressa um claro compromisso com a tradição cristã mais ampla e com a centralidade do Reino de Deus. No caso da educação básica, todos devem ser metodistas.

\section{A PASTORAL E ORÇAMENTO DA INSTITUIÇÃO}

Art.21 - A Pastoral deve ser contemplada no Orçamento Programa da instituição com recursos necessários ao desenvolvimento do seu Plano de Ação aprovado pelo Bispo ou Bispa da instituição e encaminhado ao Conselho Diretor e Direção. 
Art.22 - Os Conselhos Diretores e Direções Gerais devem oferecer a necessária infraestrutura,através de recursos, abertura de espaço e o demais necessário para o efetivo desempenho da Pastoral.

O presente Regulamento somente poderá ser modificado, alterado ou complementado pelo Colégio Episcopal da Igreja Metodista. Entra em vigor na data infra, e revogam-se as disposições em contrário.

São Paulo, 03 de março de 2009.

Bispo João Carlos Lopes Presidente do Colégio Episcopal

Bispo Adonias Pereira do Lago Secretário do Colégio Episcopal 